فاعلية استراتيجية التفكير بصوت مرتفع في تنمية التفكير التأملي والتحصيل

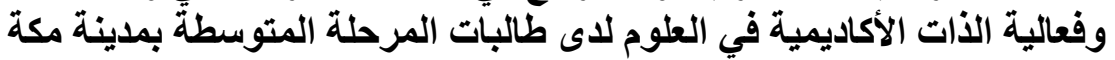
المكرمة لأب طات

أعداد:د/ هدى بنت محمد حسين بابطين*

المقدمة:

يشهد القرن الحادي والعشرون تطوراً سريعاً في شتى مجالات الحياة القئ نتيجة

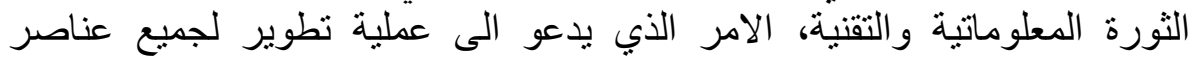

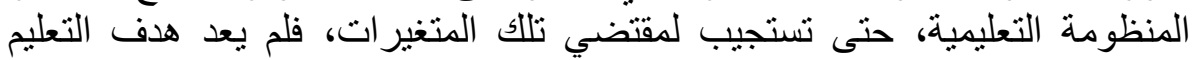

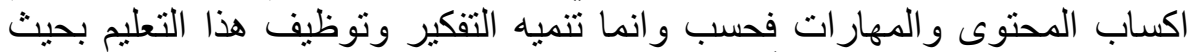
يُمكن الفرد من ان يتعلم معتمداً على نفسه أيا كان ما يريد معرفئه.

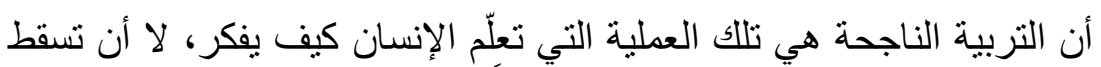

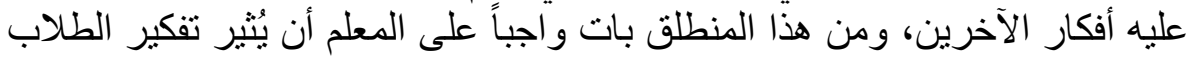

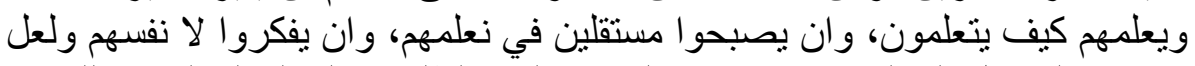

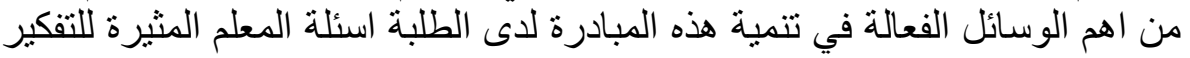

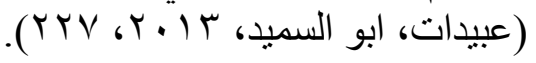

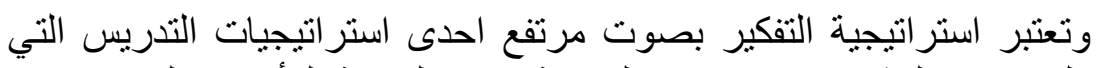

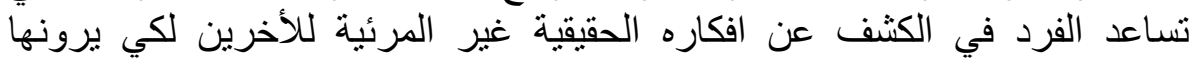

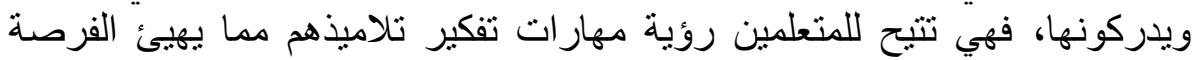

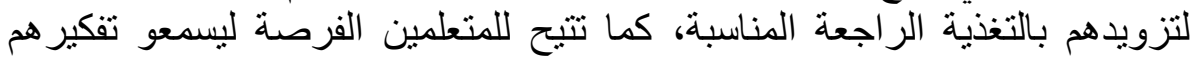

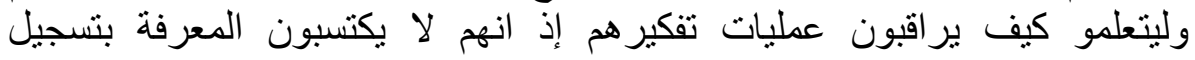

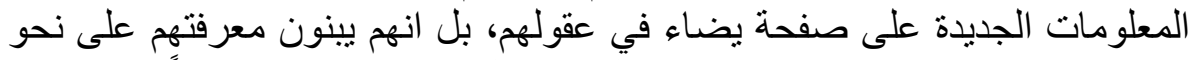

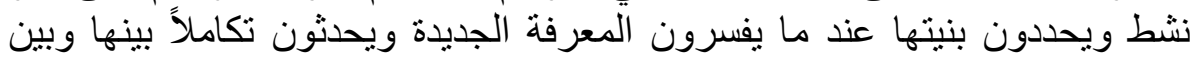

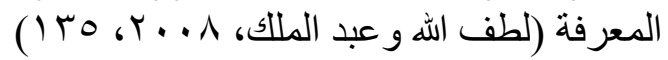

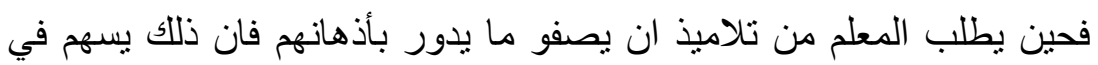

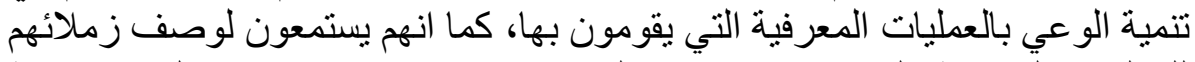

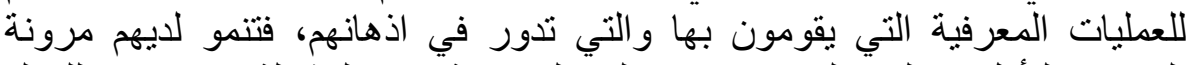

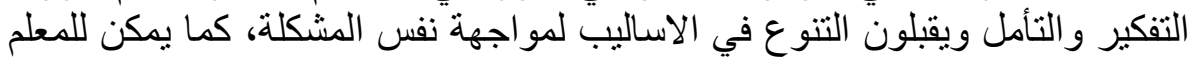

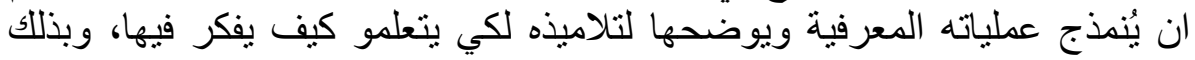

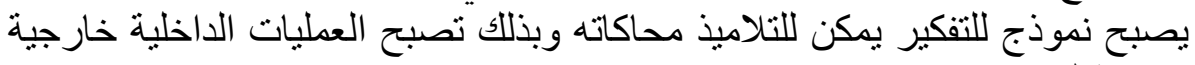

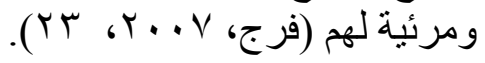

* أستاذ المناهج وطرق تدريس العلوم الششارك بجامعة أم القرى 


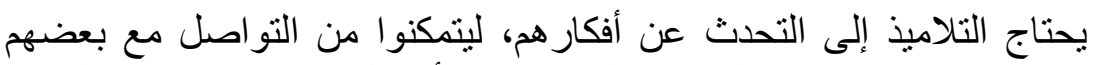

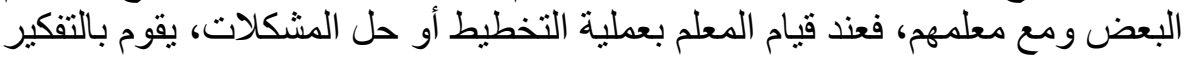

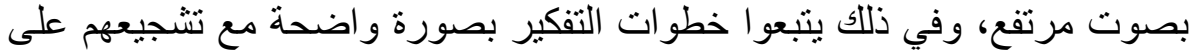

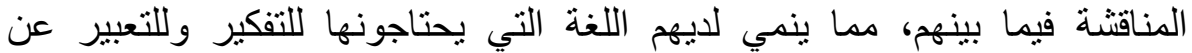

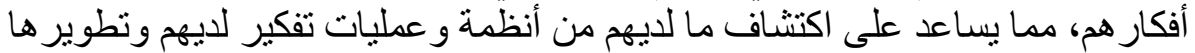

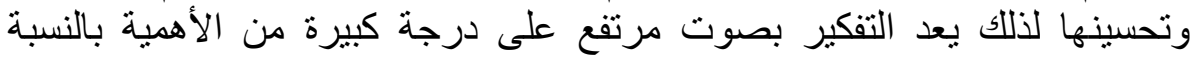

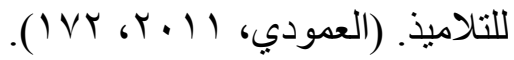

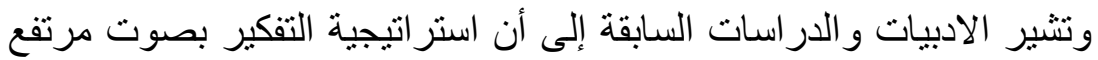

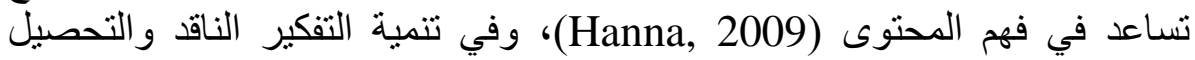

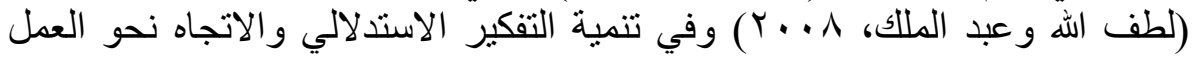

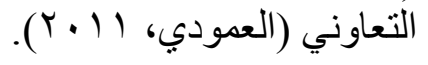

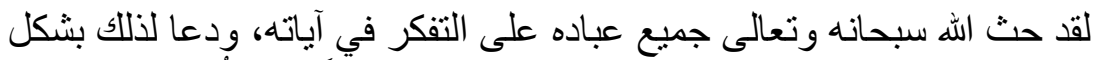

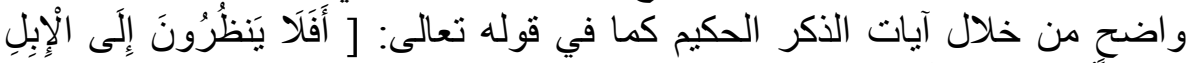

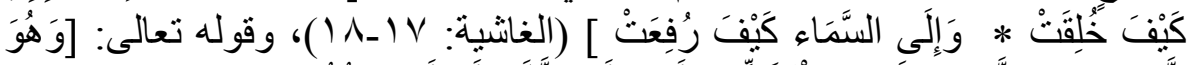

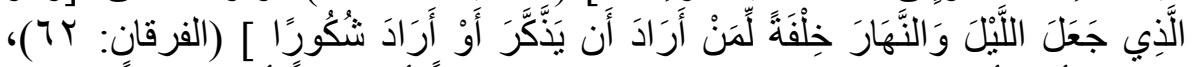

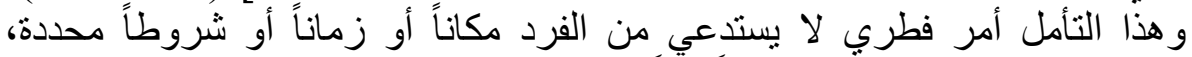

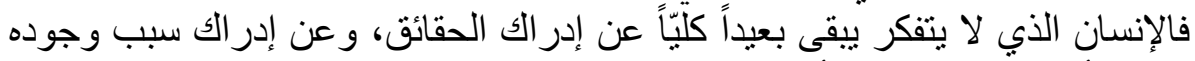

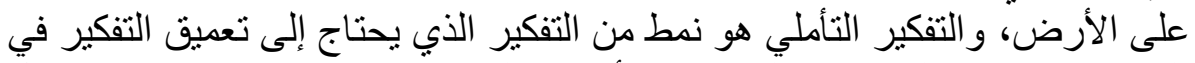

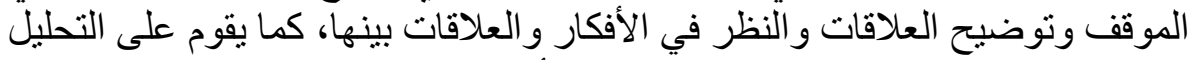

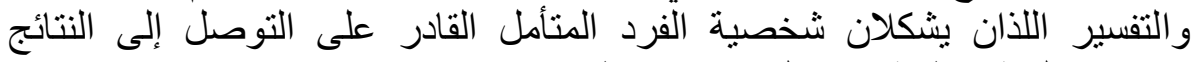

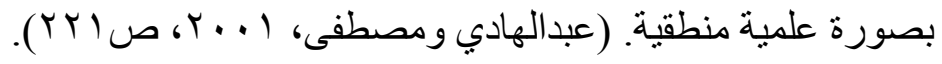

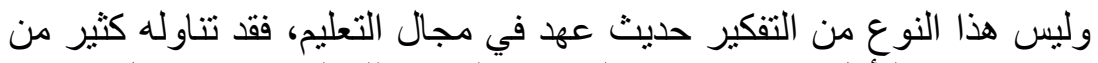

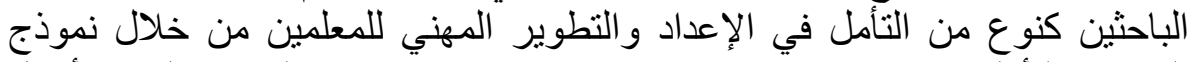

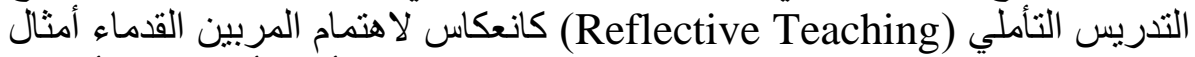

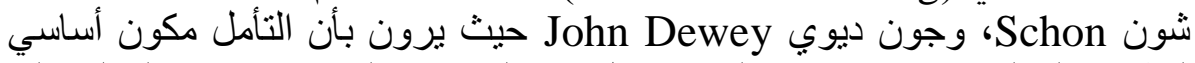

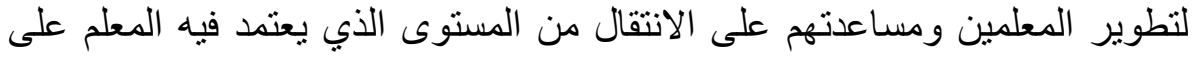

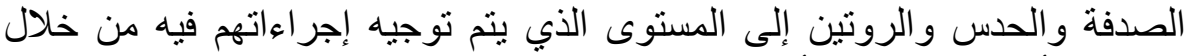

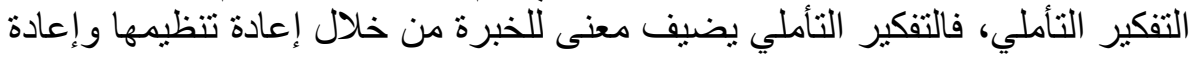
بنائها (Basol \& Gencal, 2013).

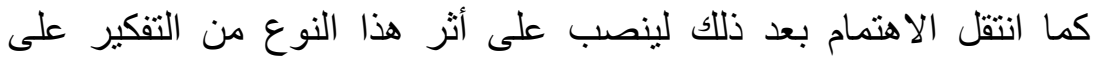

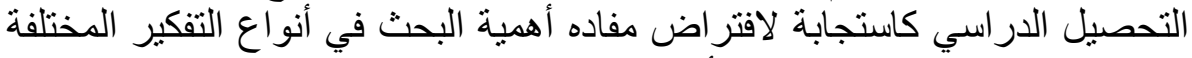

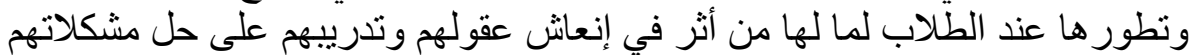
وتدبر أمور حياتهم وزيادة تحصيلهم المعرفي. في أنعائ 
وقد تناول بعض الباحثين دراسة هذا النوع من التفكير وتتميته لدى الطلاب

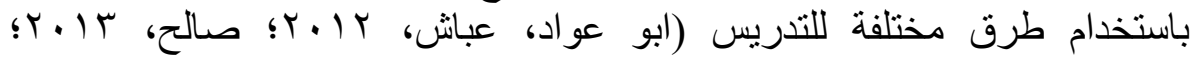

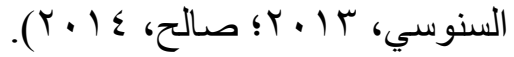

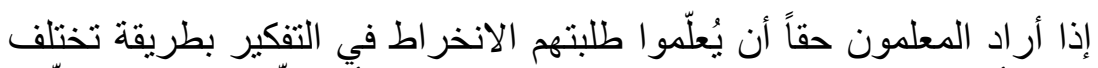

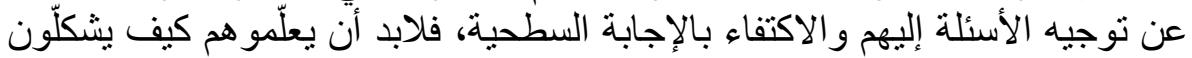

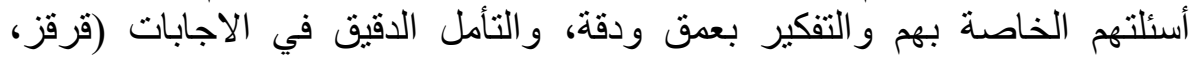
. (Or r. T E

كما أن الأسئلة والمناقثة الصفية بصوت مرتفع تثير تفكير التلاميذ وتنمي

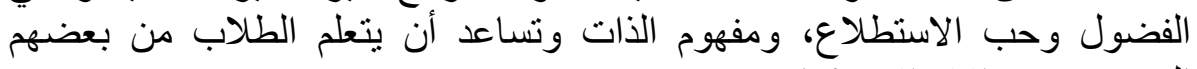

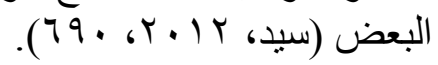

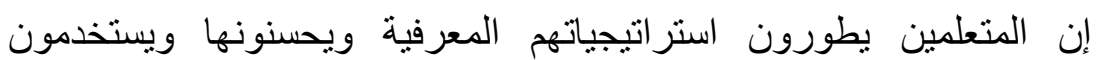

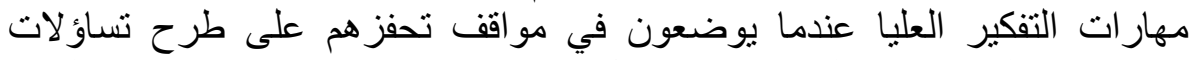

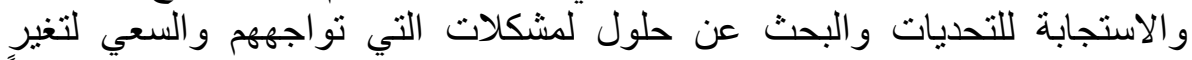

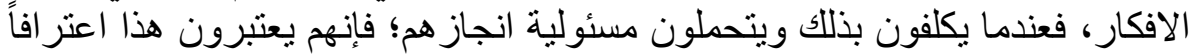

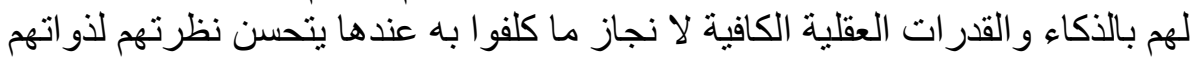

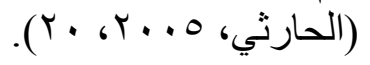

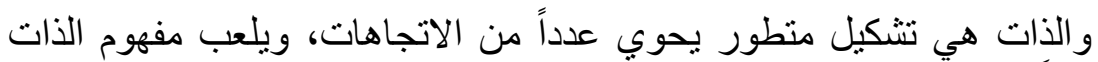

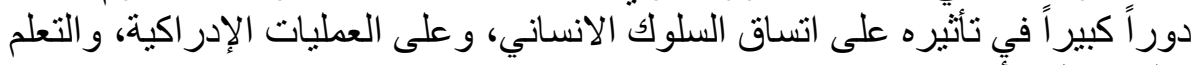

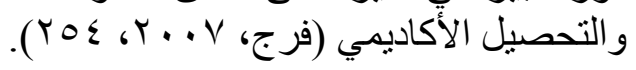

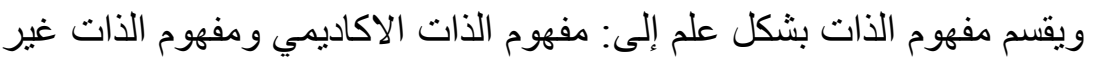

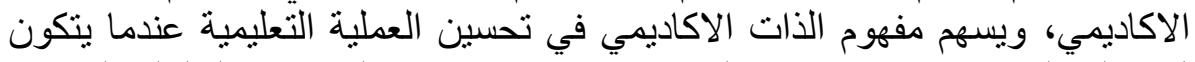

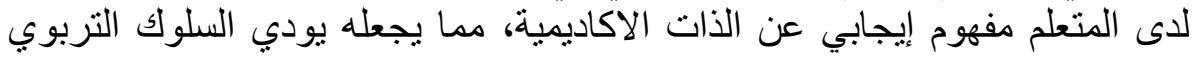

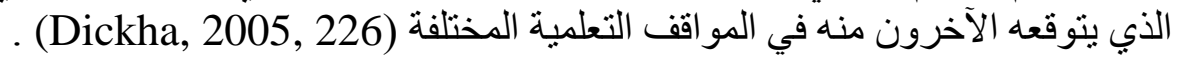

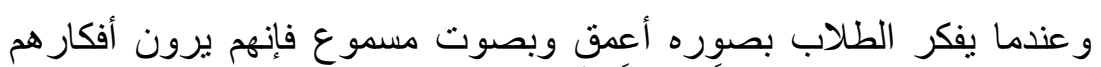

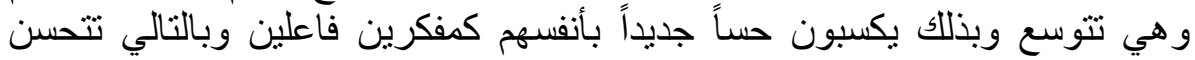

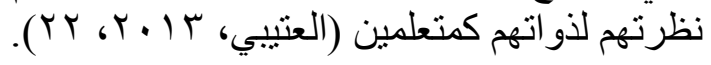

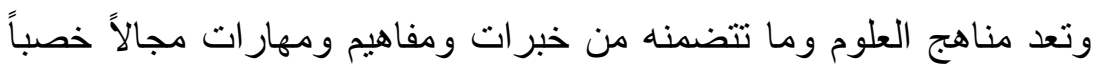

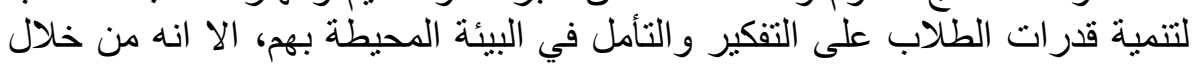

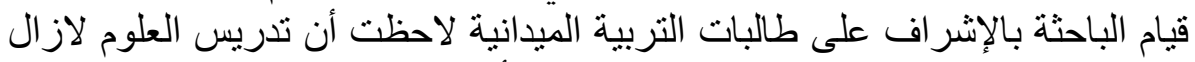

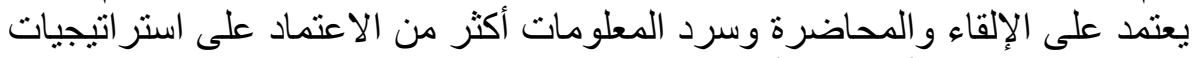

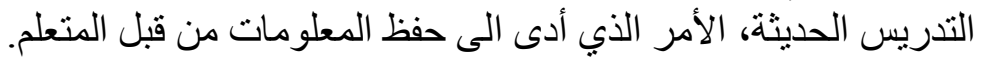

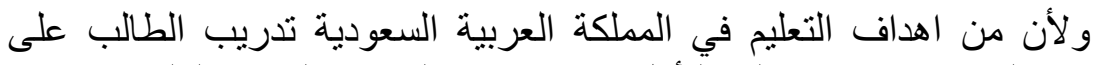

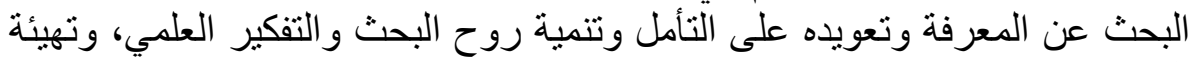
الفرص لتوظيف المعلومة في المو اقف الحياتية. 


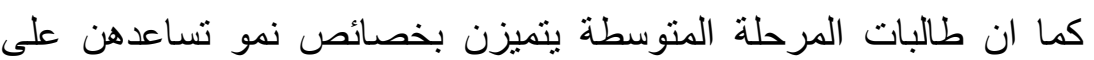

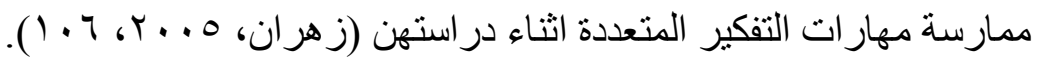

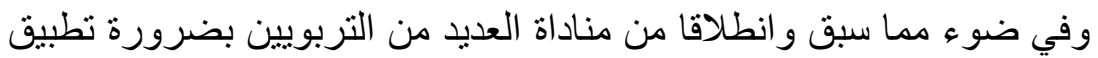

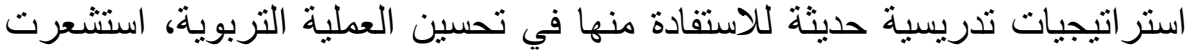

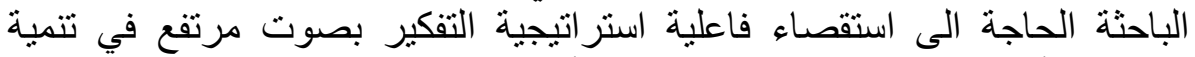

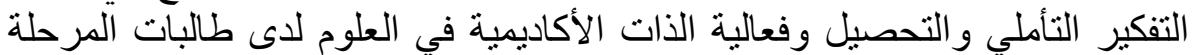
المتوسطة بمدينة مكة المكرمة.

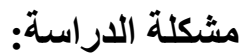

بالرغم من التغيرات التي طرأت على محتوى مناهج العلوم في المرحلة

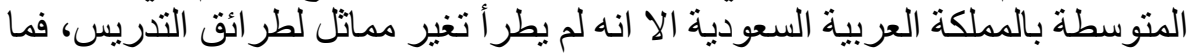

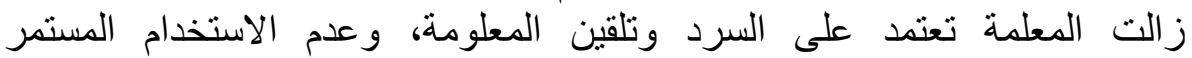

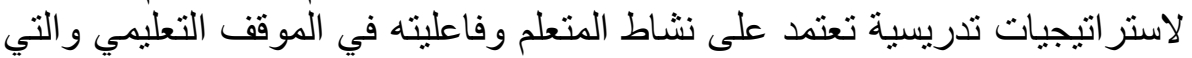

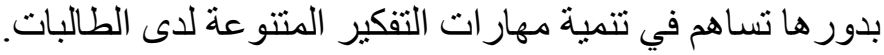

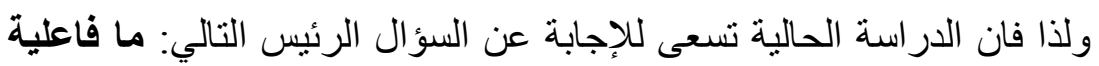

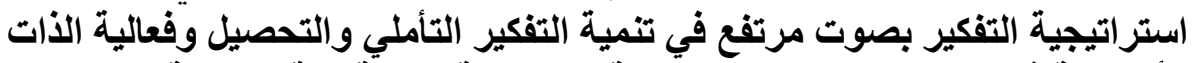

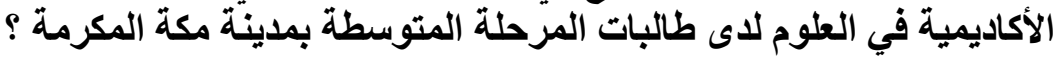
ويتفرع من هذا السؤال الأسئلة التالية:

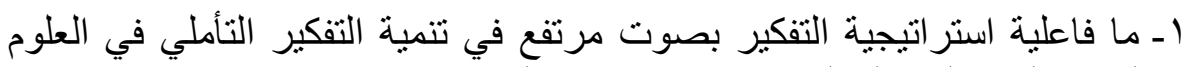
لاى طالبات المرحلة المتوسطة بمدينة مكة المكرمة فئج

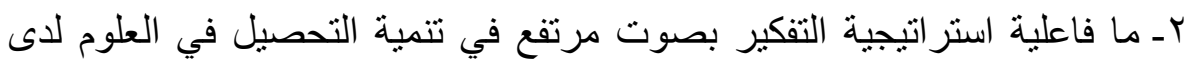

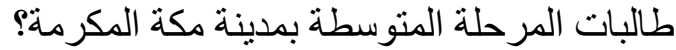

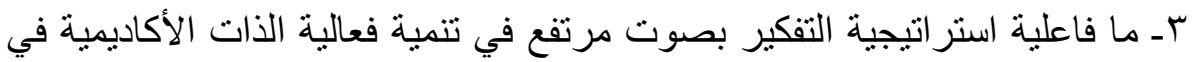
العلوم لاى طالبات المرحلة المتوسطة بمدينة مكة المكرمة؟ فئج

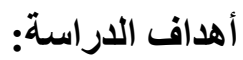

$$
\text { هدف البحث الحالي إلى التعرف على: }
$$

ا ـ فاعلية استراتيجية التفكير بصوت مرتفع في تنمية التفكير التأملي لدى طالبات المرحلة المتوسطة بمدينة مكة المكرمة.

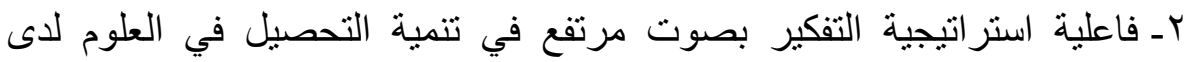
طالبات المرحلة المتوسطة بمدينة مكة المكرمة.

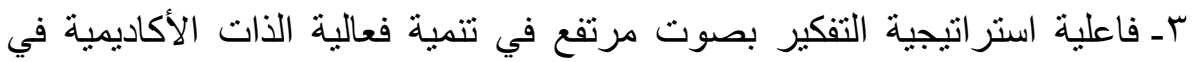
العلوم لدى طالبات المرحلة المتوسطة بمدينة مكة المكرمة. 


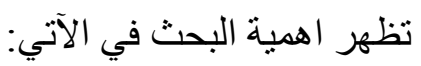

1 ـ يعد البحث استجابة للاتجاهات الحديثة التي تنادي بضرورة الفياتية تنمية التفكير التأملي

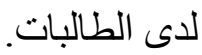

r ـ قد يسهم البحث في توجيه القائمين بعملية بناء مناهج العلوم وتطوير ها من خلال

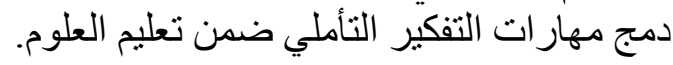

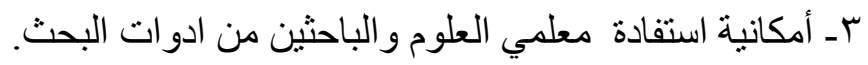

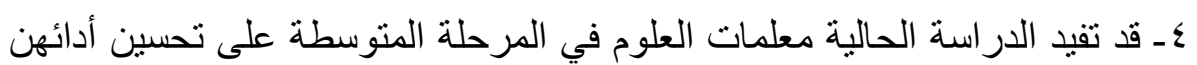

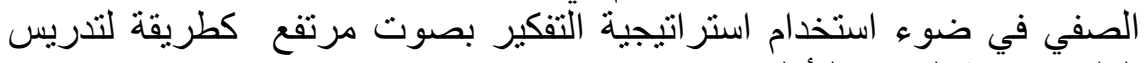
العلوم وتنمية التفكير التأملي.

$$
\text { حدود الاراسة: }
$$

اقتصرت الدر اسة الحالية على الحدود التالية:

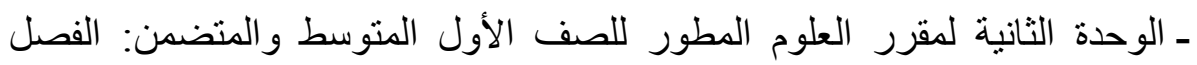

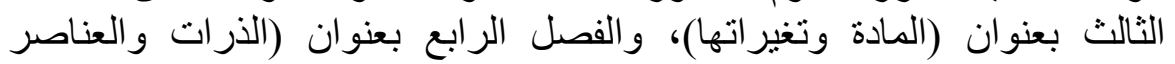
و الجدول الدوري).

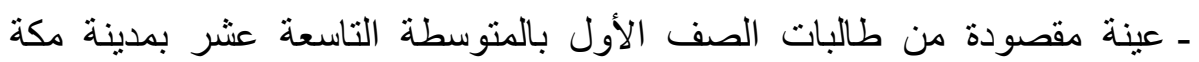

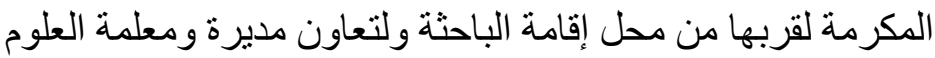

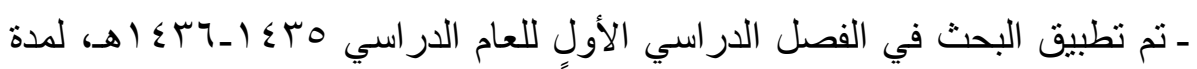

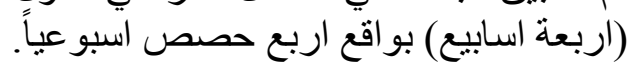

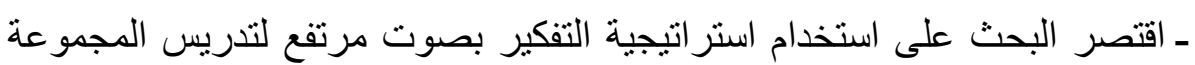
التجريبية، و التدريس بالطريقة المعتادة للمجمو عة الضابطة.

ـ تم تطبيق أدوات الدر اسة التالية:

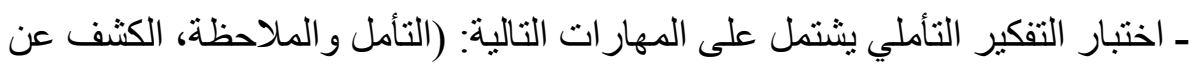

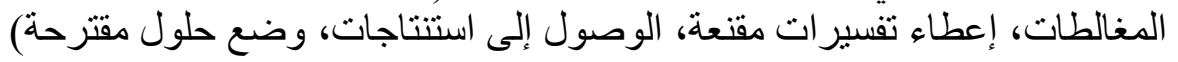

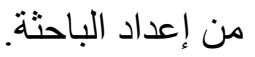
ـ ـ إعداد اختبار تحصيلي يقيس المستويات (التذكر ، الفهم، التطبيق) من إعداد الباحثة. ـ إعداد مقياس يقيس فعالية الذات الأكاديمية في العلوم من إعداد الباحثة. 


\section{الفاعلية Effectiveness:}

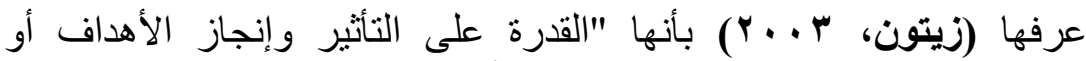

$$
\text { المدخلات لبلوغ النتائج المرجوة و الوصون بانهول إليها بأقصى حد ممكن". }
$$

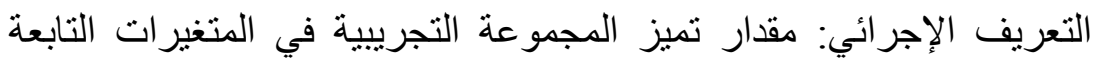

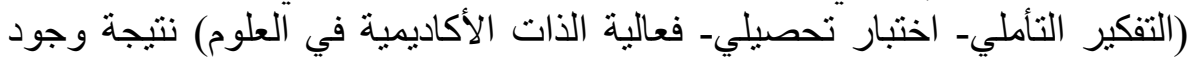

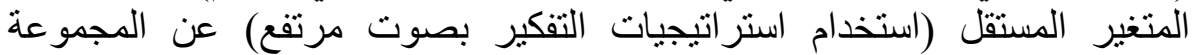

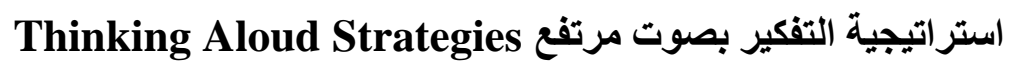

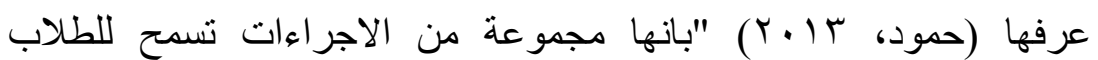

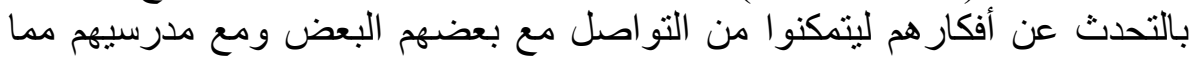

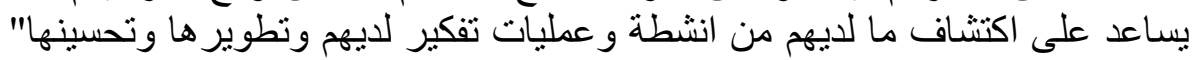

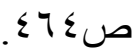

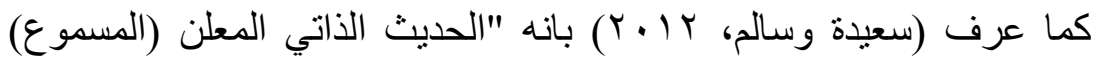

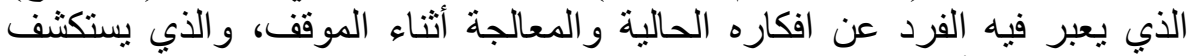

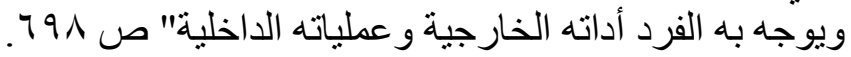

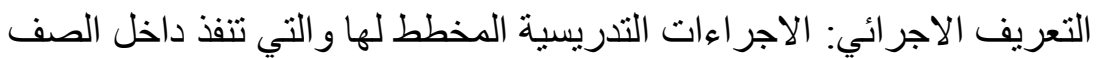

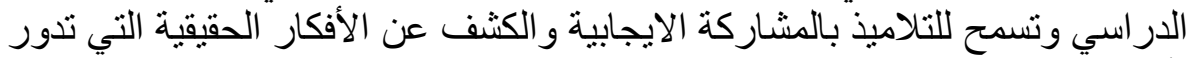

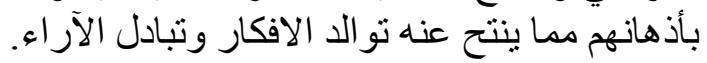

\section{التفكير التأملي Reflective Thinking:}

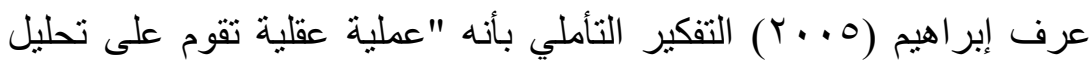

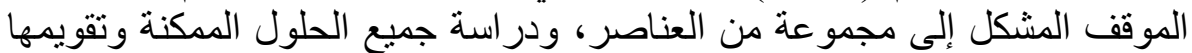

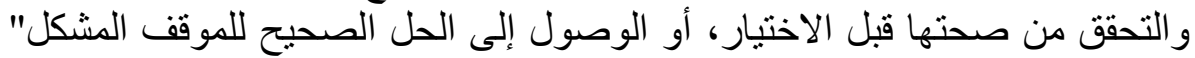
.

كما عرفه سعادة (1 . . † ) "بانه ذللك النمط من التفكير المرتب بالوعي الذاتي

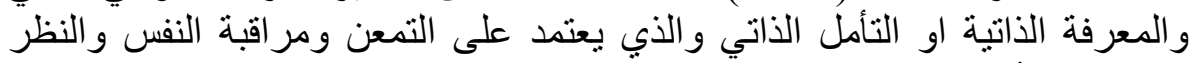

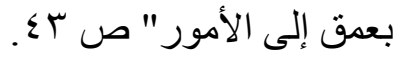

التعريف الاجرائي: بأنه التفكير المتعمق في المواقف، والأني والذي يكسب التلميذة

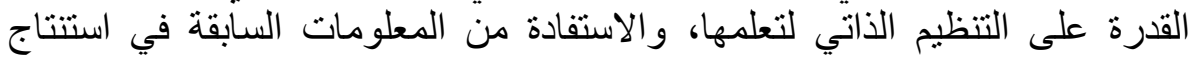

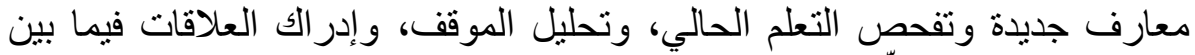

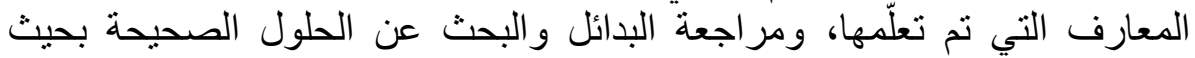
تصبح التلميذة منتجة للمعرفة، ويقاس برالدة البرجات التي تحصل عليها التلميذة في اختبار 


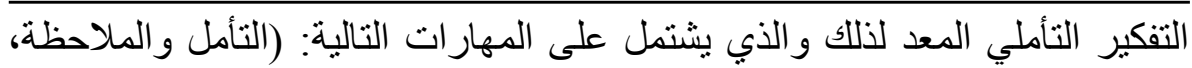

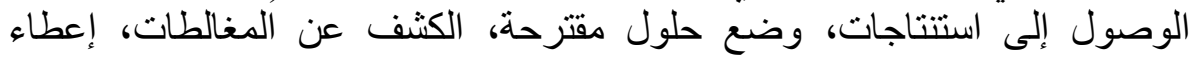
تفسير ات مقنعة)

فعالية الات الاكاديمية في العلوم Academic Self- Efficacy in

:Science

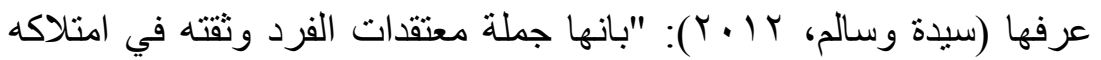

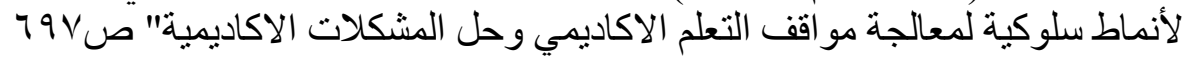

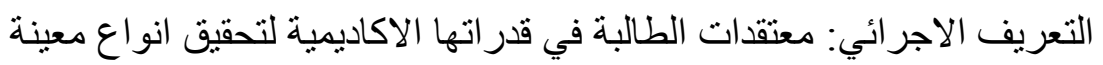

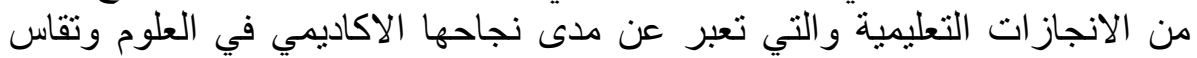
بالدرجة التي تحصل عليها في مقياس فعالية الذات الاكاديمية في العلوم المعد من فبل الباحثة.

\section{التحصيل الاراسي: Achievement}

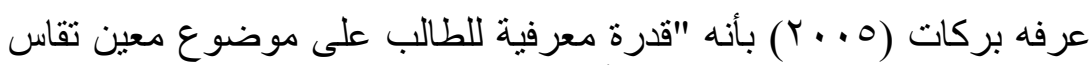

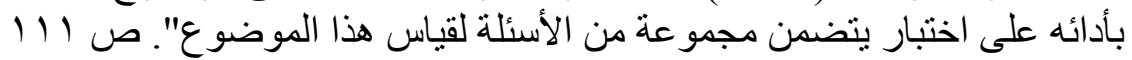

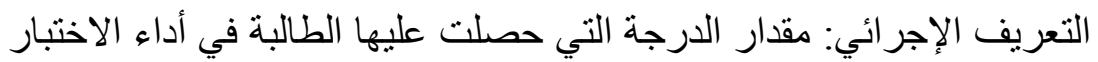

التحصيلي المعد من قبل الباحثة عند المستويات المختلفة (التذكر ـ الفهم- التطبيق).

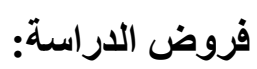
في ضوء نتائج الدراسات السابقة هدف البحث الحالي إلى اختبار صحة

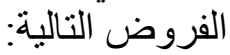

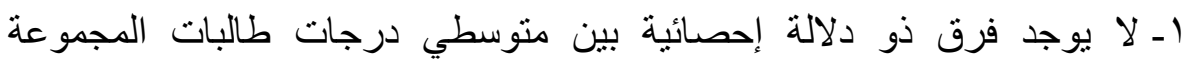
التجريبية والمجموعة الضابطة في اختبار التفكير التأملي الكلي البعدي ومهار التهات الته المختلفة . - النجة

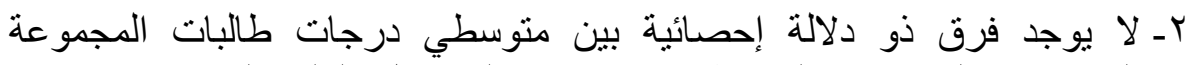
التجرييية والمجموعة الضابطة في اختبار التحصيل الكلي البعدي دئي ومستوياته المختلفة.

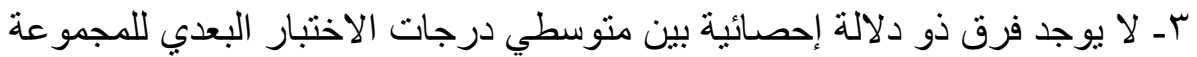

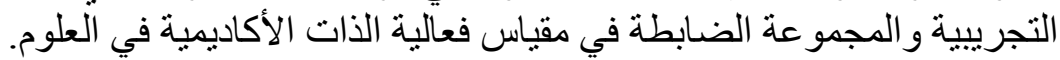

$$
\text { أدبيات الدراسة: }
$$

\section{اولاً: استراتيجية التفكير بصوت مرتفع Thinking Aloud Strategies}

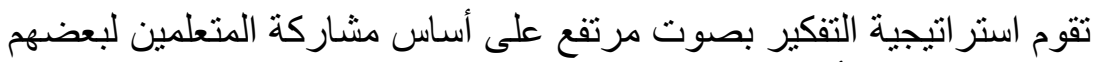

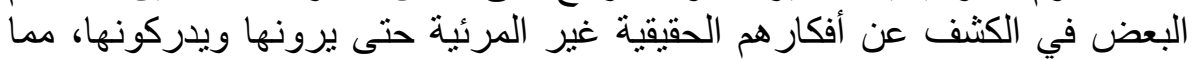
يزود المتعلمين بفرص لمر اقبة عملياتهم التكفيرية، و أثناء ذلك يتم بناء معرفتهم على لئى 
نحو نشط ويشاركونها ويحددون بنيتها ويفسرون فيه المعرفة الجديدة ويحدثون تكاملاً

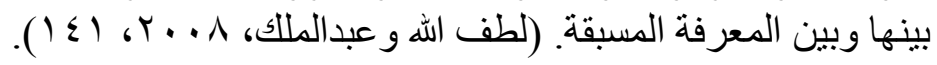

استر اتيجية التفكير بصوت مرتفع يطلب فيها من التلاميذ أن يتكلمو ا ويتناقتوا

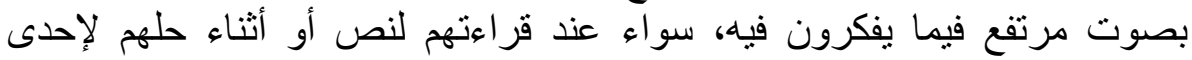

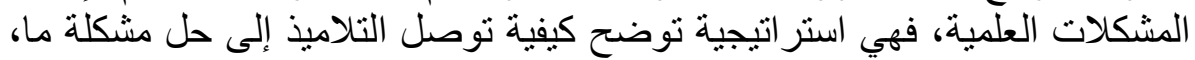

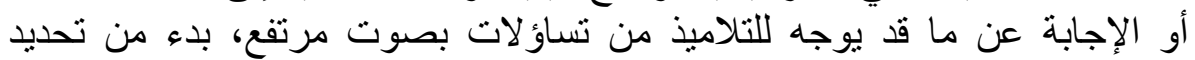

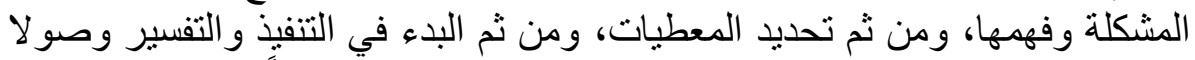

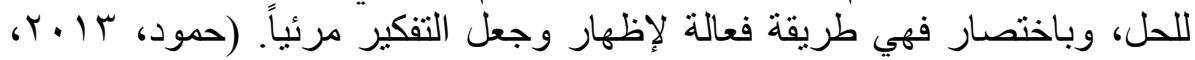

وتعتمد استر اتيجية التفكير بصوت مرتفع أساساً على الأسئلة التي يوجهها

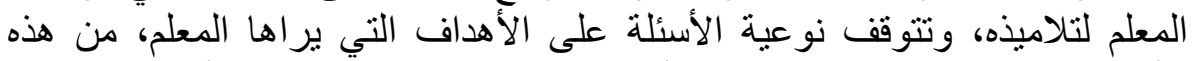

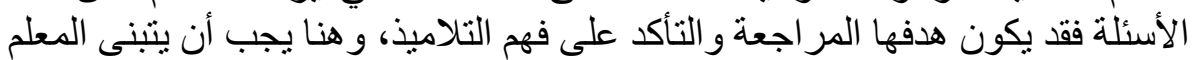

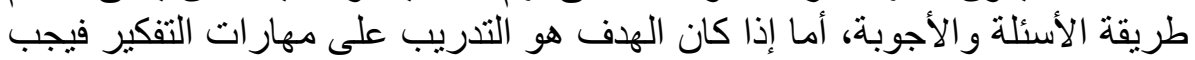

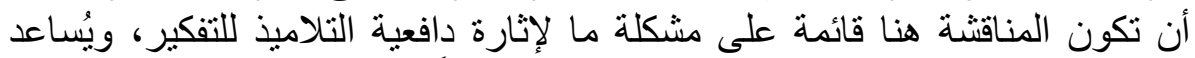

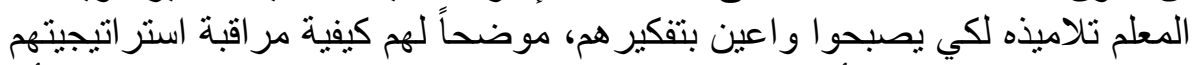

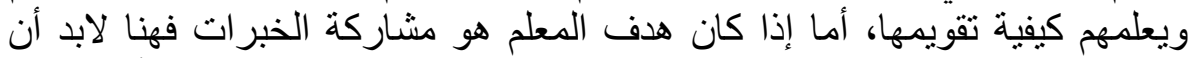

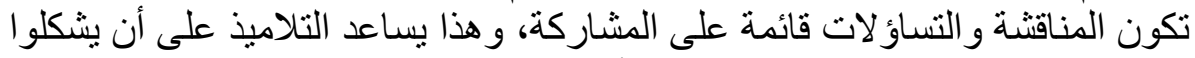

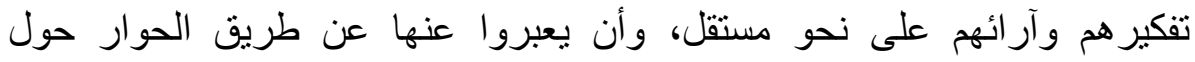

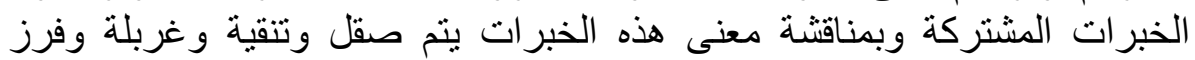

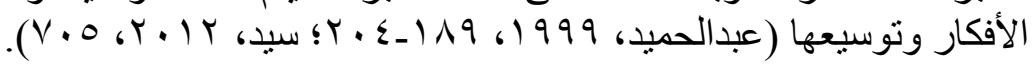

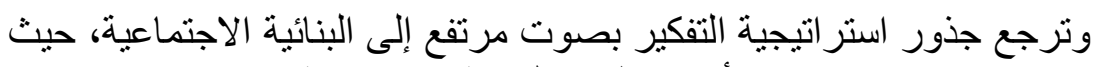

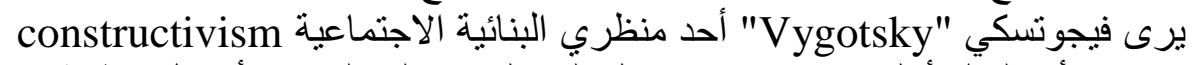
social

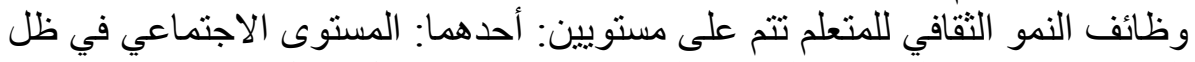

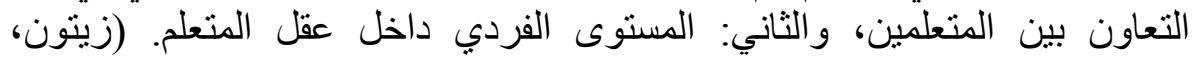

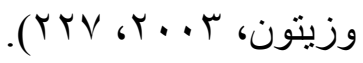

\section{الأسس التي تقوم عليها استر اتيجية التفكير بصوت مرتفع:}

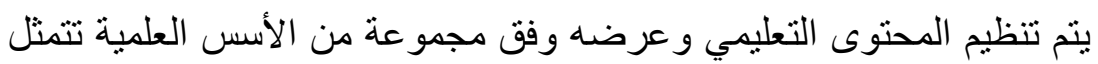

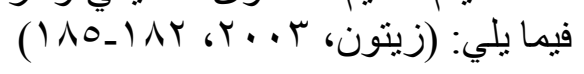

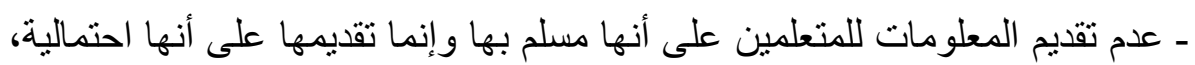

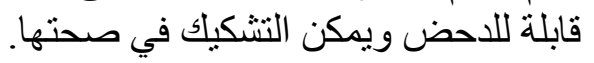

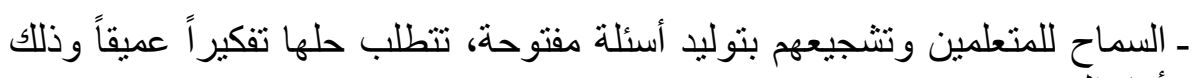
أمام الصفح. ـ استخدام الوسائل التعليمية المثيرة للتفكير. 


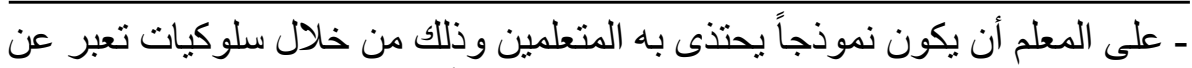

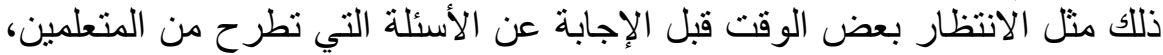

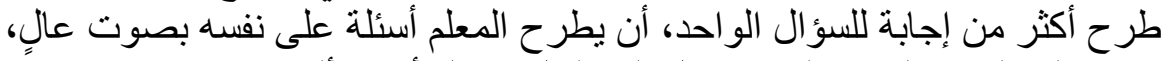

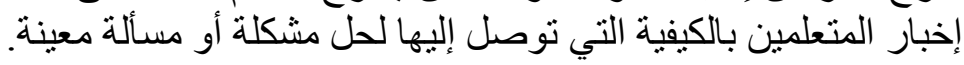

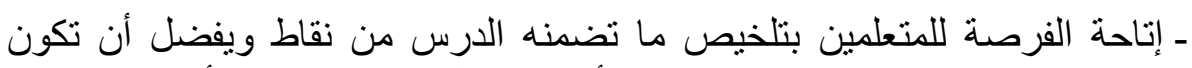
صياغتهم للملخص في صورة مخطط، أو في شكل خريطة مفاهيم أو رسم لتهن تنابعي

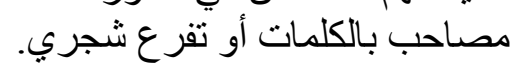

\section{واستراتيجية التفكير بصوت مرتفع يتم توظيفها في الدراسة الحالية:}

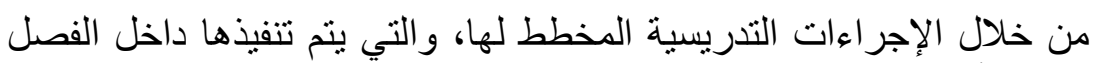

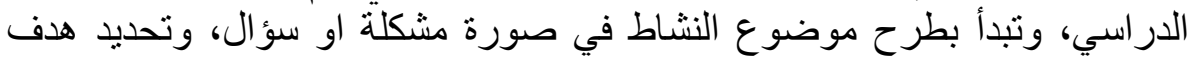

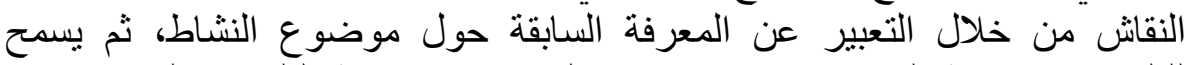

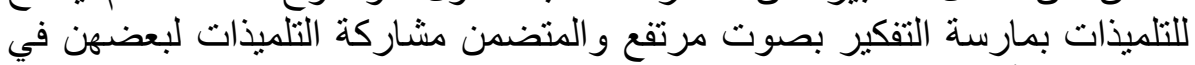

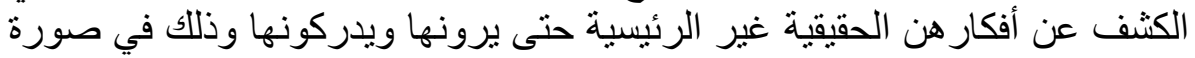

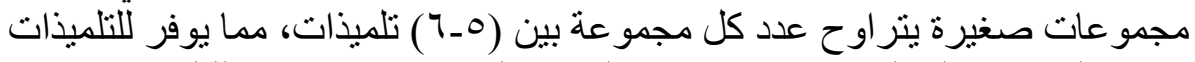

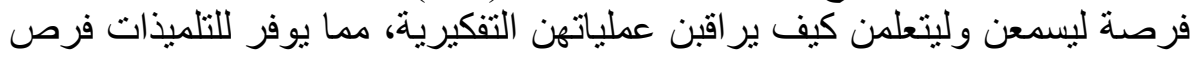

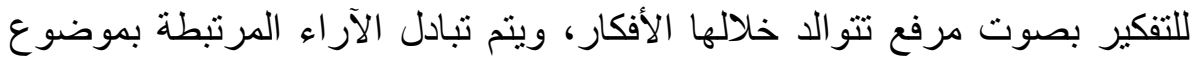

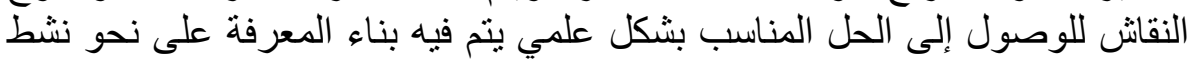

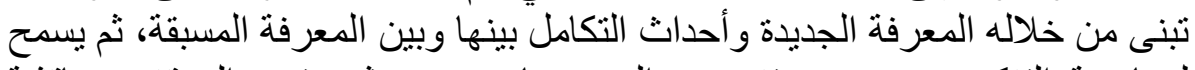

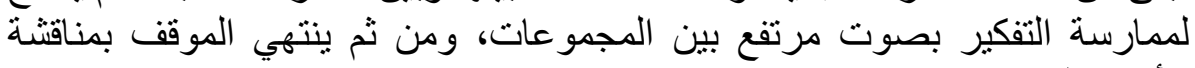
الأفكار المقدمة ومر اجعتها.

\section{مزايا استر اتيجية التفكير بصوت مرتفع:}

Kathryn, ) تساهم استراتيجية التفكير بصوت مرتفع في تحقيق الآتئي

ـ تتمية القدرة على التخطيط لأداء المهمة، وتوجيه الأسئلة، و الاندماج مع الجماعة. ـ تنمية القدرة على مناقثة الصعوبات و المشكلات التي تعترض التلاميذ أثناء القيام

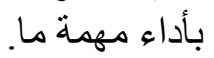

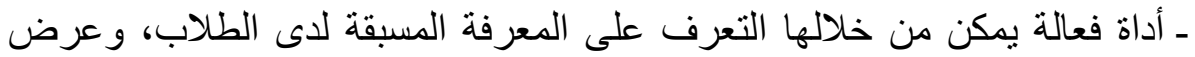
و إبراز عمليات الفهم أثناء القراءة لنص معين، وكذللك التعرف على النى نقاط القوة و والضعف لدى الطلاب.

ـ تساعد في تنمية التفكير الاستدلالي، وتوليد الأسئلة و المعارف والمعلومات، و الدافع الذاتي للتعلم لاعى التلاميذ.

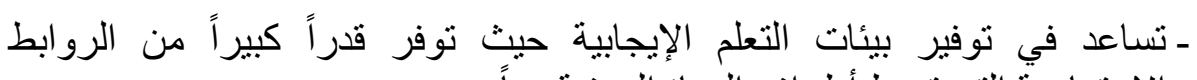
الاجتماعية التي تربط أطر اف الحياة الصفية معاً. 


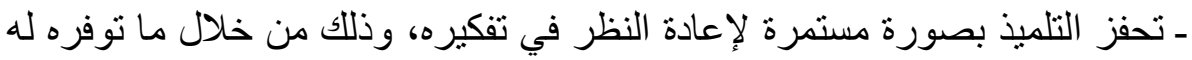
هذه الاستر اتيجية من تغذية راجعة من قبل المعلم و الزملاء. لأناء.

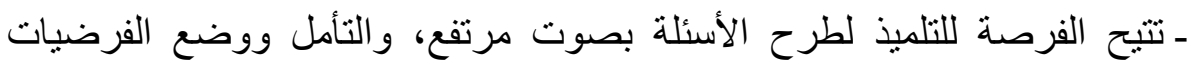

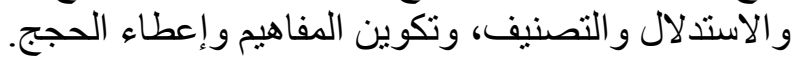

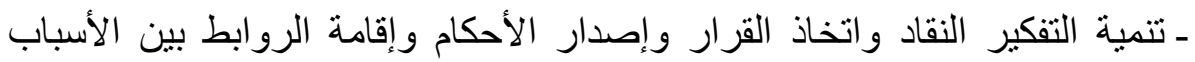
و النتائج.

ـ التعبير الذاتي عن الأفكار للآخرين مما يزيد من ثقة الفرد في الوصول إلى حل

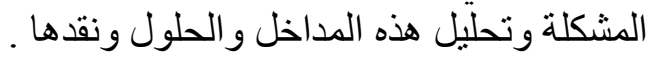

ومن الدراسات التي تناولت استراتيجية التفكير بصوت مرتون ولفع

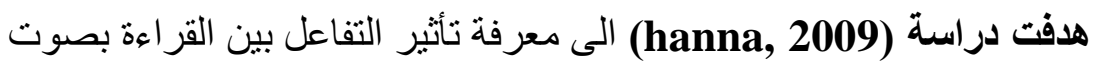

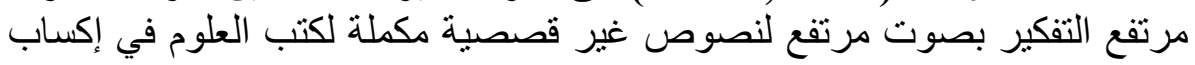

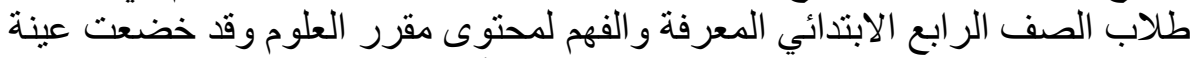

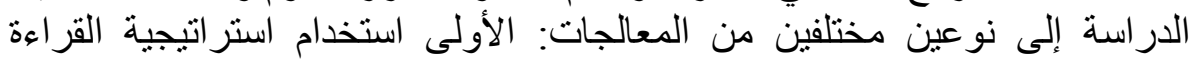

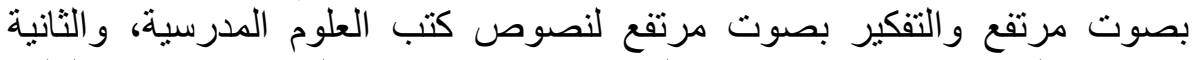

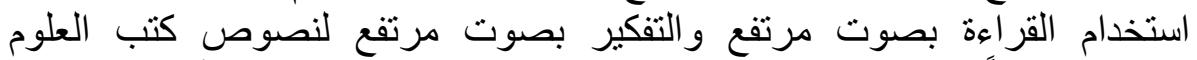

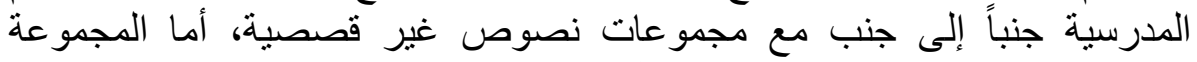
الضابطة فقد اعتمدت على خطط الدروس المعتادة باستخدام القراءة الصامة الصامتة

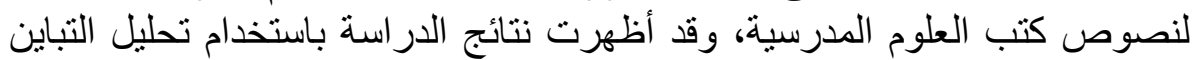

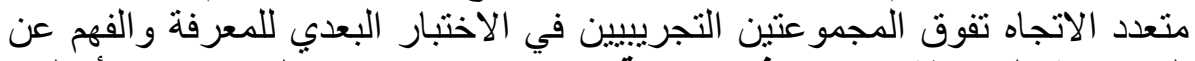

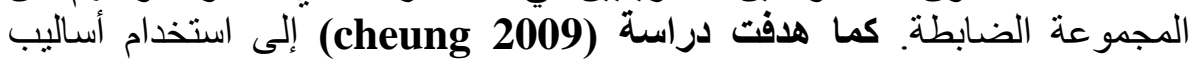

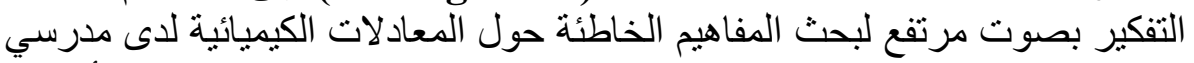

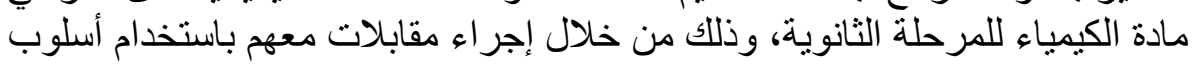

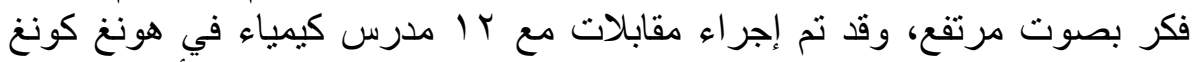

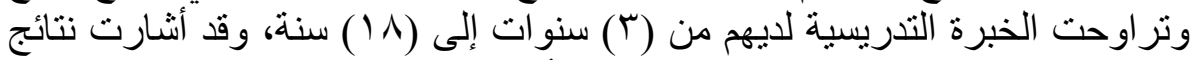

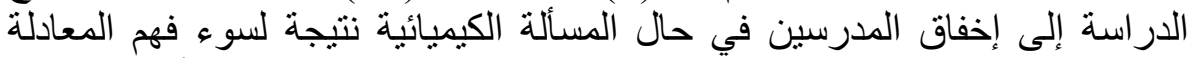

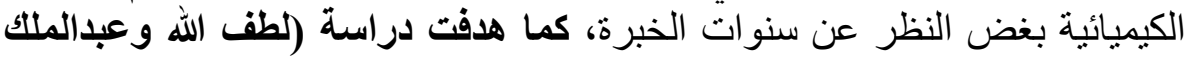

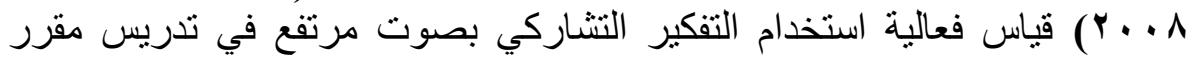

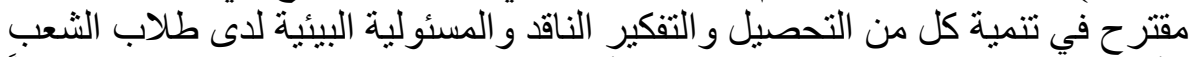

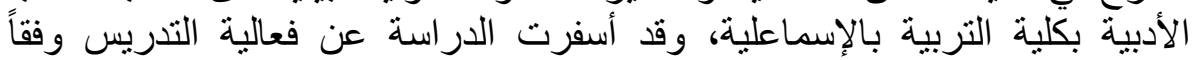

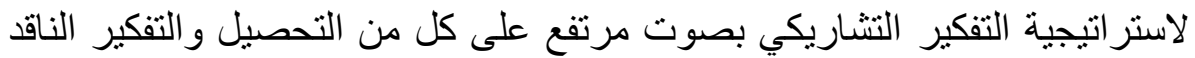

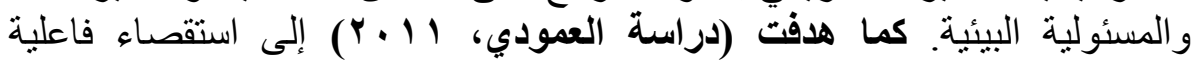

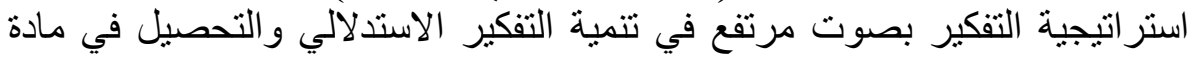

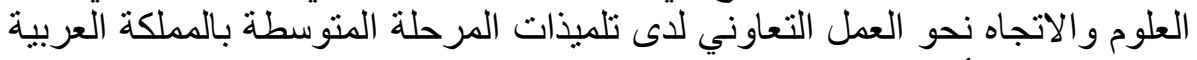

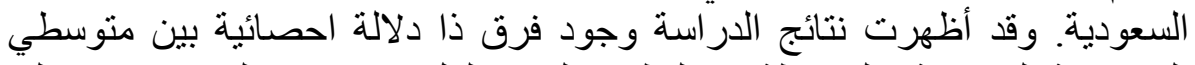
المجموعة التجريبية و الضابطة في التطبيق البعدي لكل من اختبار التفكير الاستدلالي دلي دلي 


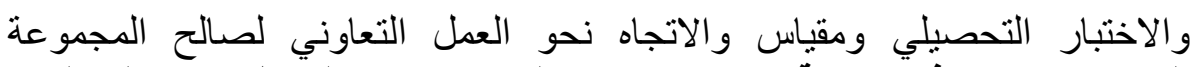

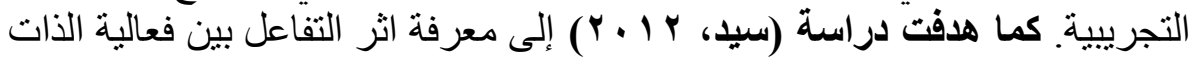

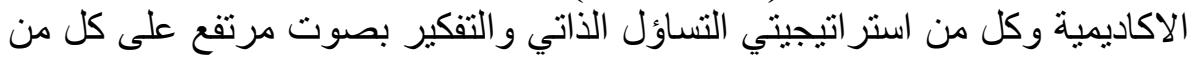

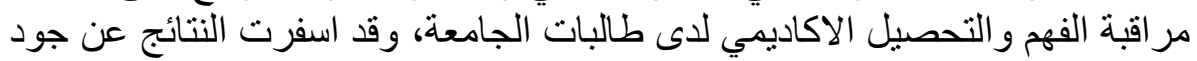

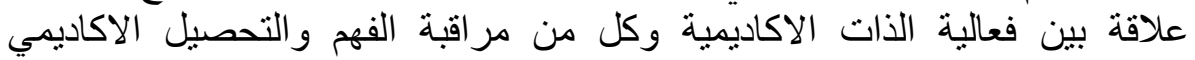

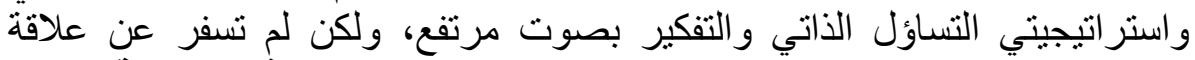

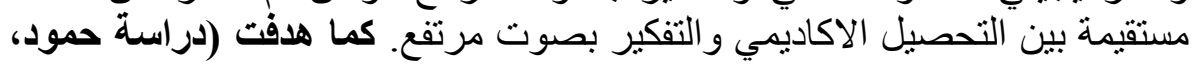

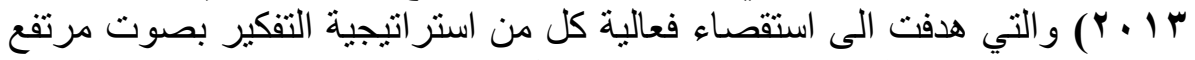

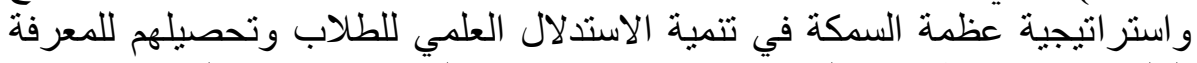

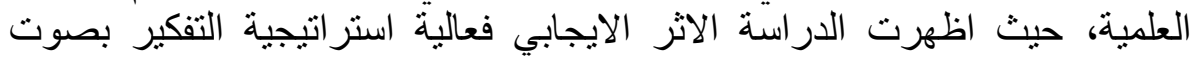

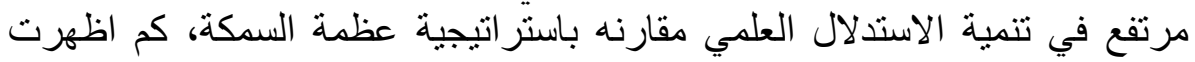
الدراسة عدم وجود فروق بين المجموعتين التجريبيتين بالنسبة لتنمية التحصية التحيل

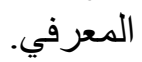

\section{من خلال العرض السابق يتضح ما يلي:}

ـ استخدام استر اتيجية التفكير بصوت مرتفع في مر احل تعليمية متنو عه.

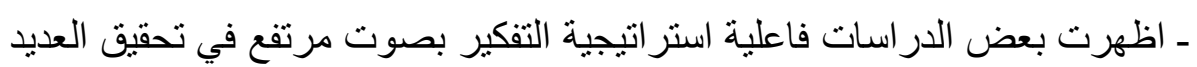

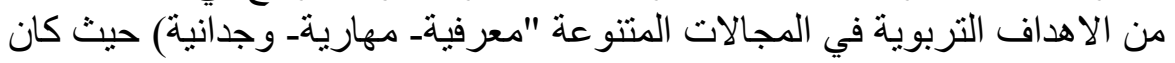

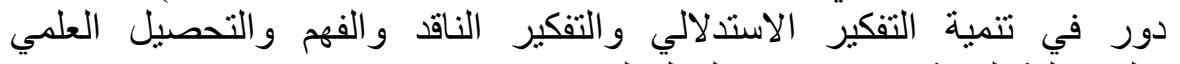
و المسئولية البيئية والاتجاه نحو العمل التعاوني.

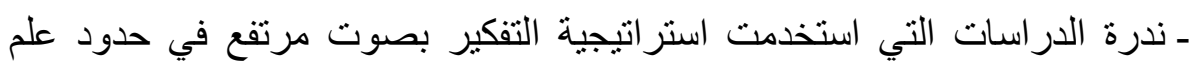
الباحثة.

\section{ثانيا: التفكير التأملي Reflective Thinking: بأنه}

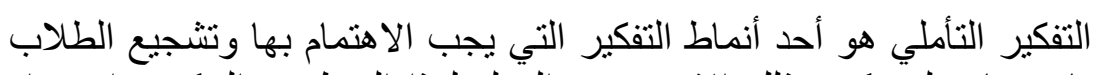

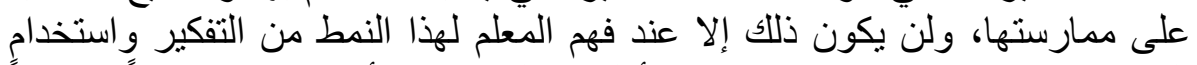

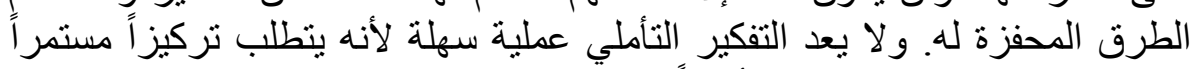

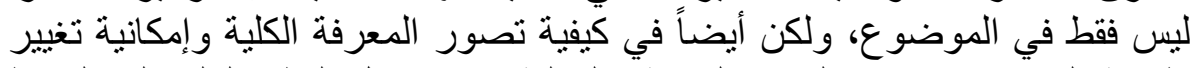

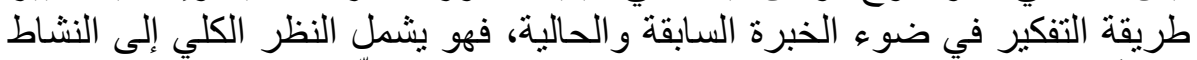

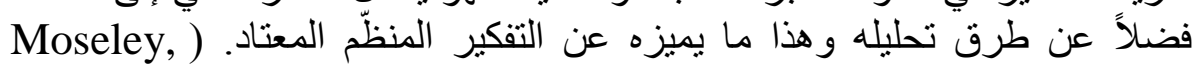
(2005, p314

كما أكد ليونز (Lyons, 2010, p12) على أن يكون التفكير التأملي هدفاً

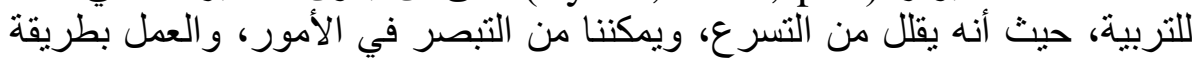
مدروسة ومتعددة لتحقيق أهداف محددة. وترى كوفاليك وأولسن (Kovalik \& Olsen, 2010, p4) بأن الميل إلى إنى التفكير التأملي عادة لا تقدر بثمن بالنسبة للعقل، فهو يقلل من الإجهاد، ويحسّن التعلم الميل 


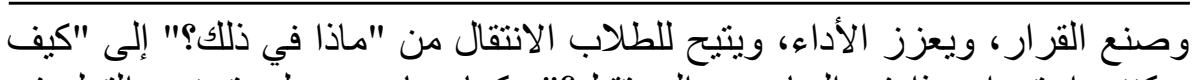

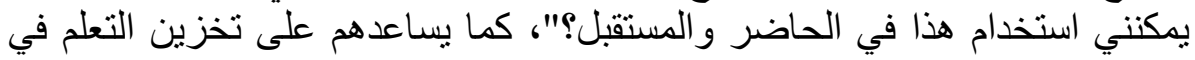
الذاكرة طويلة المدى. تعريف التفكير التأملي:

بدأ التفكير التأملي في بداية كتابات ديوي Dewey وغيره من التيري المربين كنوع

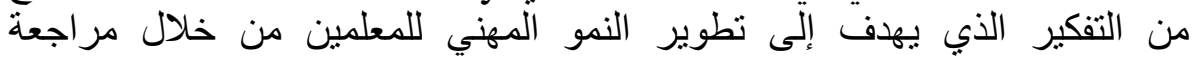

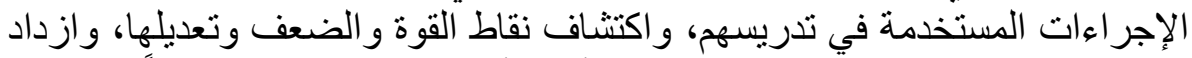

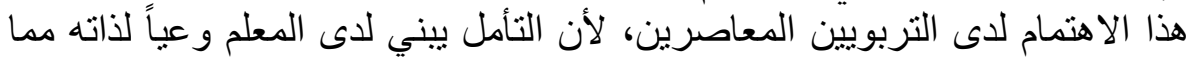

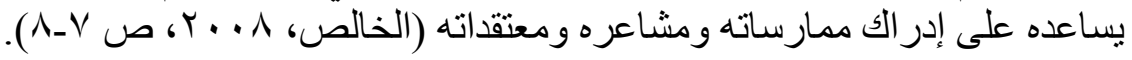

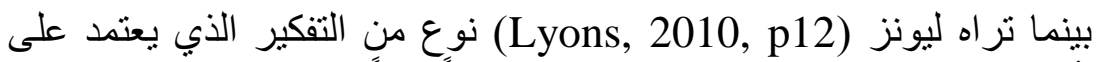

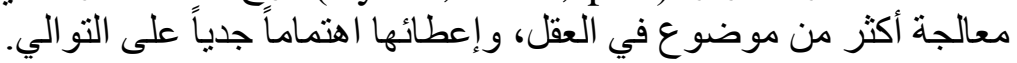

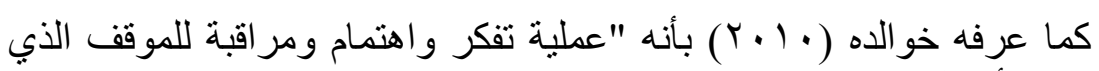

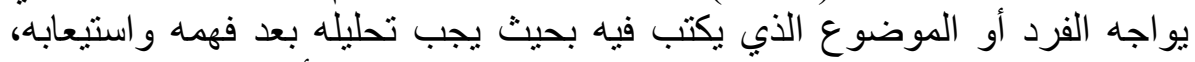

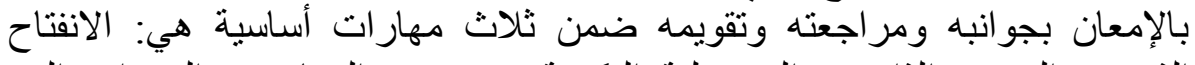

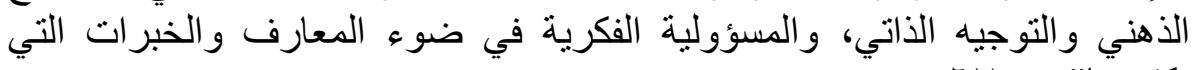
يكتسبها". صنآ

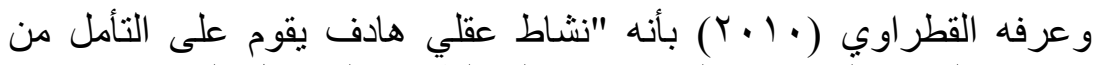

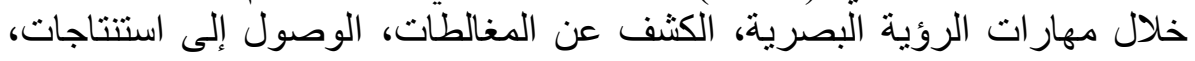

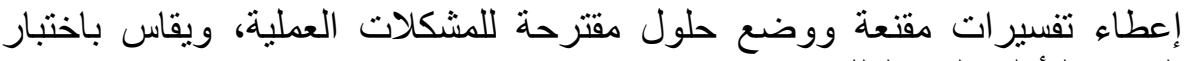

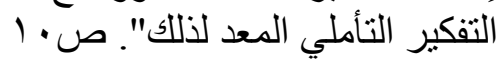
يتضح مما سبق أن التفكير التأملي:

- يتم تحفيزه عن طريق تعريض الفرد لمشكلة أو موقف يصعب على على الفرد التعامل معه فيلجأ للتأمل في أجز ائه. ـ أنه نوع من التفكير القائم على تحليل الموقف وفهم العلاقات الموجودة بين أجز اهه.

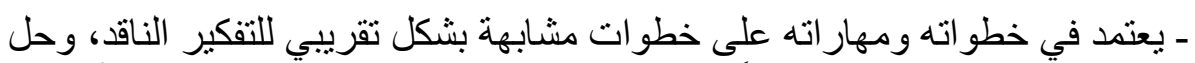

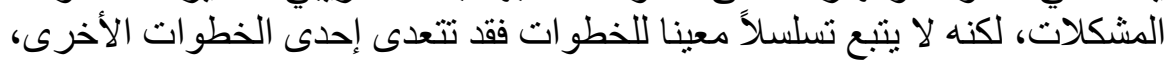
لكنه يركز كثير ا على نقد الافتر اضات لنات وتقويم النتائج. - يربط بين الخبرات و المعارف السابقة و الحالية للطالب.

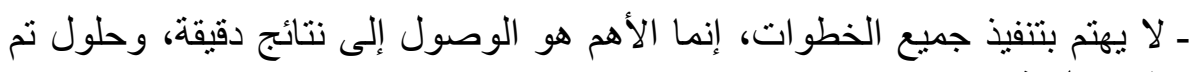
تقويمها بدقه.

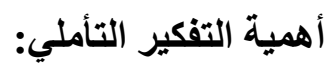
تتمثل أهمية التفكير التأملي في مساعدة الطلاب على ما يلي: 
( 9, Y. . 9, العارضة; Song, 2006, 75)

- ربط المعرفة الجديدة بفهم سابق.

- جعل المتعلم متفتح عقلياً وتنمي لديه الاحساس بالمسئولية. - يجعل المتعلم اكثر سيطرة على تفكيره، و استخدامه بنجاح. - ينمي الثعور بالثقة بالنفس في مو اجهة المهمات الدر اسية و الحياتية.

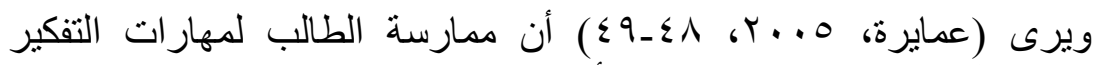

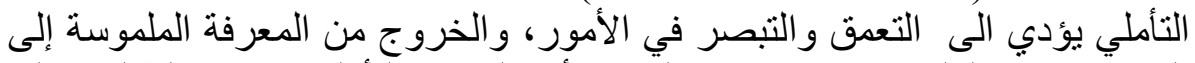

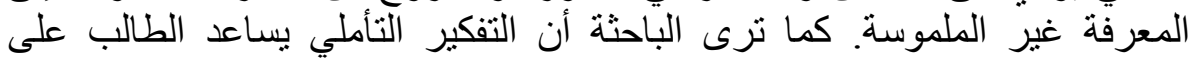

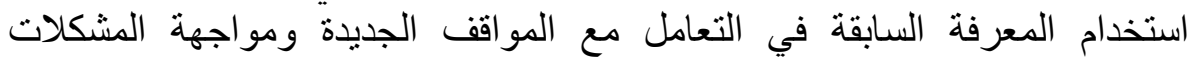
المختلف ووتحليلها والتخيط لها واصدار القرارات التهات المناسبة كما انه بيساعد على تحمل المسؤولية والسيطرة على التفكير و النجاح في اداء المهام.

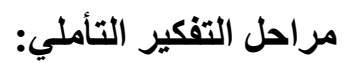

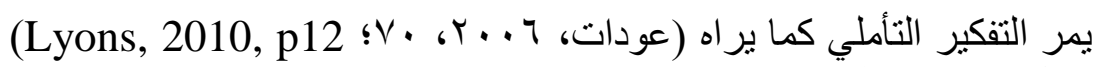
بعدة مر احل و هي كما يلي: ـ الوعي بالمشكلة وفهم المشكلة. - وضع الحلول المقترحة وتصنيف البيانات و اكتشاف العلاقات. ـ استنباط نتائج الحلول المقترحة .

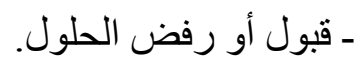

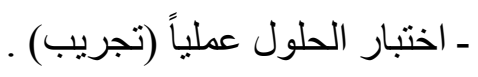
ـ ق قبول أو رفض النتيجة.

ولا تسير خطوات التفكير التأملي باستمرار بنفس التتابع، كما أنها ليست

بالضرورة مر احل فكرية منفصلة، ولكن يحدث كثير من التداخل فيما بينها.

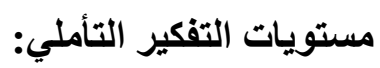

يعتبر التفكير التأملي أحد النشاطات العقلية التي يقوم بها الفرد في أغلب

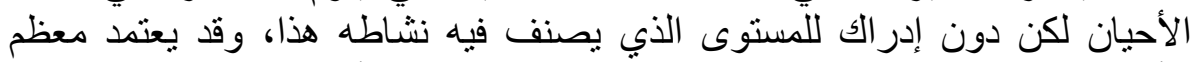

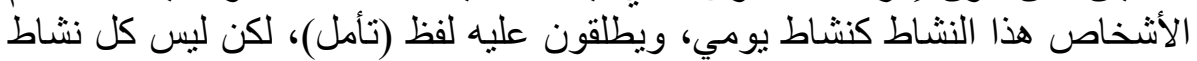

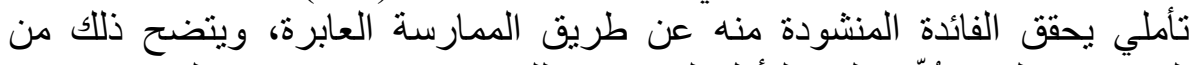

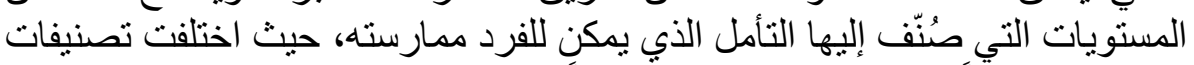

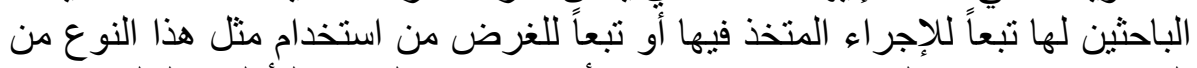

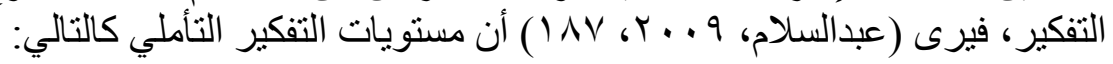


المستوى الأول: التأمل العابر اليومي:

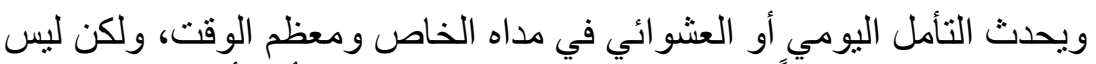

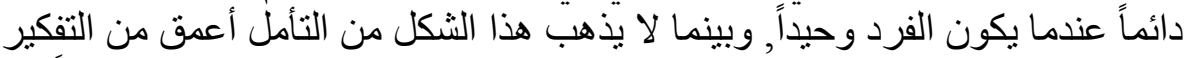

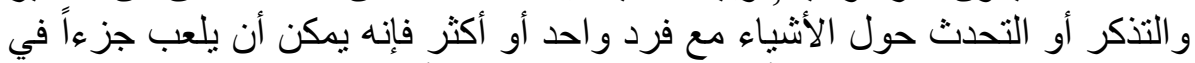
المستويات المتعدة الكثيرة للتأمل التي تبلغ ممارسة التئ التأمل. المستوى الثاني: التأمل المدروس:

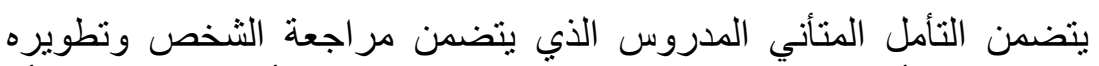

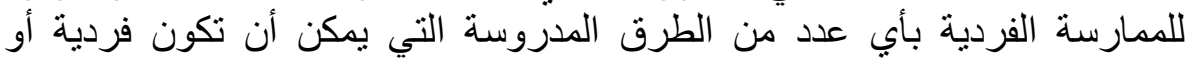

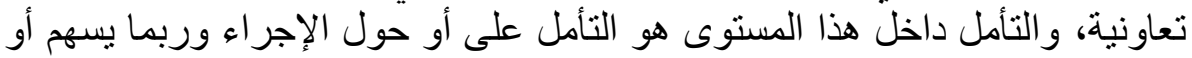

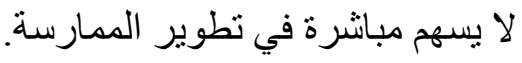

المستوى الثالث: التأمل المدروس والمنظوئي- المبرمج مeliberate and :systematic reflection - programmatic

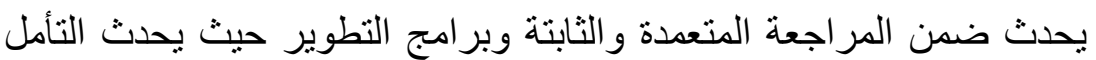

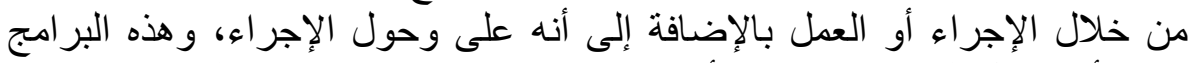

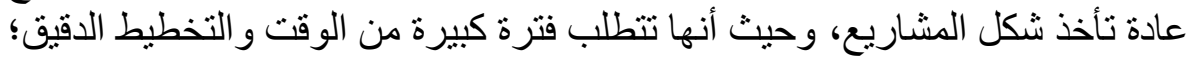

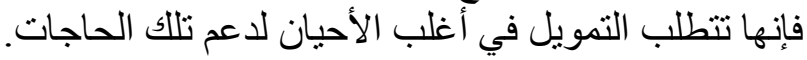

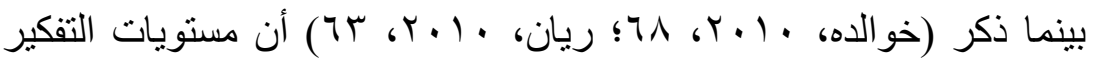

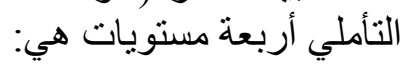

ا ـ العمل الاعتيادي (الروتين) (Habitual Action): و هو ذلك العمل المتكرر الذي يؤديه الفرد فيصبح نشاطاً يؤديه تلقائياً.

r ـ الفهم (الاستيعاب) (Understanding Reflection): ويطلق عليه اسم العمل التفكيري، إذ يفيد الطالب من المعرفة الموجودة من دون محاولة تقويم تللك المعرفة. r- التأمل (Reflection):

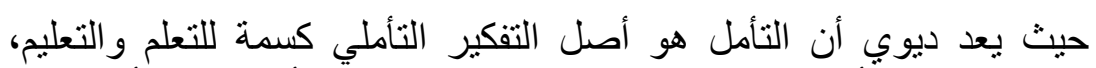

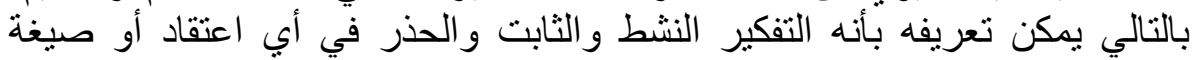
مفترضة من المعرفة في ضوء الأسس التي تدعمه، و النتيجة التي يذهب إلئ إليها.

ع ـ التأمل الناقد (العميق) (Critical Reflection):

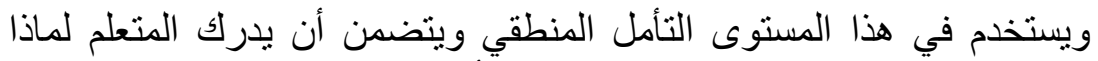

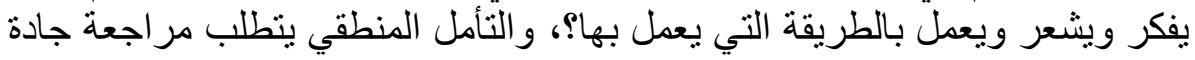
وو اقعية للافتر اضات السابقة من الّوعي و اللاو عي السابق للتعلم ونتائجه. 
وترى الباحثة بأنه مهما اختلفت مستويات التفكير التأملي، فإن الاستخدام غير التبل

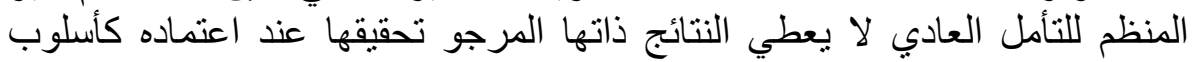

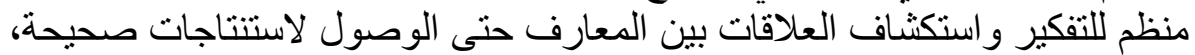

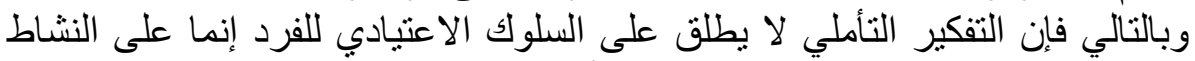

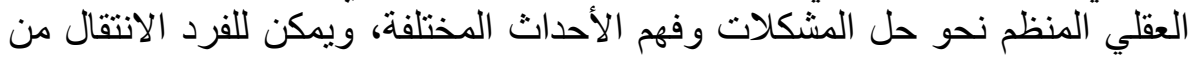

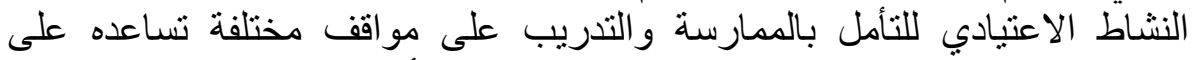

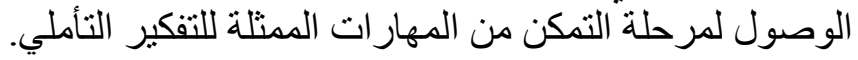

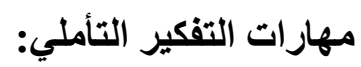

يشتمل التفكير التأملي على خمس مهارات أساسية وهي: (العماوي، 9 . . ؟؟،

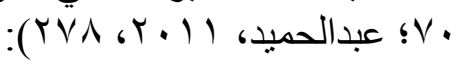
1 ـ التأمل و الملاحظة Meditation and observation:

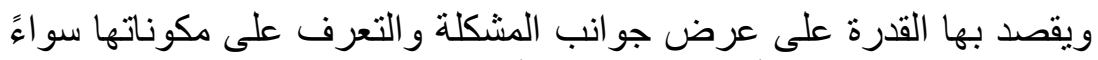

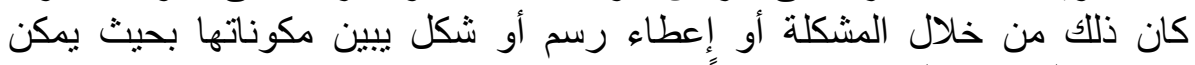
اكتثاف العلاقات الموجودة بصرياً. بـ الكثف عن المغالطات parallelisms revealing القدرة على تحديد الفجوات في المشكلة وذلك من خلال تحديد العلاقات غير إندان الصحيحة أو غير المنطقية أو تحديد بعض المض الخطوات الخاطئة في إنجاز المهام التربوية.

rـ الوصول إلى استتناجات Conclusions:

القدرة على التوصل إلى علاقة منطقية معينة من خلال رؤية مضدون المشكلة و التوصل إلى نتائج مناسبة.

ع - إعطاء تفسير ات مقنعة Provide Convincing explanations:

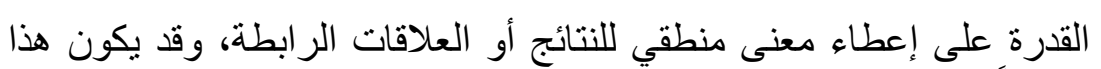

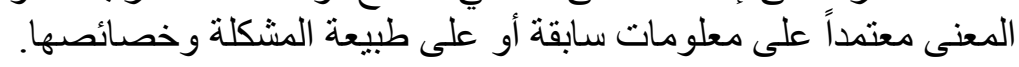
هـ وضع حلول مقترحة Proposed Solutions:

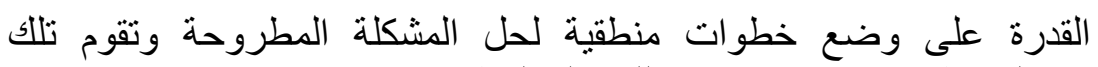
الخطوات على تطور ات ذهنية متوقعة للمشكلة المطروحة.

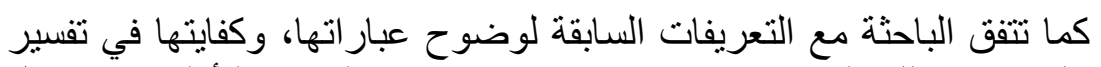

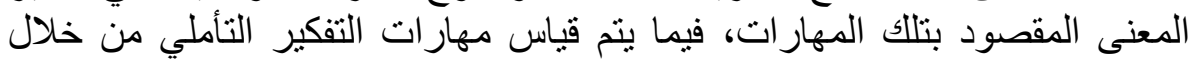
إجابات التلميذات على اختبار مُعد لقياسها. 
خصائص الشخص التأملي:

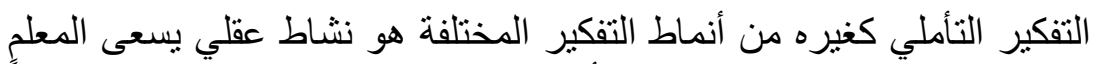

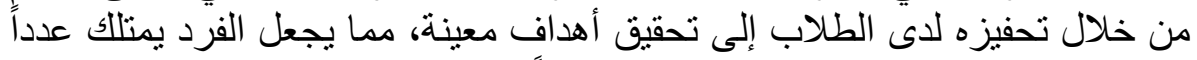

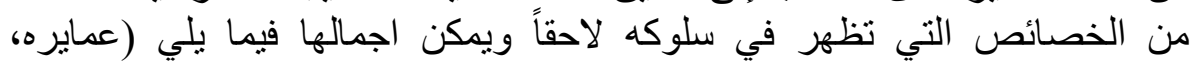

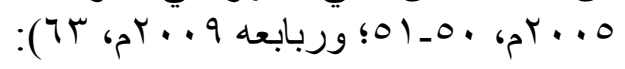

- ميقلل من الاندفاع أو التهور.

ـ الاستماع للآخرين مع فهمهم وتقمصهم العاطفي.

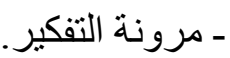

ـ تصوير المعرفة السابقة وتطبيقها في مواقف جديدة

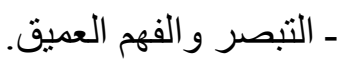
ـ التساؤل وحب الاستطلاع. ـ الاستمتاع بحل المشكلات عن طريق إثارة الأحاسيس مثل الظن و الاعنتقاد.

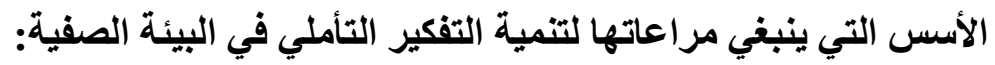

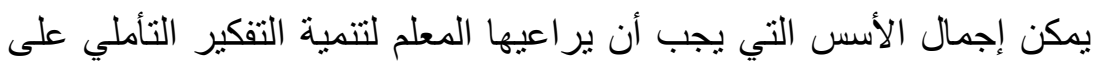

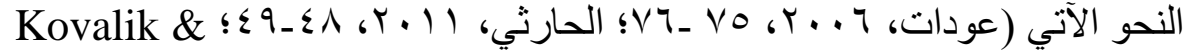
:(Gurol, 2011 , 393 ؛Olsen, 2010, 4

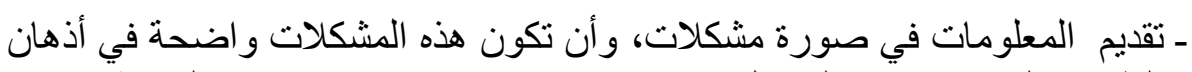
الطلاب؛ لكي يتعودو ا على حل ما يعترضهم من مشكلات في حياتهم اليومية. ـ إنر الك الطلاب في التفكير، ووضع الخطط للمواقف و المشكلات التي تو اجهمه في حياتهم الدراسية.

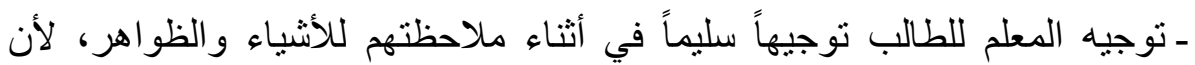

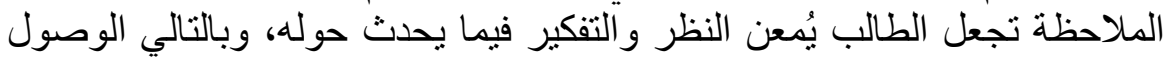

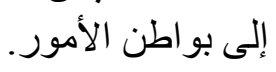

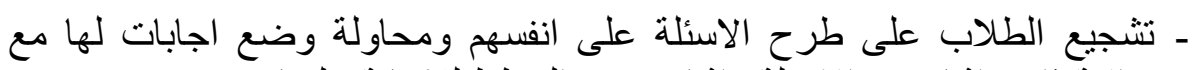
مر اقبة ذاتهم اثناء رح الاسئلة و اثثاء وضع الانئلة على الخطط للإجابة عليها.

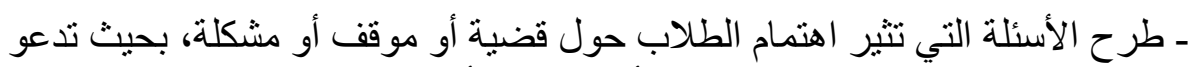

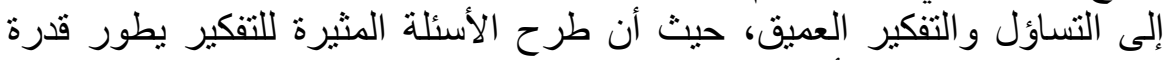

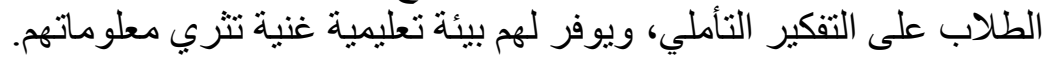

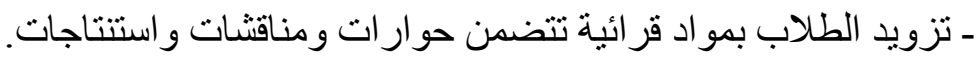

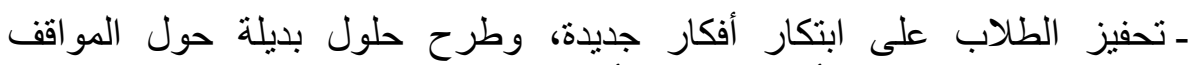
المطروحة، ومن ثم مكافأته على تلكار الأفكار و الحلول. تلون 


$$
\text { ـ تقديم الأسئلة التي تتطلب أكثر من إجابة، أو رأي، أو فكرة. }
$$

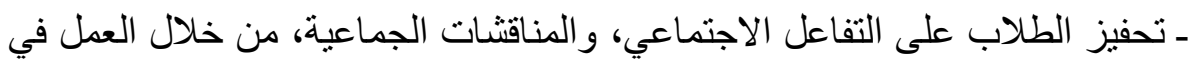
مجمو عات تعاونية.

ـ استخدام الاستر اتيجيات التدريسية والبيئية الصفية التي تساهم في تنمية مهار ات

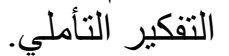

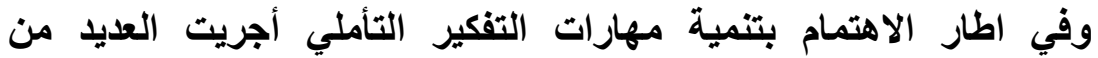

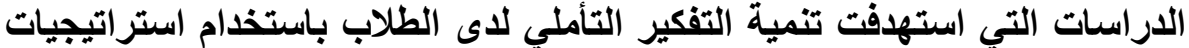

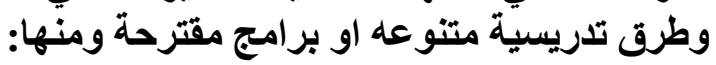

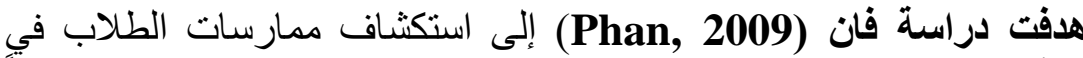

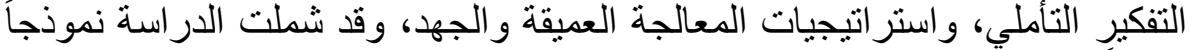

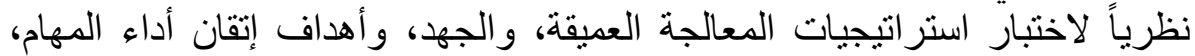

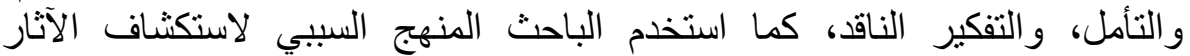
المباثرة لهذه التوجهات النظرية على تحقيق الطلاب للأهداف الأكاديمية والتعلمية. كما شملت الدراسة عينة من الطلاب الجامعيين الذين أكملوا السنة الثابنة الثانية والثالثة

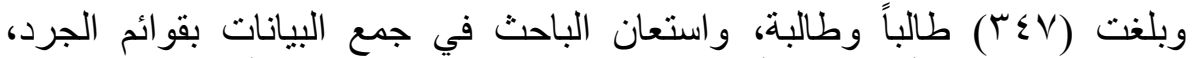

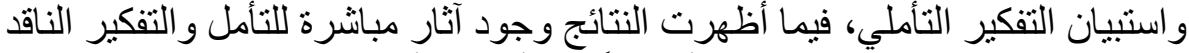

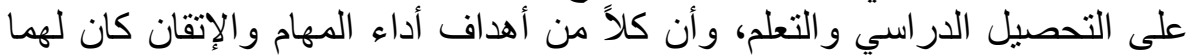

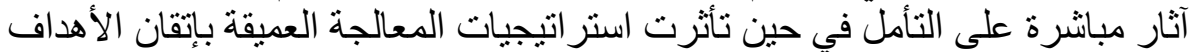

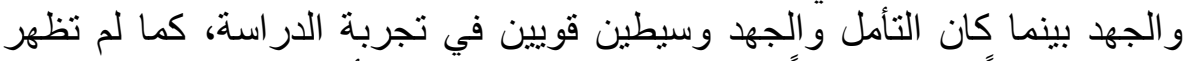

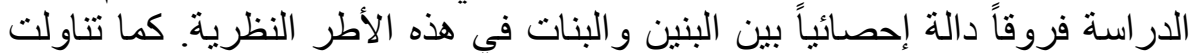

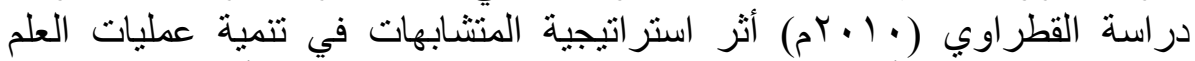

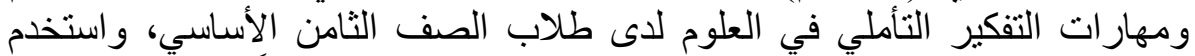

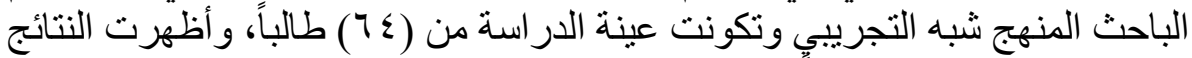

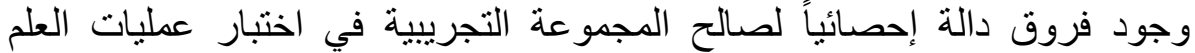

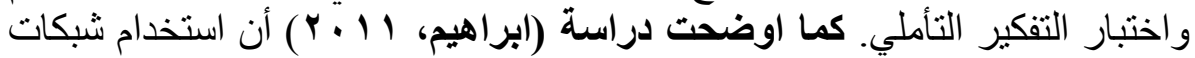

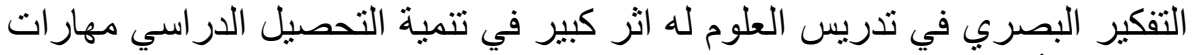

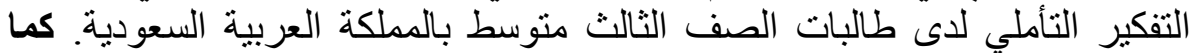

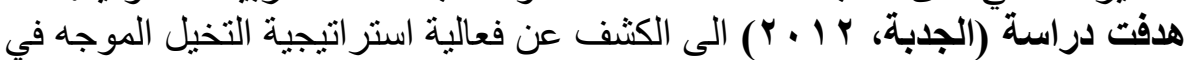

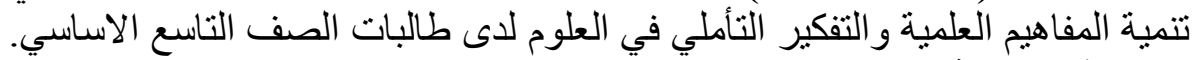

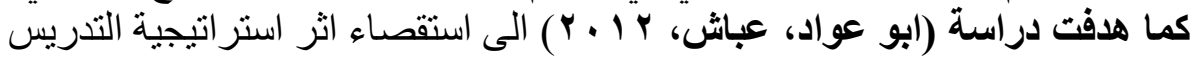

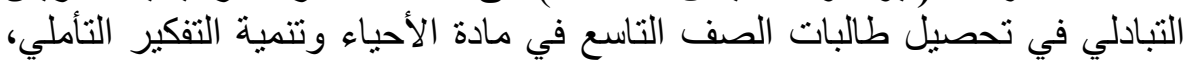

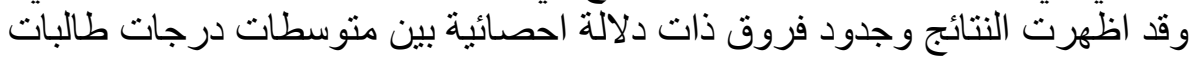

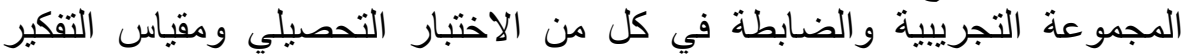

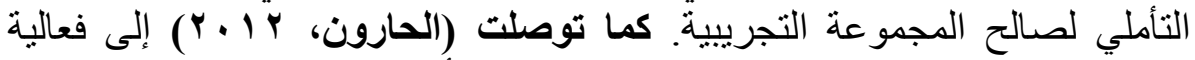

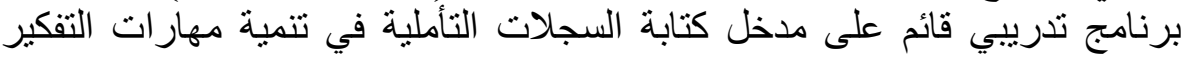




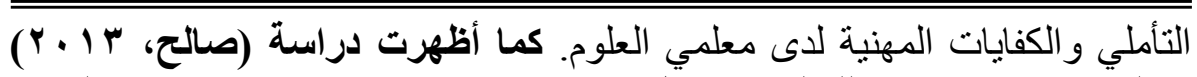

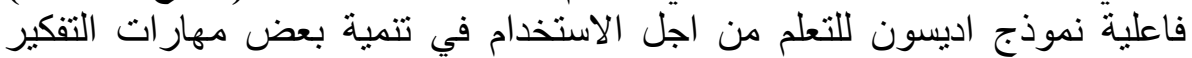

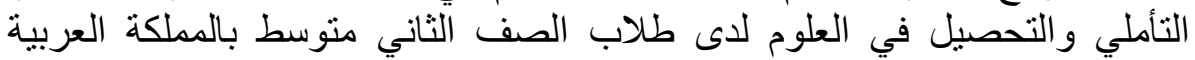

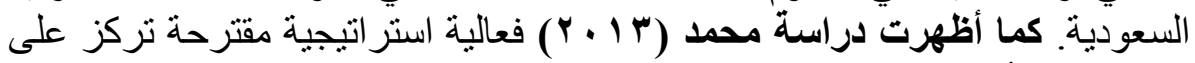

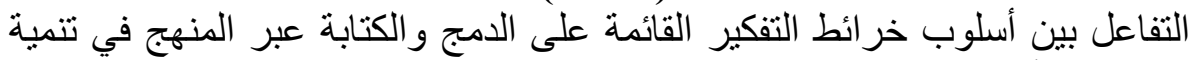

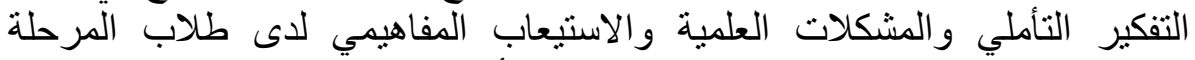

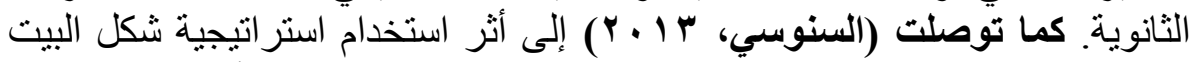

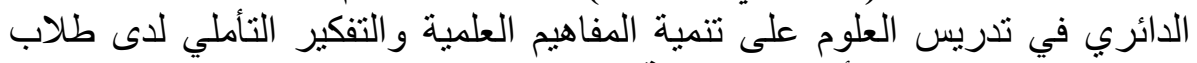

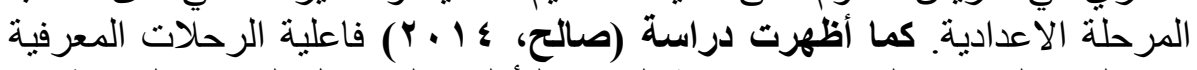

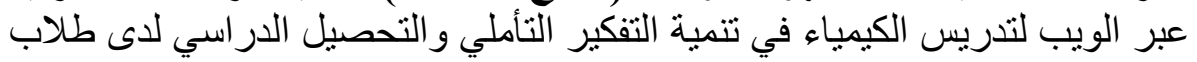
المرحلة الثنانوية.

\section{التعليق على الاراسات السابقة:}

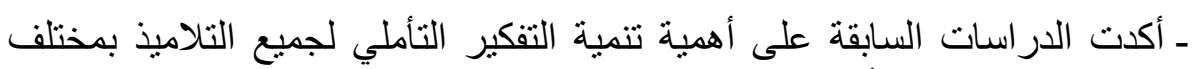

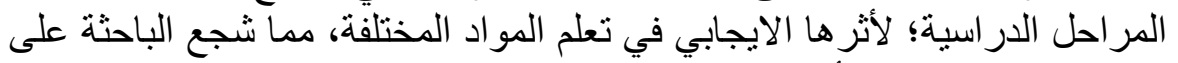
تناول هذا المتغير ذو الأهمية.

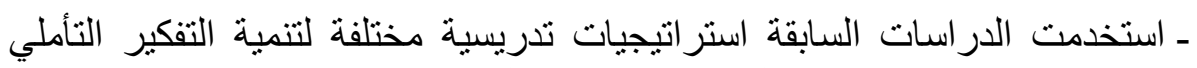

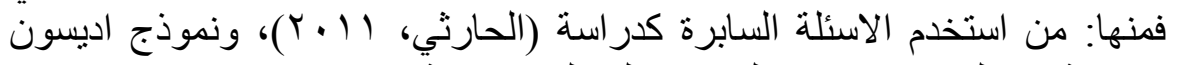

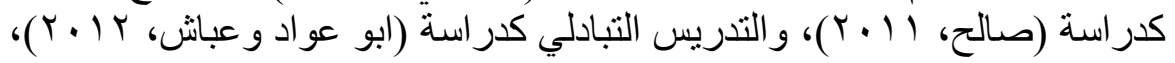

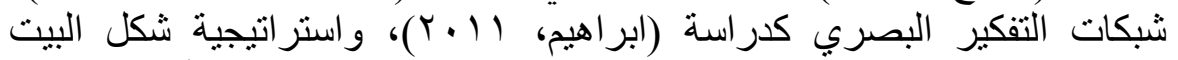

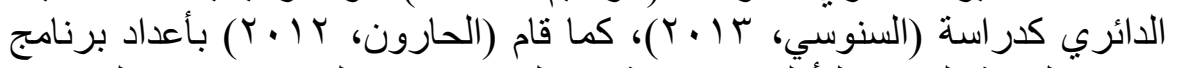

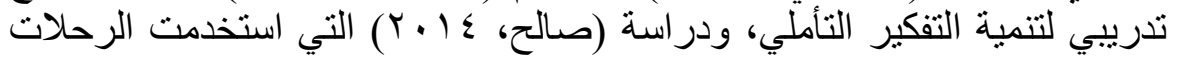
المعرفية.

ـ لا توجد دراسة سابقة- في حدود علم الباحثة تناولت معرفة فاعلية استراتيجية

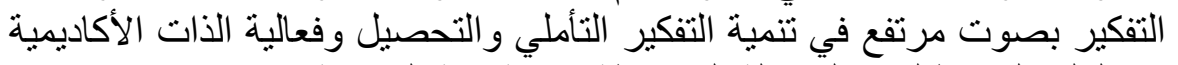

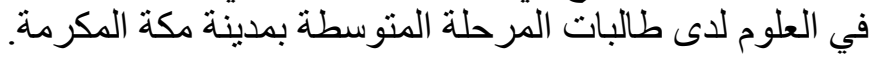

ثالثاً: فعالية الذات الأكاديمية في العلوم:

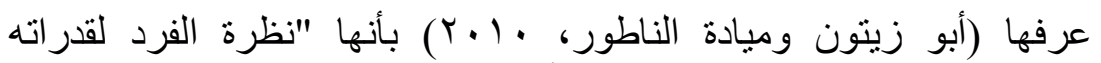

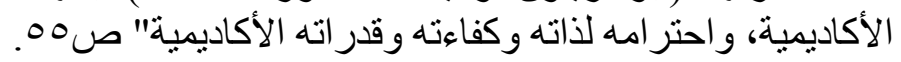

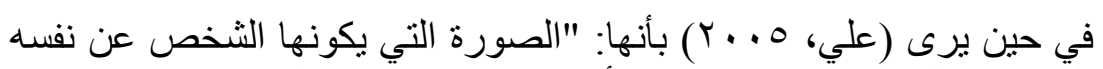

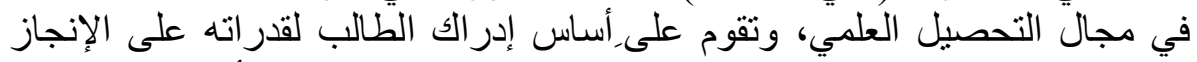

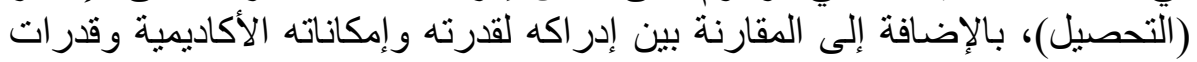

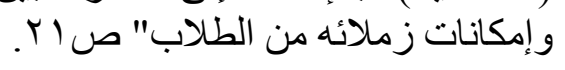

ويستند مفهوم فعالية الذات إلى نظرية باندورا Bandura للتعلم المعرفي

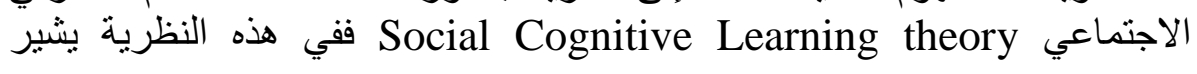




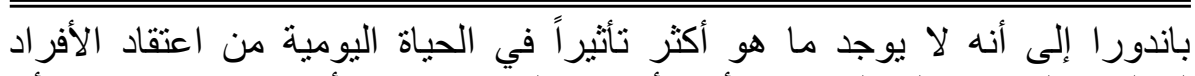

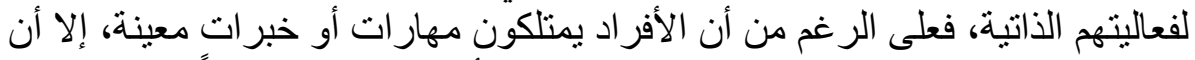

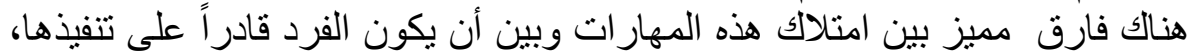

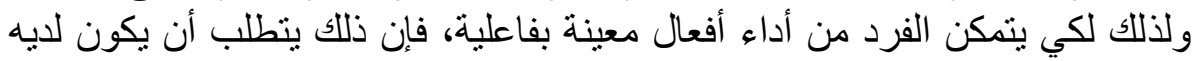

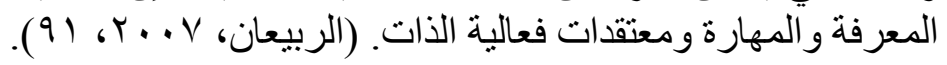

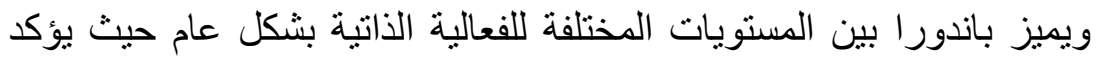

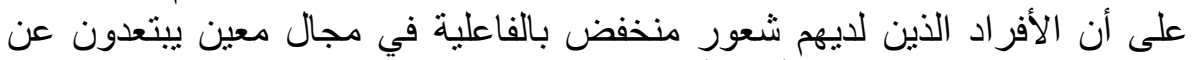

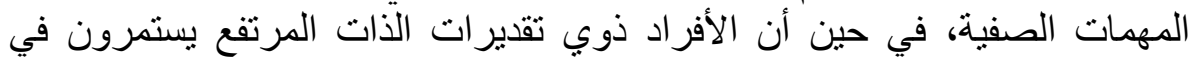
المهام الصعبة (Araujoa \& Lagos, 2013).

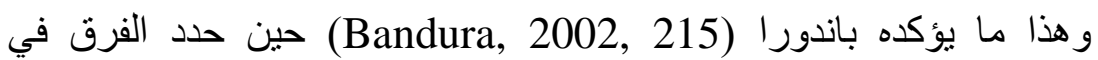

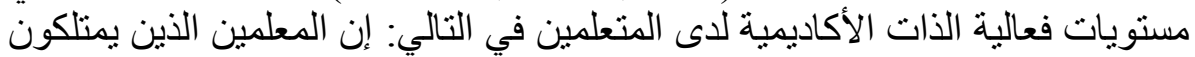

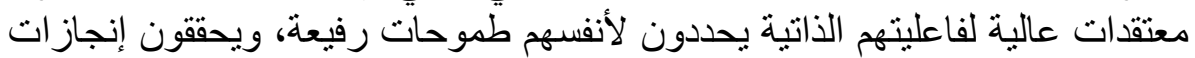

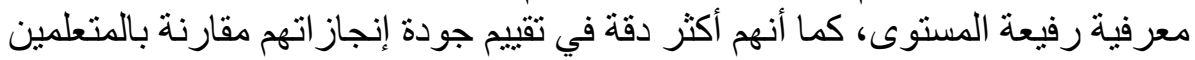

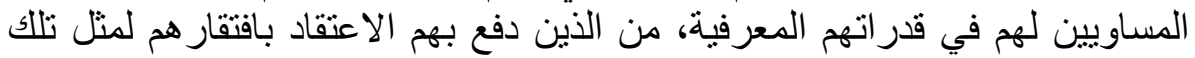
القدر ات. - ات.

\section{مما سبق يظهر أن الذات الاكاديمية:}

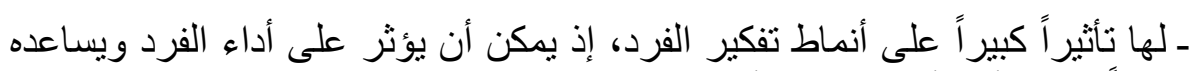
ذاتباً على الأداء أو يعيقه عن أدائه.

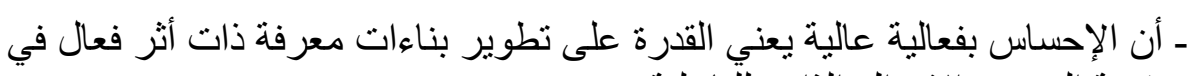
تقوية الوعي و الإدر الك الذاتي للفاعلية.

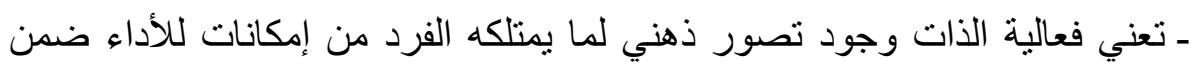
ظروف اجنماعية فهو لذلك دافع معرفي اجتماعي.

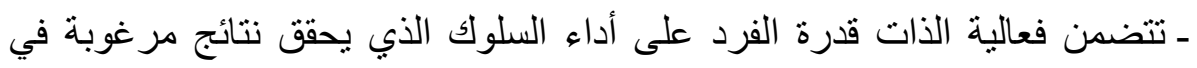
موقع معين.

\section{أبعاد فعالية الذات الأكاديمية: معان:}

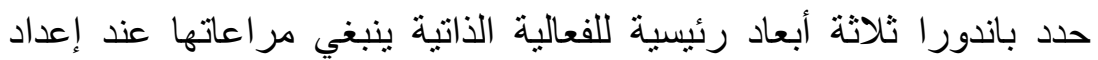

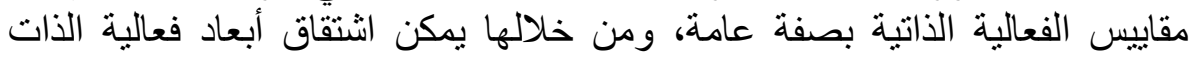

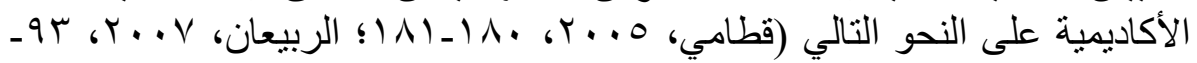

\section{ا ـ درجة الفاعلية}

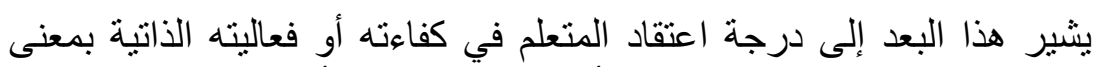

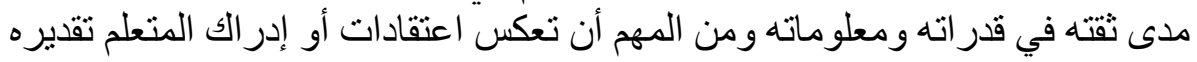


لذاته وبأن لايه درجة من الفعالية الذاتية تمكنه من أداء ما يوكل إليه أو يكلف به دائماً ولس أحياناً.

r ـ عمومية الفعالية: Generality Efficacy

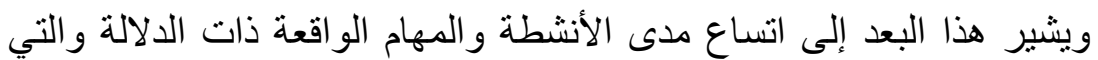

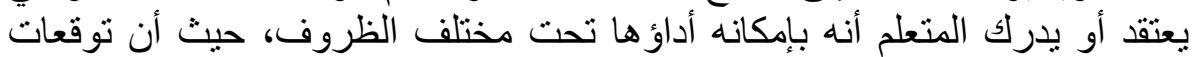
الفعالية تنتقل إلى مو اقف مشابهة للمو اقف الأولية التهانة rـ قوة الفعالية: strength efficacy

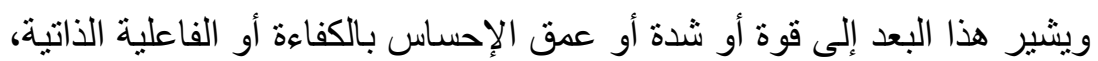

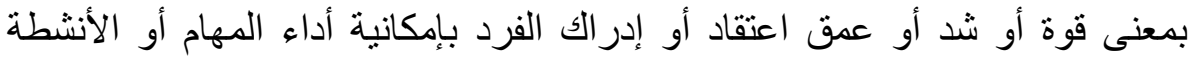
موضع القياس.

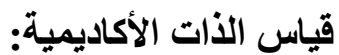

تقاس فاعلية الذات الأكاديمية عن طريق تقديم فقرات لفظية في قائمة، أو لقابئ مقياس يستجيب فيه المفحوص عن طريق التقرير الأبرئ الذاتي.

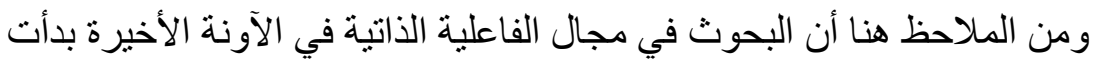

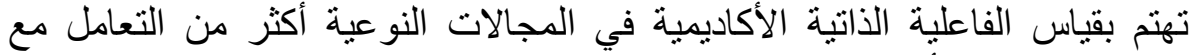

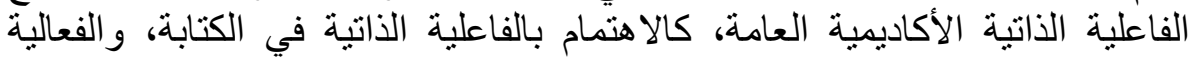

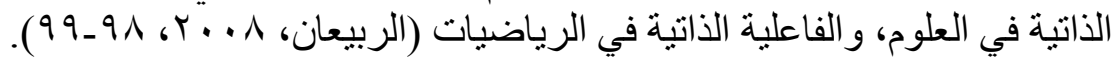

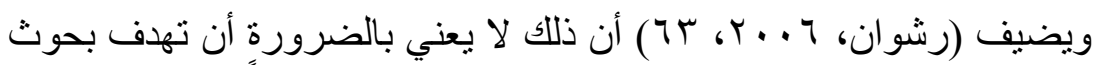

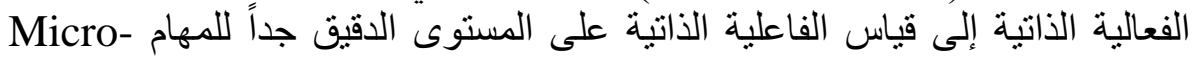

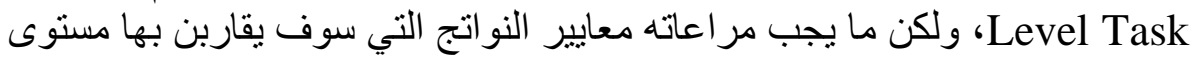

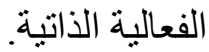

مصادر فعالية الذات الأكاديمية:

يمكن تحديد المصادر التي يمكن أن تسهم في تفسير معتقدات الأبهات الفعالية الذاتية

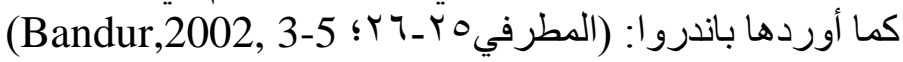

ا ـ إتقان الخبرات (Mastery Experiences):

تمثل الخبرات النشطة الهدفة أكثر مصادر المعلومات المتات المتعلقة بالفعالية الذاتية

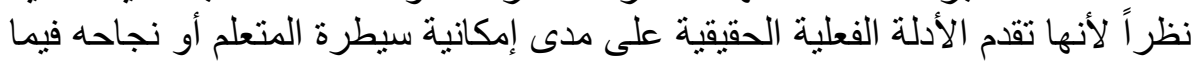
يسعى لتحقيقه. r- الخبرات البديلة (Vicarious Experiences):

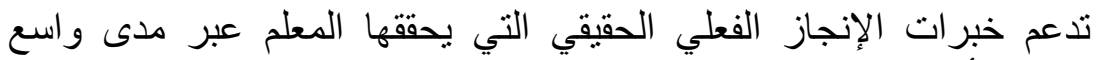
ومتنوع من الأنشطة والمهام الثعور والاعتئقاد الموجب بارتفاع مستوى الفعالية 
الذاتية وثباتها النسبي، ومقاومتها لأي تأثنير ات سالبة عليها كالفشل المؤقت في بعض عنر المهام.

بـ الاقناع الاجتماعي (Social Persuasion):

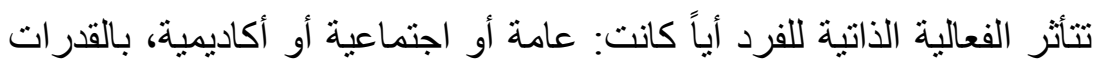

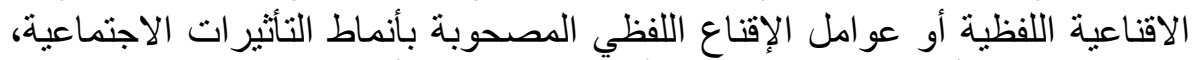

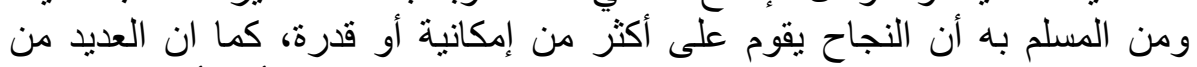

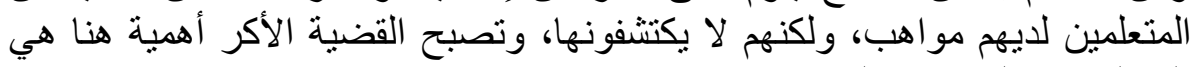
المو الفة بين القدر ات و المهام.

ع ـ الحالة النفسية الانفعالية:

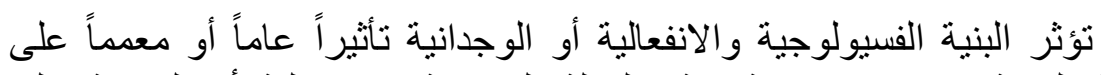

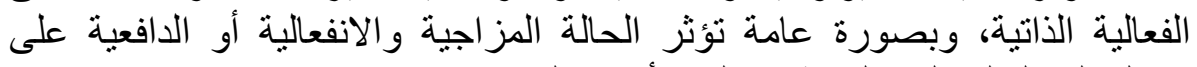
إدر الك المتعلم لفاعليته الذاتية، و على الأحكام التي يصدر هاء التها.

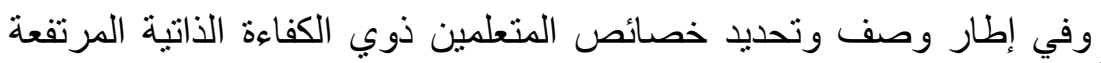

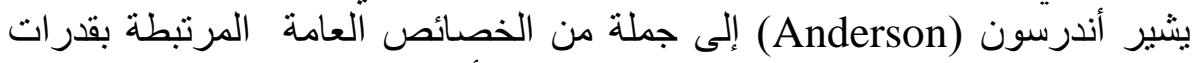

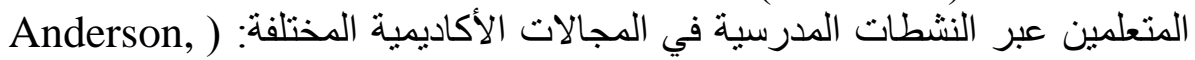
(2004, 20-21

ـ القدرة على التركيز على الهدف أو الغاية، والتوقع الإيجابي له.

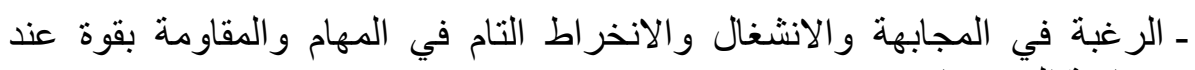
مجابهة الصعوبات.

ـ التفاني في إطار العمل كفريق نحو تحقيق الأهداف و الغايات. ـ التحكم الذاتي و القناعة الذاتية وتفهم الاحتمالات.

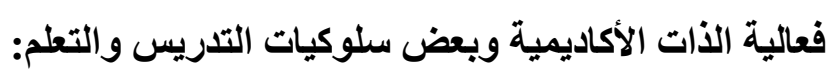

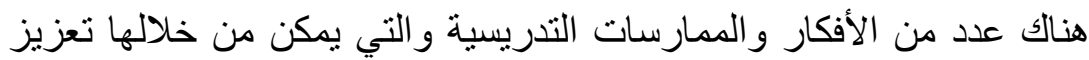

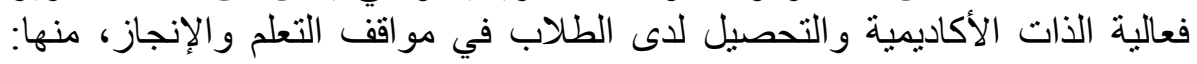

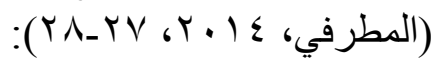

ـ تعمل الأهداف و الغايات المحددة للأداء على رفع الفعالية الفية الذاتية. ـ نوفير الحد الأدنى من المعرفة و المهار ات الإدر اكية الضرورية للتعلم.

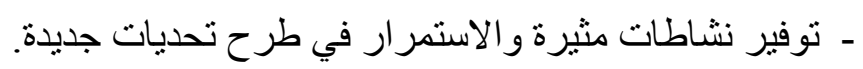
ـ تكون الأهداف الصعبة أكثر فاعلية مع تطور مهار ات المتعلمين. ـ تفعيل استخدام المجمو عات التعاونية، وبخاصة المجمو عات الصغيرة فئهور منها. ـ توفير فرص أمام المتعلمين يلاحظون فيها الأقران ويقدمون نماذج وحلو لاً صحيحة. 
ـ إنعار الطلبة بأية درجة نجاح يحرزوها في مواقف التعلم.

ـ تزويد المتعلم بالتقييم المناسب و التعليق على مستوى التهاح الأداء. ـ تطوير مهارة التفكير بصوت مسموع ( عال) و التحدث للألتات. ـ توفير قدر من المساعدات الأكاديمية الهادفة للمتعلمين.

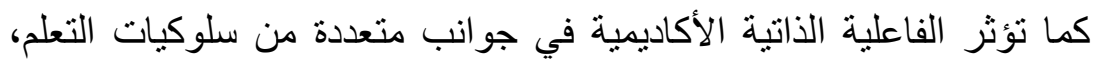

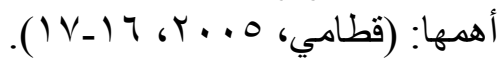
1 ـ اختيار الأنشطة (Choice of Activities):

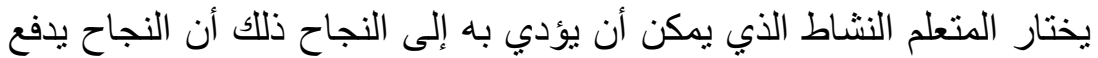

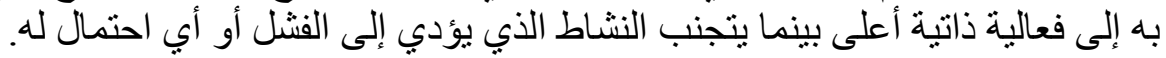
بـ المتابرة و الجهد (persistence and effect)

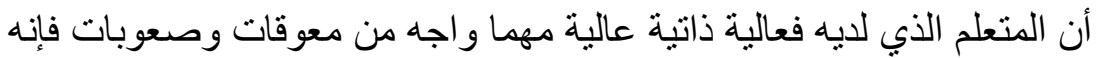

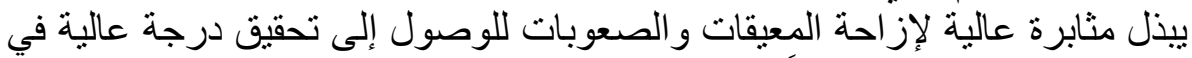
موضو ع در اسي يعتبر صعباً. rـ التعلم والانجاز : (Learing and Achievement) أن المتعلم الذي يطور فعالية ذاتية عالية ويدركها فإن ذلانك سيساعده على الإنى

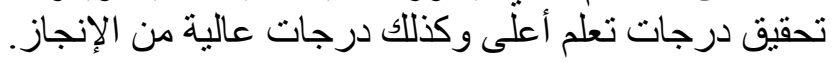

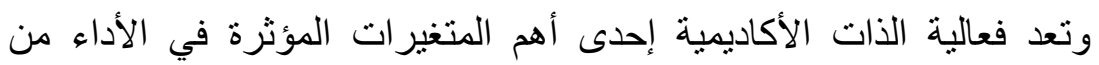

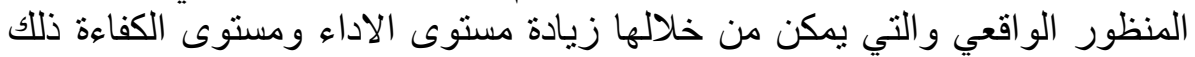

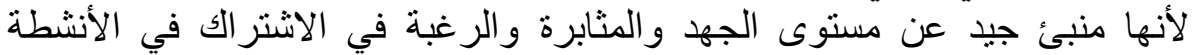
الصفية واختيار الأنشطة واختيار وتطبيق استر اتيجيات التجهيز والرية المعالجة بفاعلية

.(schunk 1991:215)

\section{ومن الدراسات التي تناولت فاعلية الذات الأكاديمي في العلوم:}

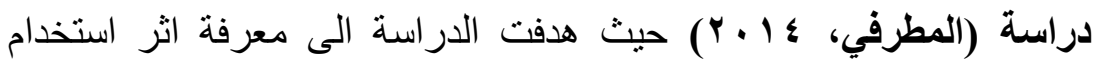

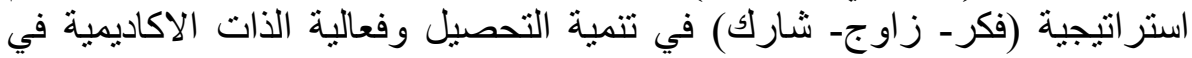

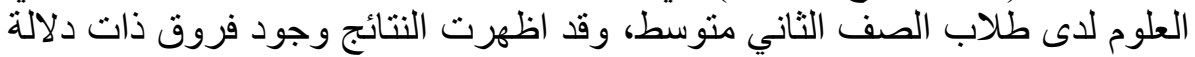

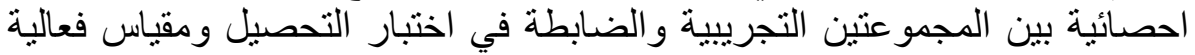

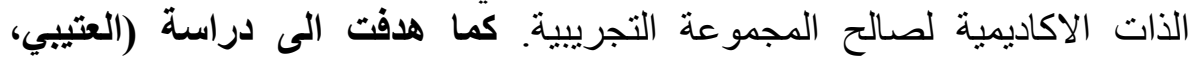

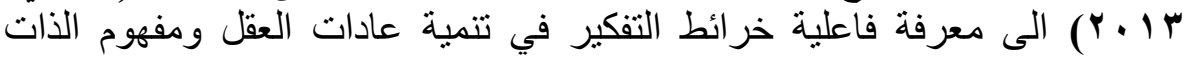

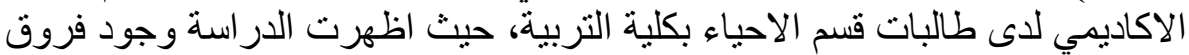

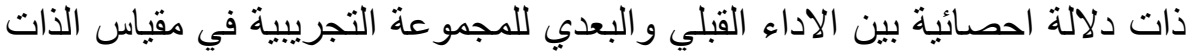

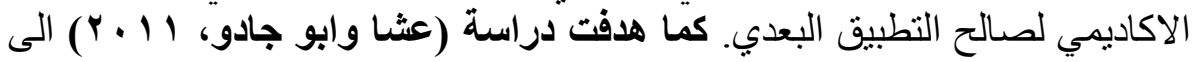
معرفة اثر استخدام استر اتيجيات التعلم النشط في تحسين التحصيل التحلئ العلمي ومفهوم 


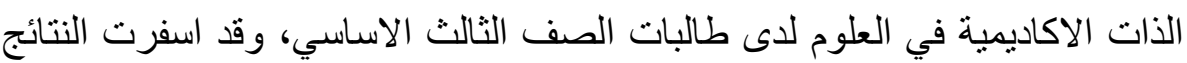

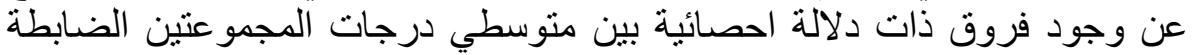

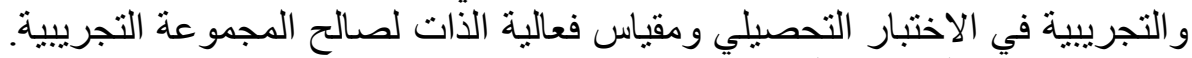

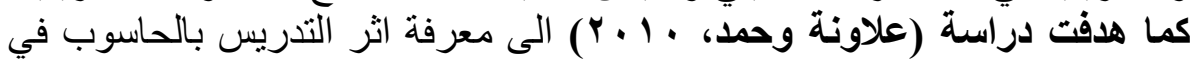

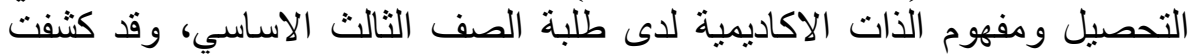

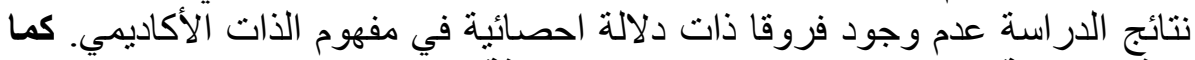

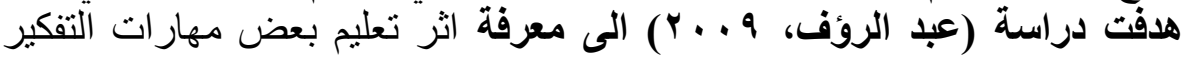

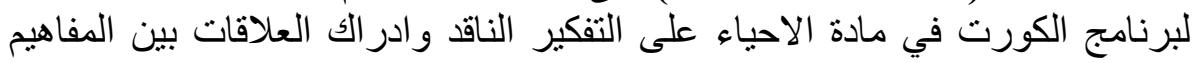

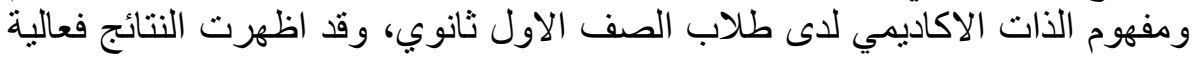

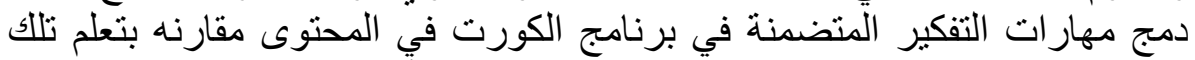

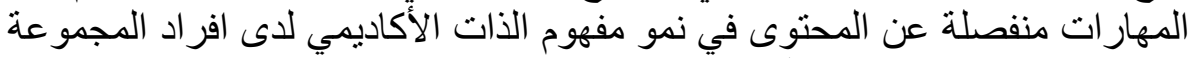

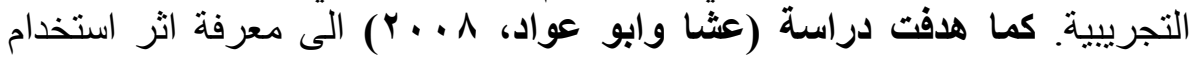

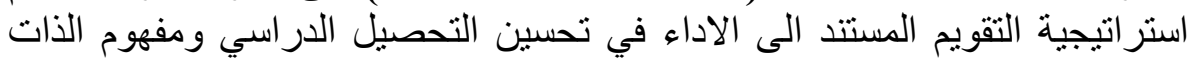

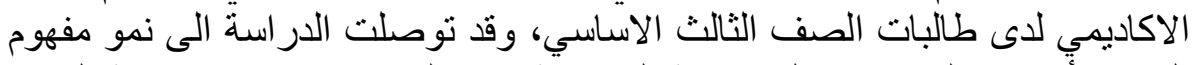

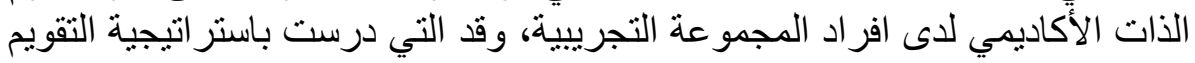

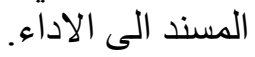

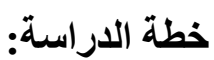

للتأكد من صحة فروض الدر اسة أُتبعت الخطو ات التالية:

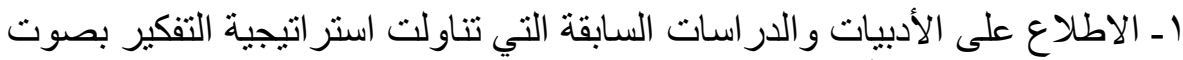

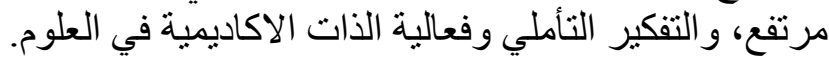

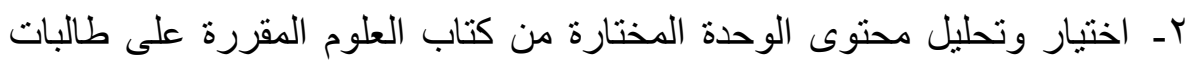
الصف الأول متوسط.

r- إعداد كل من (دليل المعلمة وأور اق نشاط الطالب) لتدريس الوحدة المختارة وفقا لاستر اتيجية التفكير بصوت التول مرتفع. ـ ـ عرض دليل المعلمة واور اق نشاط الطالب على مجمو عة من المحكمين. 0ـ إعداد أدوات الدر اسة و التأكد من صدقها وثباتها، وتشمل: - م اختبار التفكير التأملي "إعداد الباحثة". - - اختبار تحصيلي "إعداد الباحثة".

- مقياس فاعلية الذات الأكاديمية في العلوم "إعداد الباحتة".

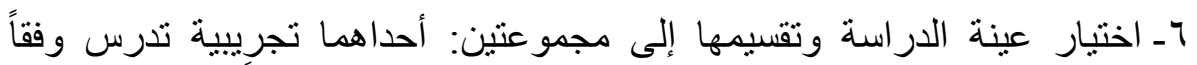
لاستر اتيجية التفكير بصوت مرتفع وارئ والأخرى ضابطة تدرس وفئاً للطريقة المعتادة في المدارس. 
V- إجر اء التطبيق القبلي لأدوات الدر اسة على عينة البحث.

Aـ تدريس الوحدة المختارة للمجموعتين: التجريبية باستخدام استراتيجية التفكير بصوت مرتفع و الضابطة بالطريقة المعتادة.

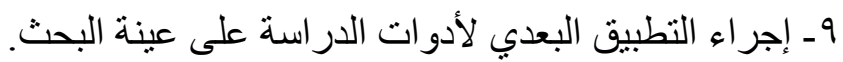

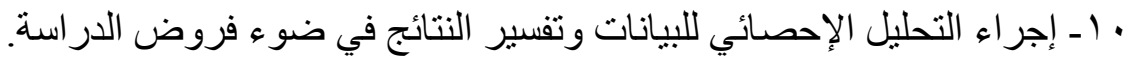
11 ـ ـ تقديم التوصيات و المقترحات في ضوء أنتائج الدر اسة.

منهجية الدراسة واجراء|تها:

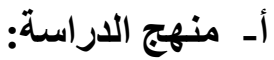

تعتمد الدراسة الحالية على المنهج التجريبي القائم على تصميم المعالجات التجريبية القبلية و البعدية من خلال المجمو عتين التاليتين:

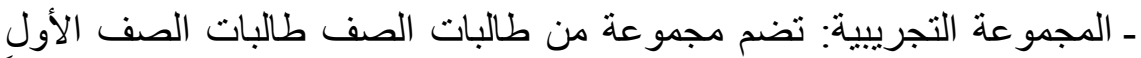
منوسط ,اللاتي الوحدة الثانية لمقرر العلوم المطور للصف التئ الأول المتوسط وفقاً

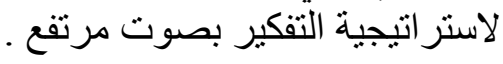

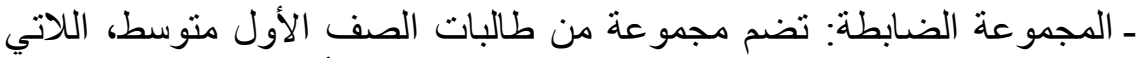
درسن الوحدة الثانية لمقرر العلوم المطور للصف الأول التهالت المتوسط بالطريقة

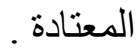
و الثكل (1) يوضح التصميم التجريبي للبحث الحالي:

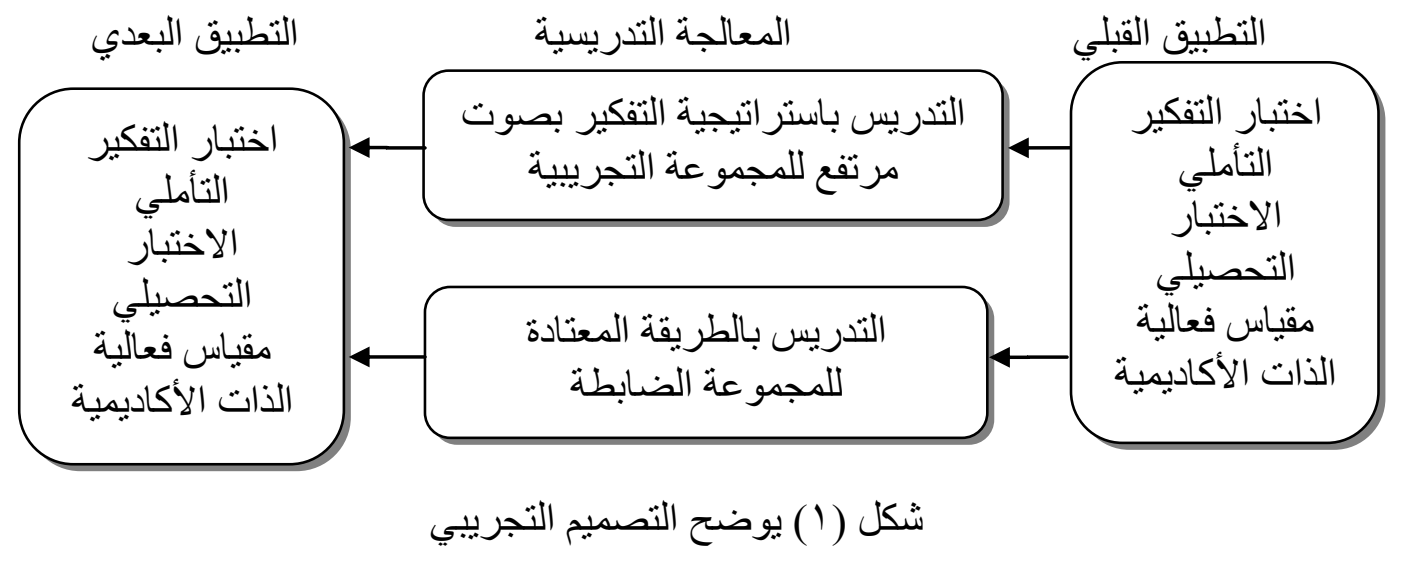

ب- مجتمع الدراسة وعينته:

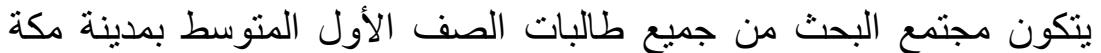

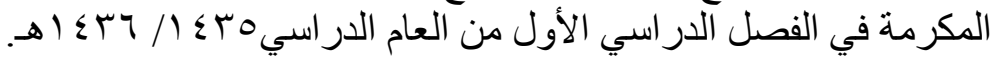




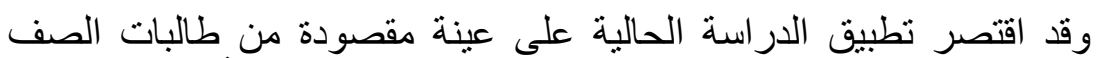

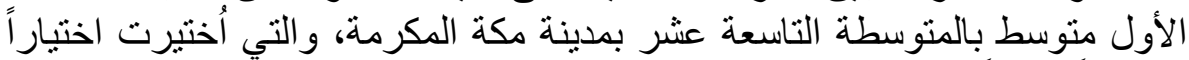

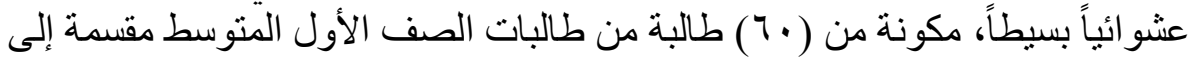

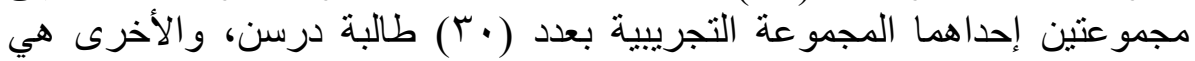

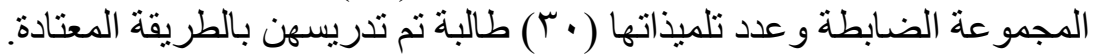

$$
\text { ج- متغيرات الدراسة: }
$$

ـ المتغير المستقل: هو طريقة التدريس، حيث درست المبت المجموعة التجريبية

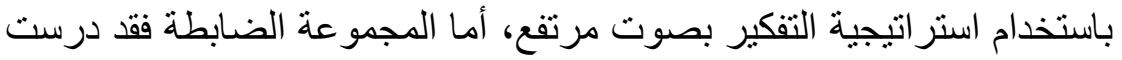
بالطريقة المعتادة في المدارس.

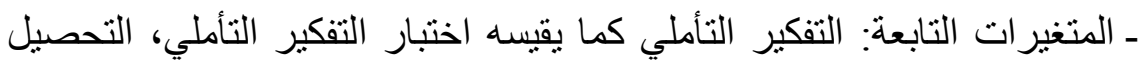

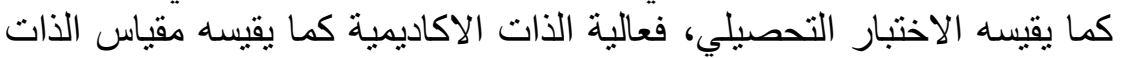

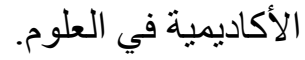

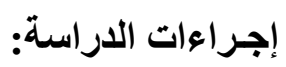
لاختبار صحة فروض البحث تم إتباع الإجر اءات التالية:

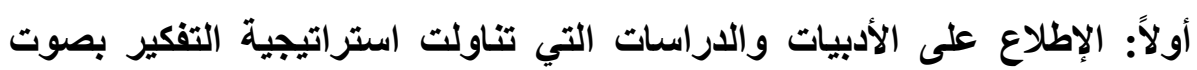

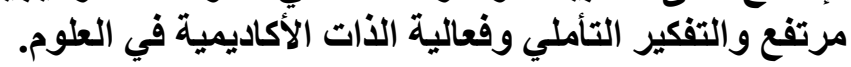
ثانياً: اختيار الوحدة الدراسية:

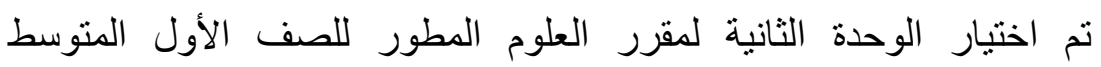

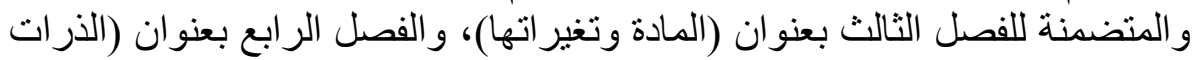
و العناصر والجدول الدوري).

\section{وقد وقع اختيار الباحثة على هذه الوحدة لعدة أسباب منها:}

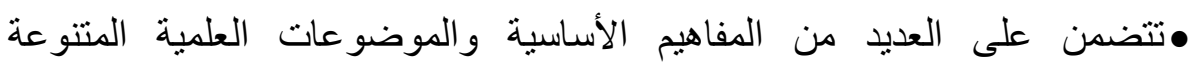
و المرتبطة بحياتنا اليومية.

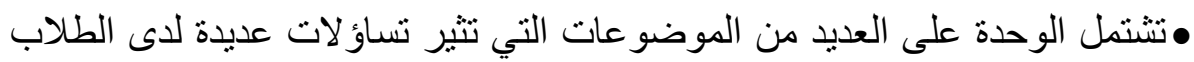

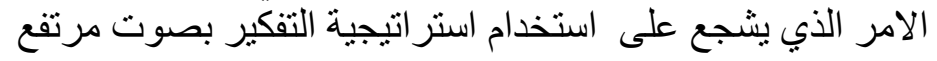

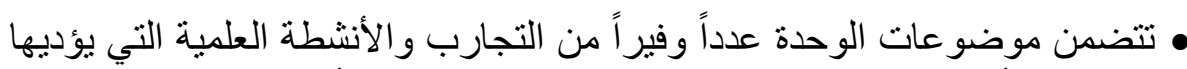

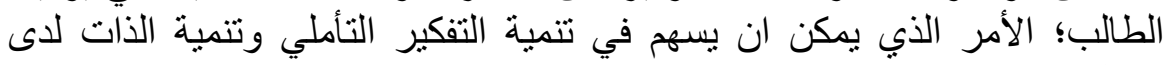

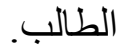

ثالثاً: تحليل محتوى الوحدة:

تم تحليل محتوى الوحدة بهدف حصر ما تضدمنته من وحدات مدات البناء المعرفي

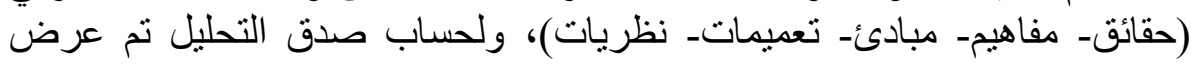


نتائج تحليل المحتوى على أحدى الزميلات، ولحساب ثبات التحليل قامت الباحثة بأجر اء عملية التحليل مرتين بفارق زمني الحني أسبو عين. رابعاً: إعداد دليل المعلمة:

تم أعداد دليل للمعلمة للاسترشاد به في عملية المعلية التدريس وفقاً لاستراتيجية التفكير بصوت مرتفع، ويتضمن الدليل:

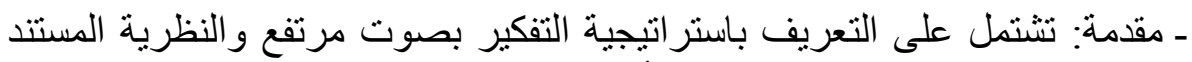
عليها، ونبذه عن مهارات التفكير التأملي والذات الاكاديمية في العلوم، وتوجيهات

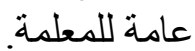
- خطة زمنية بعدد الحصص لتدريس الوحدة المختارة وفقا لاستراتيجية التفكير بصوت مرتفع. ـ الأهداف التعليمية للوحدة. ـ نماذج لخطط تحضير الدروس (اليوم، التاريخ، الأهداف الاجرائية، الوسائل

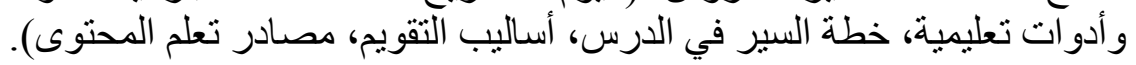

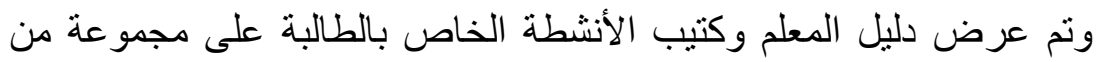

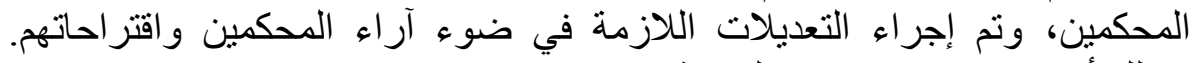
وبذللك أصبحت في صون إجراء تهما النهائية. خامساً: أعداد أوراق نثاط الطالبة:

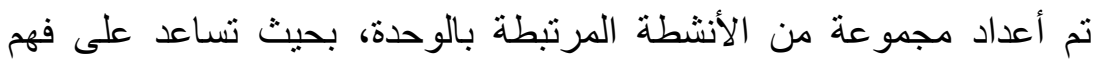

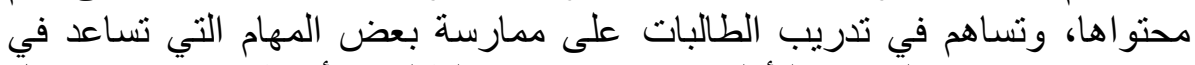

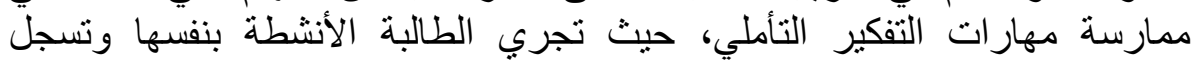
الملاحظات و الاستنتاجات و التفسير ات و الاقتر احات التهات

$$
\text { سـادساً: أدوات الدراسة: }
$$

أـ الههف من الاختبار: يهذف اختبار التفكير التأملي إلى قياس مدى امتلاك التكئ

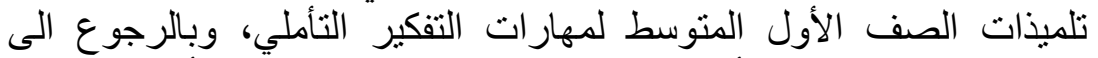

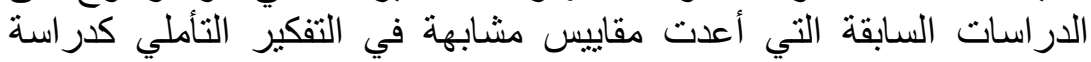

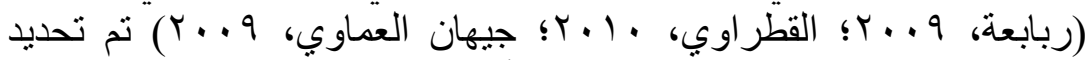

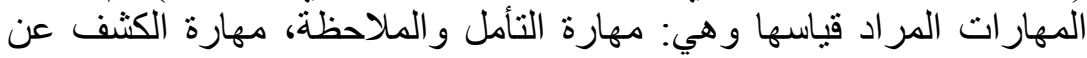

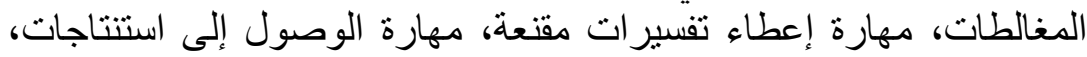

$$
\text { مهارة وضع حلول مقترحة. }
$$

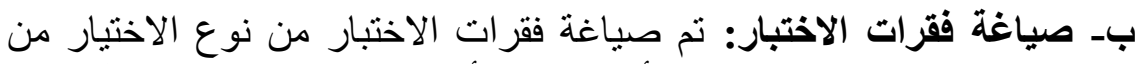

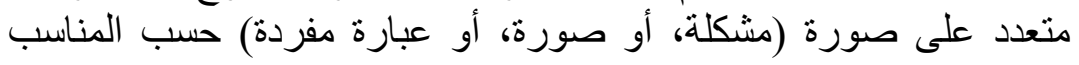


للمحتوى، ويندرج تحتها أربع بدائل مشتقة منها وتقيس إحدى المهارئل إعنات

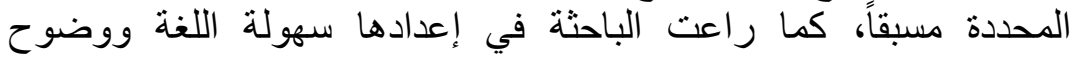
العبار ات، وملائمتها لمستويات التلميذات.

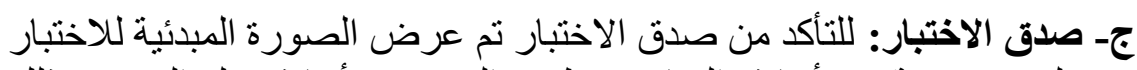

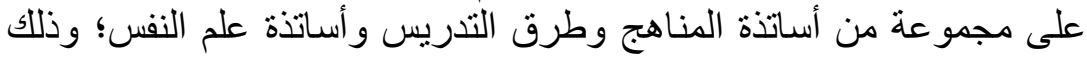

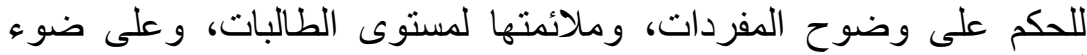
أر اءهم ومقترحاتهم تم إجر اء التعديلات.

دـ التجريب الاستطلاعي للاختبار: طبق الاختبار في صورته الأنه الأولية على عينة

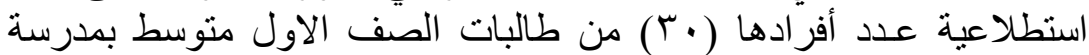

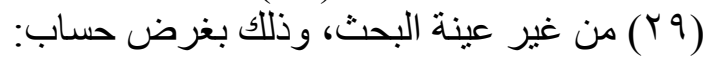

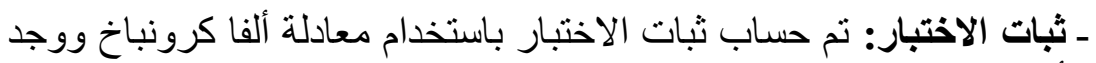

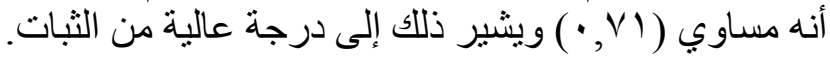

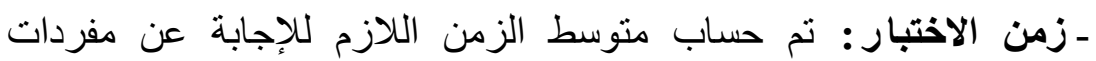

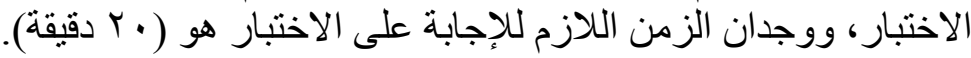

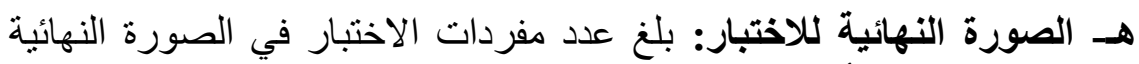

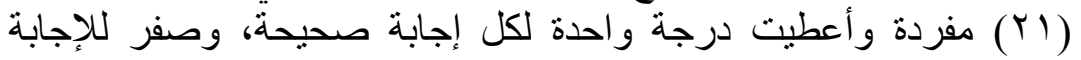

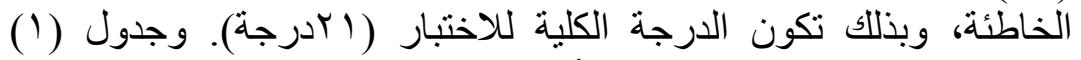
يوضح مو اصفات اختبار التفكير التأملي. جدول (1) مواصفات اختبار التفكير التأملي

\begin{tabular}{|c|c|c|c|c|}
\hline الارجة & الاوزان النسبية & عدد الأسئلة & رقم السؤال & المهارة \\
\hline 7 & 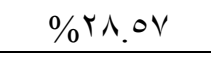 & 7 & $10,11,11,1 \cdot, 7,1$ & التأمل والملاحظة \\
\hline r & $\%) \leq . Y \wedge$ & r & Y), $9, \varepsilon$ & الكشف عن المغالطات \\
\hline$\varepsilon$ & $\% 19 . \varepsilon$ & $\varepsilon$ & $r \cdot, 1 \wedge, 1 \vee, 0$ & إعطاء تفسيرات مقتعة \\
\hline$\varepsilon$ & $\% 19 . \cdot \varepsilon$ & $\varepsilon$ & $17,1 \leq, V, r$ & الوصول إلى استتتاجات \\
\hline$\varepsilon$ & $\% 19 . \varepsilon$ & $\varepsilon$ & $19,14, \Lambda, r$ & وضع حلول مقترحة \\
\hline آبدرجة & $\% 1 \ldots$ & YI & \multicolumn{2}{|c|}{ المجموع } \\
\hline
\end{tabular}

r - أعداد الاختبار التحصيلي:

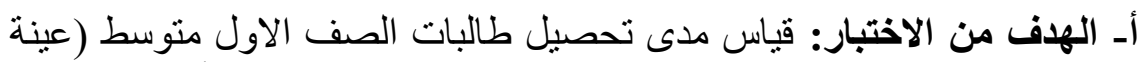

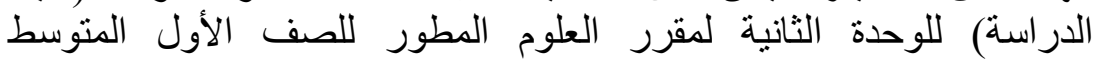

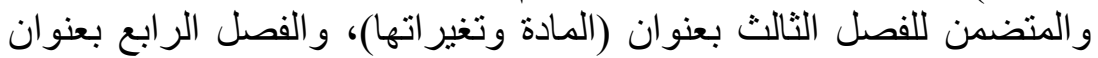

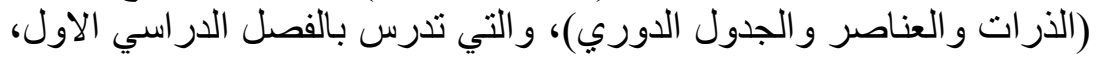
وذلك في المستويات المعرفية التالية: التذكر ــ الفهم- التطبيق. بلتئ. 
بـ صياغة مفردات الاختبار: تمت صباغة مفردات الاختبار على نمط الاختبار

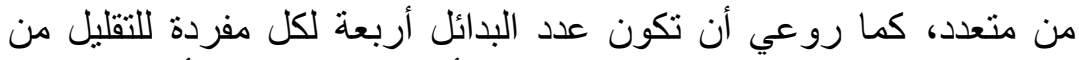

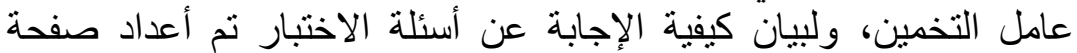
للتعليمات تضمنت البيانات الثخصية للطالبة وكيفية الإجابة عن أسئلة الإنة

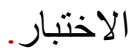

ج- صدق الاختبار: للنأكد من صدق الاختبار تم عرض الصورة المبدئية للاختبار

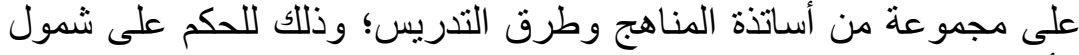

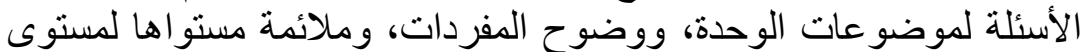

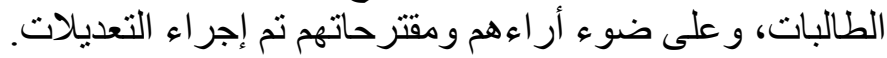

دـ التجريب الاستطلاعي للاختبار: طبق الاختبار في صورته الأولية على عينة

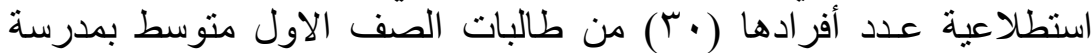

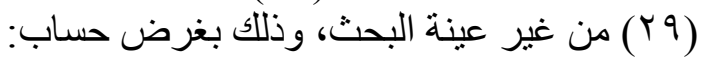

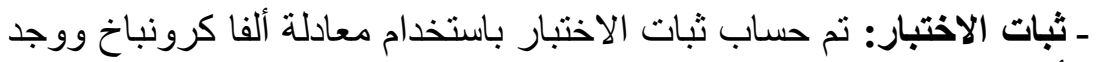

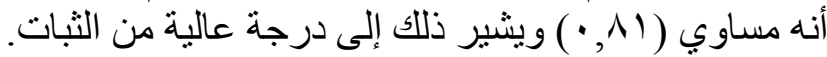

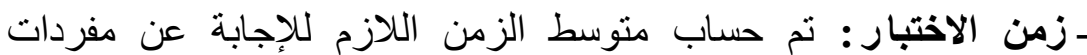

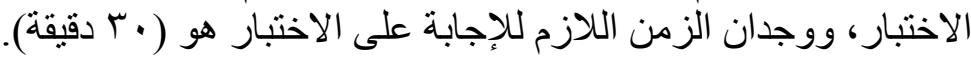

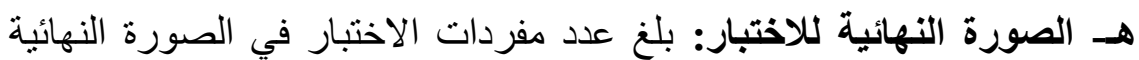

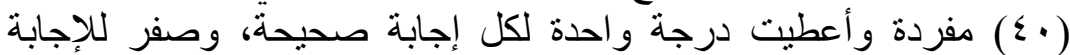

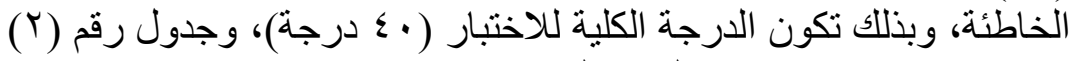
يوضح مو اصفات الاختبار التحصيلي. جدول (Y) يوضح مواصفات الاختبار التحصيلي

\begin{tabular}{|c|c|c|c|c|c|}
\hline \multirow{2}{*}{ المئوية } & \multirow{2}{*}{ المجموع } & \multicolumn{3}{|c|}{ مستويات الأهداف } & \multirow{2}{*}{ الموضوعات } \\
\hline & & تطبيق & فهم & 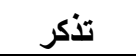 & \\
\hline \% Y Y Y & 1. & 1 & $\varepsilon$ & 0 & الخو اص و التغير ات الفيزيائية \\
\hline$\% 10.740$ & $\circ$ & r & 1 & r & الخو اص و التغير ات الكيميائية \\
\hline$\% \backslash 1 . \vee 0$ & 7 & r & r & r & تركيب المادة \\
\hline$\%$ \% rvo & 11 & r & r & 0 & العناصر و المركبات و المخاليط \\
\hline$\% 1 \ldots$ & m & $\wedge$ & 1. & $1 \varepsilon$ & المجموع \\
\hline & $\% 1 \ldots$ & $\%$ ro & \% r. ro & $\% \leqslant r, v_{0}$ & النسبة المئوية \\
\hline
\end{tabular}


r- مقياس فعالية الذات الاكاديمية في العلوم: لإنية

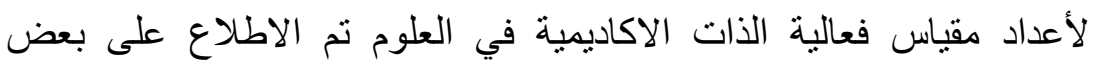

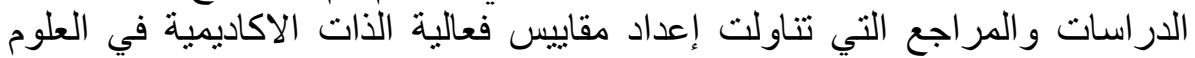

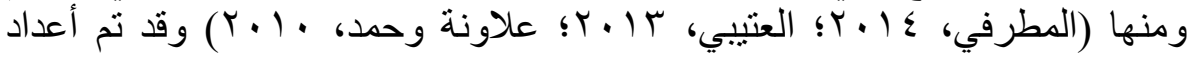
المقياس وفق الإجر اءات التالية:

أـ الهدف من المقياس: يهدف المقياس الى تقدير معتقدات فعالية الذات الأكاديمية في العلوم لدى طالبات المجمو عتين التجريبية و الضابطة.

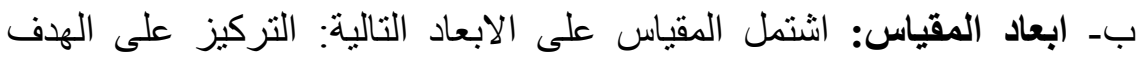

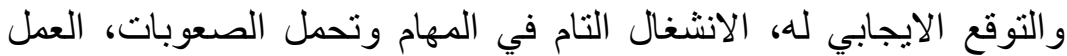
بروح الفريق، التحكم الذاتي و القناعة الذاتية.

ج- صياغة فقرات المقياس وطريقة تصحيحها: تم صياغة عدد من الفقرات تدور

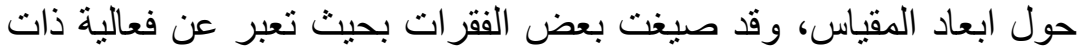

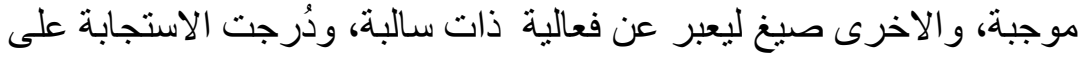
فقرات المقياس تدريجا خماسيا وفق طريقة ليكرت Likert لتحديد درجة

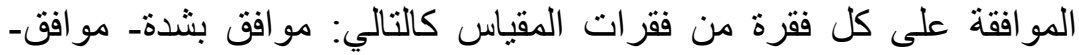

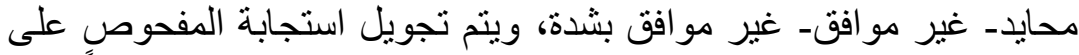

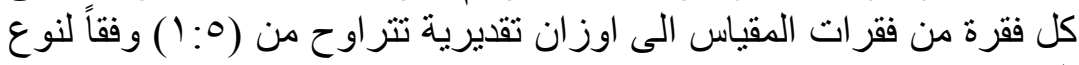

العبارة

د- صدق المقياس: تم عرض الصورة الأولية للمقياس على مجموعة من

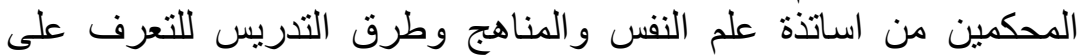

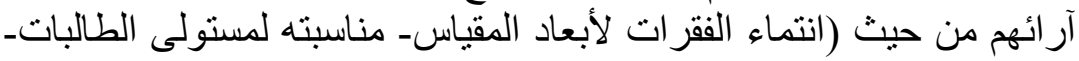
الصحة اللغوية) وتم اجر اء التعديلات في ضوء أراء الهُ المحكمين.

هـ التجريب الاستطلاعي للاختبار: طبق الاختبار في صورته الأولية على عينة

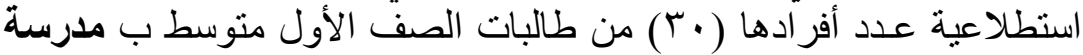

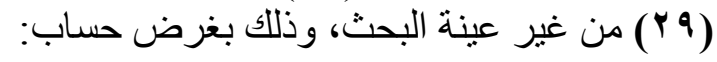

ـ ـ ثبات الاختبار: تم حساب ثبات الاختبار باستخدام معادلة ألفا كرونباخ، ووجد

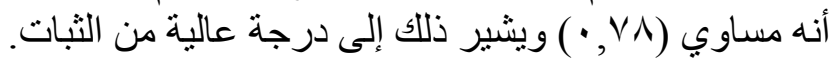

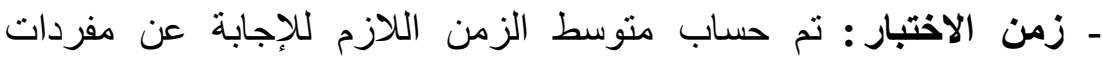

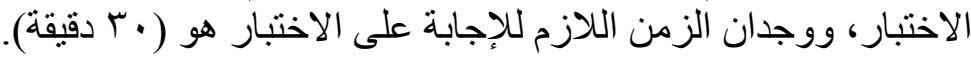

و- الصورة النهائية للمقياس: بلغ عدد مفردات المقياس في الصورة النهائية

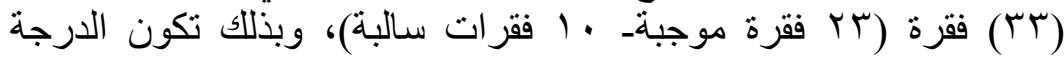

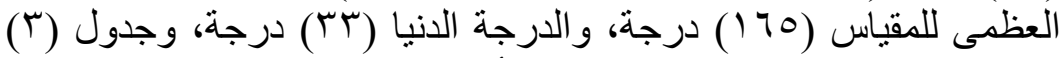
يوضتح مو اصفات مقياس فعالية الذات الأكاديمية في العلوم. 


\begin{tabular}{|c|c|c|c|}
\hline 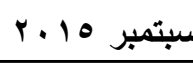 & \multicolumn{2}{|c|}{ المجلا الثامن عشر } & العدد الخامس \\
\hline \multicolumn{4}{|c|}{ جدول (ب) مواصفات مقياس فعالية الذات الأكاديمية في العلوم } \\
\hline \multirow{2}{*}{ المجموع الكلي } & \multicolumn{2}{|c|}{ العبار ات } & \multirow{2}{*}{ ابعاد المقياس } \\
\hline & السالبة & الموجبة & \\
\hline 7 & 7 & $\left.0_{-} \varepsilon_{-} r_{-} r_{-}\right)$ & التركيز على الهدف والتوقع \\
\hline 11 & $\left|V_{-}\right| \tau_{-}\left|0_{-}\right| \leq-1$. & $\left|r_{-}\right| r_{-} \mid 1-q_{-} \Lambda_{-} V$ & الانشغال التام في المهام \\
\hline 0 & $r_{-} r_{1}$ & $r \cdot-19-11$ & العمل بروح الفريق \\
\hline 11 & Mr_t & 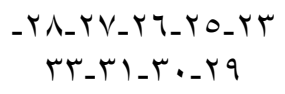 & التحكم الذاتي و القناعة الذاتية \\
\hline س & 1. & rr & المجمو ع الكلى \\
\hline
\end{tabular}

سابعا- إجراءات تطبيق البحث

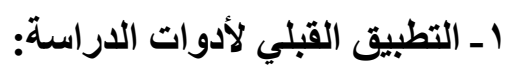

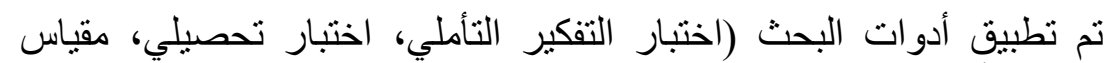

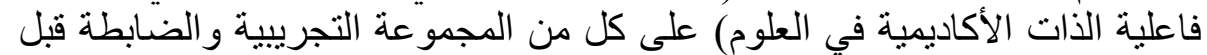

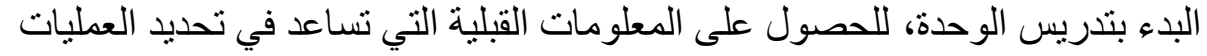

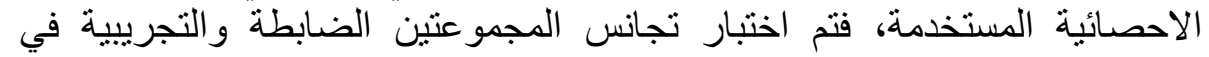

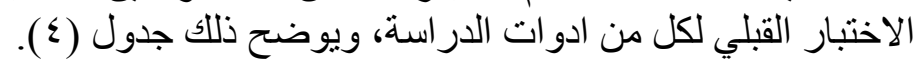

جدول رقم (؛) يوضح تجانس المجمعتين في الاختبار القبلي لكل من اختبار التفكير

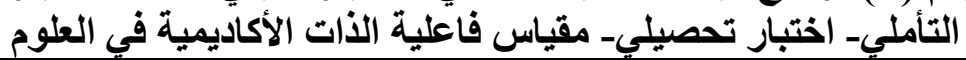

\begin{tabular}{|c|c|c|c|c|c|}
\hline مستوي & قيمة ف & المتوسطات & الحرجية & قيمةت & ادوات الدراسة \\
\hline$\cdot, \wedge \cdot 0$ & $\cdot, \cdot \pi r$ & $\cdot, 1778$ & 01 & •, T0Y & اختبار التفكير التأملي \\
\hline$\cdot$, rot & $1, r 14$ & אזrו, & 01 & $\cdot, \varepsilon \cdot V$ & اختبار التحصيلي \\
\hline$\cdot, T \wedge r$ & $\cdot, l v$. & $\cdot$, rצד & 01 & - $19 \Lambda_{-}$ & الأكقاديمية في العلية الذاتو \\
\hline
\end{tabular}

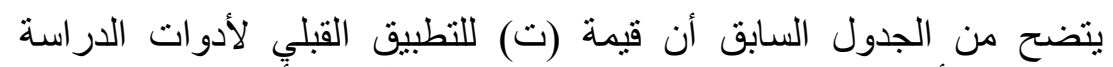

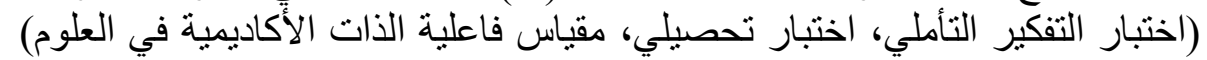

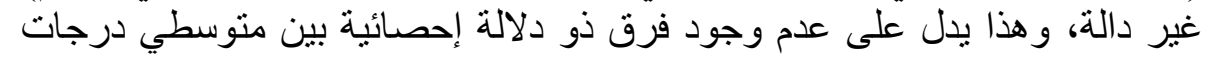

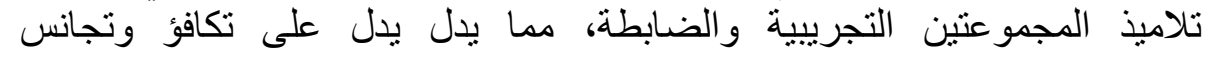


المجموعنين قبل إجر اء التجربة، واستخدام اختبار "ت" (T-TEST) للاختبارات

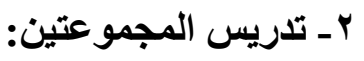

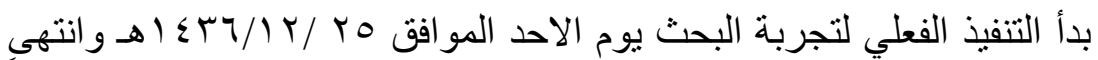

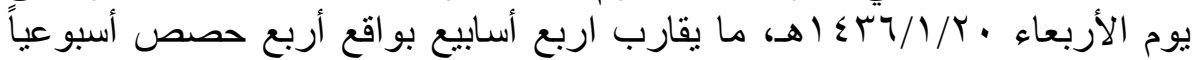

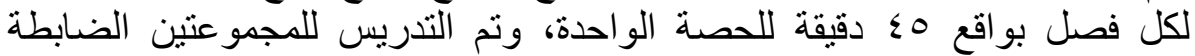

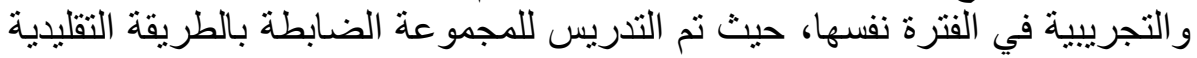
وتدريس المجموعة التجريبية باستخدام استر اتيجية التفكير بصوت لنوت مرتفع. rـ التطبيق البعدي لأداتي البحث:

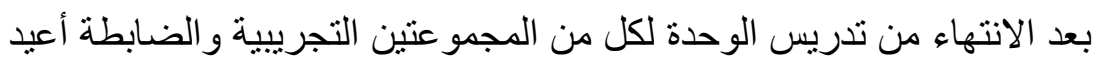

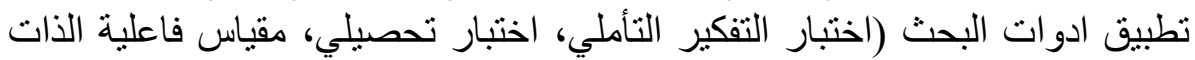

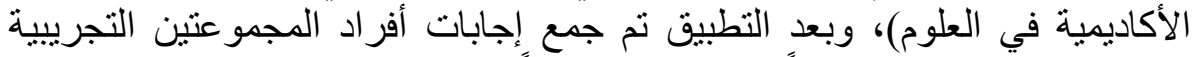
و الضابطة وتم تفريغها تمهيداً لمعالجتها إحصائياً. تحديد الأساليب الإحصائية المستخدمة في معالجة البيانات:

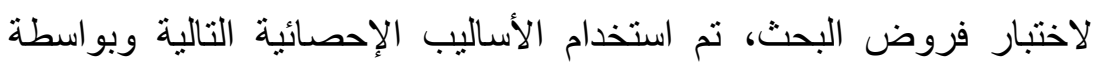

برنامج الرزم الإحصائية للعلوم الاجتماعية Statistical Packages for (SPSS) :Science the Social ـ اختبار (ت) T-Test

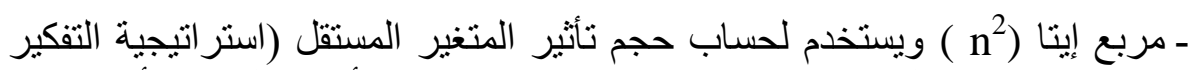

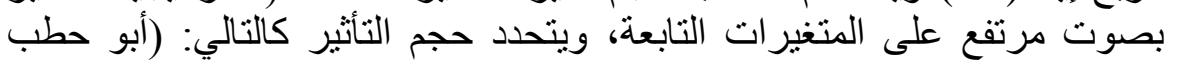
وصادق،

ـ التأثير الذي يفسر حوالي ( ) من التباين الكلي يدل على التأثير ضئيل . ـ التأثير الذي يفسر حوالي ؟ ٪ من التباين الكلي يعد تأثنير أ منوسطاً.

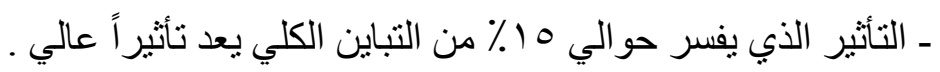

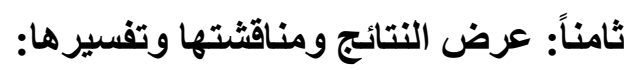
ا ـ النتائج الخاصة باختيار التفكير التأملي: اختبار صحة الفرض الأول:

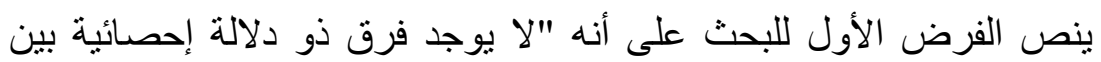

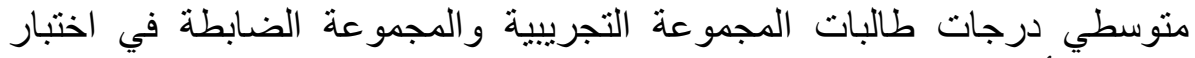
التفكير التأملي الكلي البعدي ومهار اته المختلفة". 
و لاختبار صحة هذا الفرض، تم حساب المتوسطات والانحر افات المعيارية

وقيم (ت) لدرجات تلميذات المجموعتين التجريبية والضابطة في اختبار التفكير

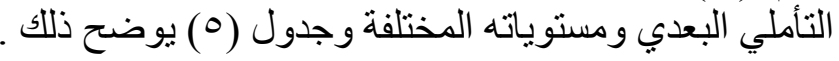

\section{جدول (0)}

المتوسطات والانحرافات المعيارية وقيم (ت) لنتائج التطبيق البعدي لاختبار التفكير

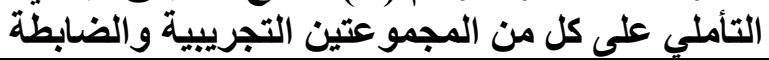

\begin{tabular}{|c|c|c|c|c|c|c|c|}
\hline \multirow[b]{2}{*}{ الاثُ } & \multirow[b]{2}{*}{$\left(n^{r}\right)$} & \multirow[b]{2}{*}{ قيمة (ت) } & \multicolumn{2}{|c|}{ الاتحراف العياري } & \multicolumn{2}{|c|}{ المتوسطات الحسابية } & \multirow[b]{2}{*}{ المحاور } \\
\hline & & & التجريبية & الضجابطوعة المبة & التجريبية & الضجموعة & \\
\hline & & $* \varepsilon, \wedge 19$ & $\cdot, \times 1$ & $\cdot, 71$ & E, & $r, \leqslant v$ & وملاحظة \\
\hline & & *r, qr & $\cdot, 70$ & $\cdot, \leqslant 0$ & $r, r$. & $1, V r$ & كثالطف عن \\
\hline & & r, & $\cdot, \leqslant \Lambda$ & $\cdot, 79$ & سT, & $r, \cdots$ & تفسيرات اعطاء \\
\hline & & $0, v \cdot 1$ & •, Or & $\cdot, 07$ & $r, I V$ & $1, r v$ & الوصتول الى \\
\hline & & 0,771 & $\cdot, 7 \varepsilon$ & $\cdot, \varepsilon r$ & 1,9r & 1,11 & وضع حلول \\
\hline كبير & $\cdot, T Y V$ & $q, q r r$ & 1,01 & 1,99 & $M, \cdot v$ & $q, v$. & الاختبار \\
\hline
\end{tabular}

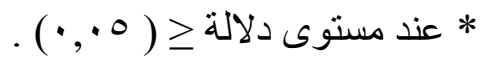

التأمل والملاحظة، الوصول إلى استتناجات، وضع حلول مقترحة، الكثف

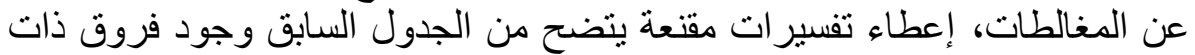

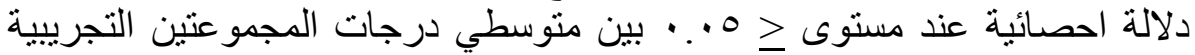

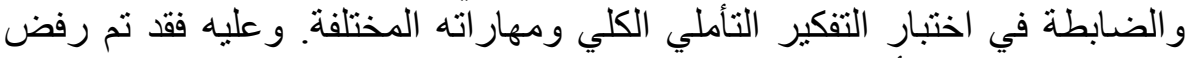

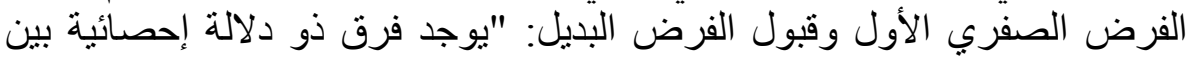

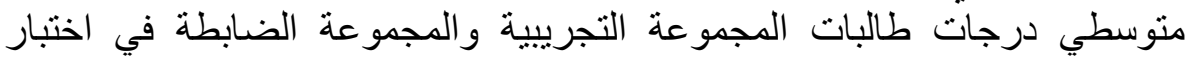
التفكير التأملي الكلي البعدي ومهار اته المختلفة لصالح المجمو عة التجريبية".

ولتقدير حجم فاعلية استر اتيجية التفكير بصوت مرتفع تم حساب مربع إيتا

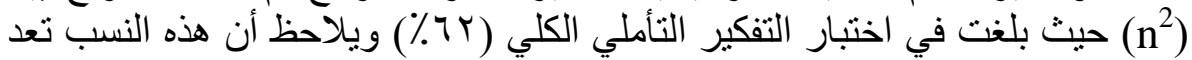

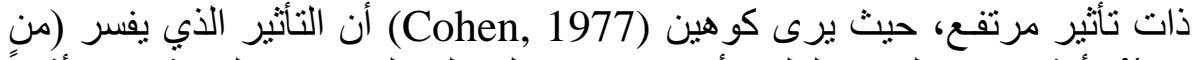

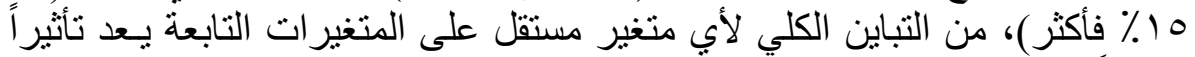

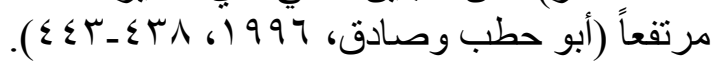


ويمكن تفسير هذه النتيجة أن استخدام استر اتيجية التفكير بصوت مرتفع قد أدى

ـ توفير مناخا تعاونياً يتطلب قيام الطلاب بالعديد من الانشطة التي يمارس خلالها

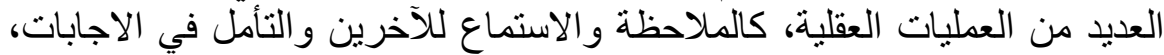

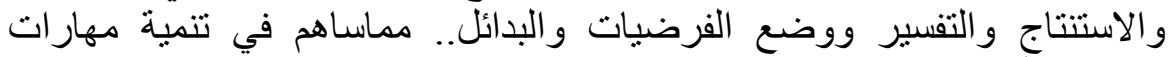
التفكير التأملي.

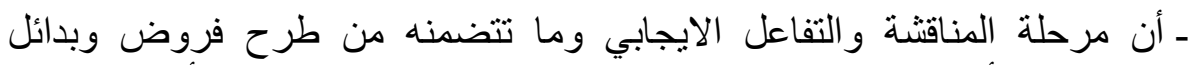

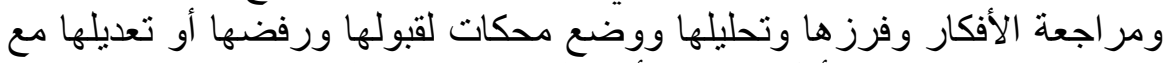
احتر ام ار اء الاخرين وتنامل المو اقف أدى إلى تحسن تلى تلك المهار ات التي تنتظم تحت مظلة التفكير التأملي.

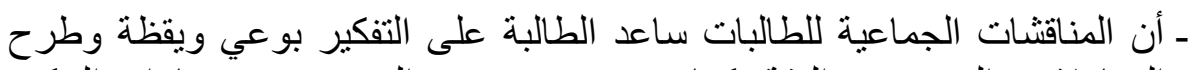

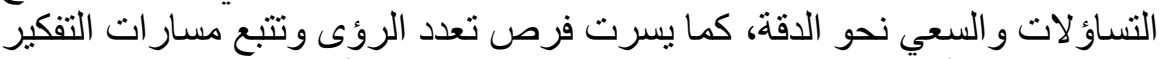
و التحكم فيها الأمر الذي ساهم في تنمية مهار ات التمات التفكير التأملي.

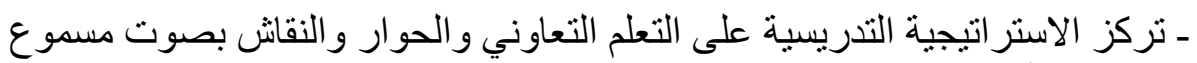

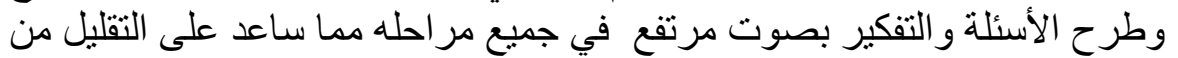

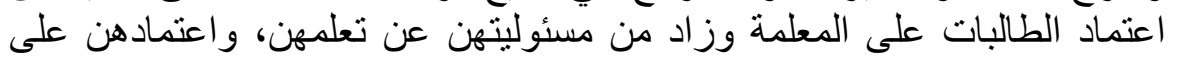

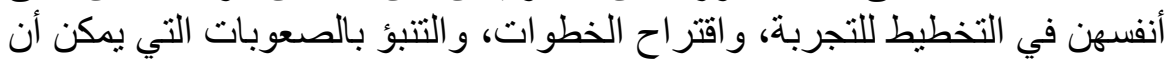

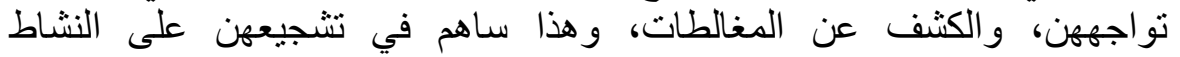

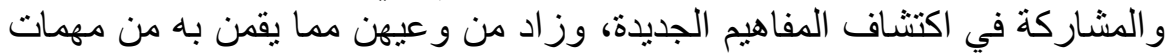
تعليمية، مما ساهم في نمو مهار اتهات التفكير التأملي.

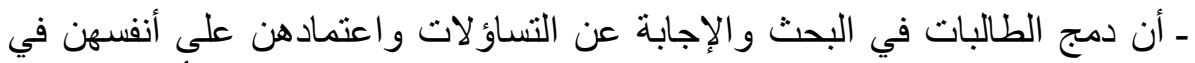

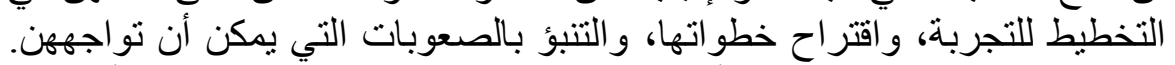

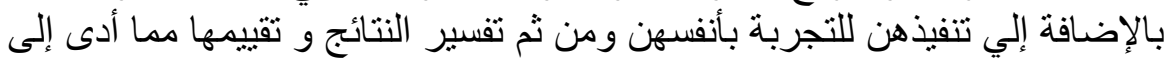

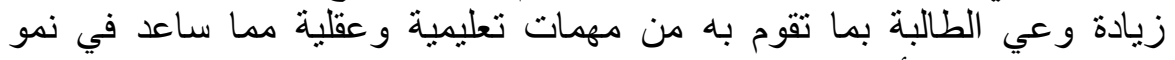

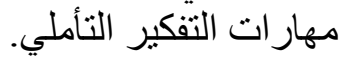

وقد اتفقت هذه النتيجة مع نتائج بعض لدر اسات التي استخدمت استراتيجية

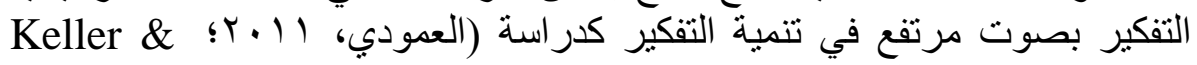

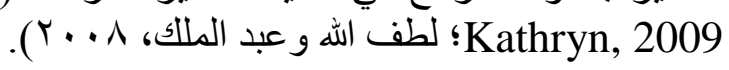

r - النتائج الخاصة بالاختبار التحصيلي.

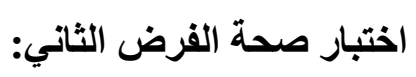

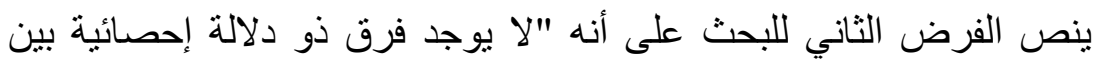

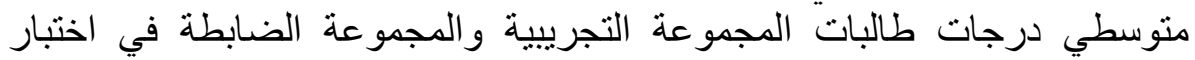
التحصيل الكلي البعدي ومستو ياته المختلفة". 
و لاختبار صحة هذا الفرض، تم حساب المتوسطات والانحر افات المعيارية

وقيم (ت) لدرجات تلميذات المجموعتين التجريبية والضابطة في اختبار التحصيلي

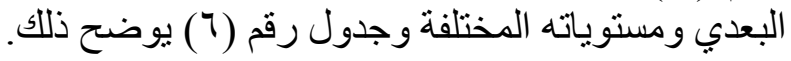

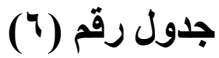

المتوسطات والاتحرافات المعيارية وقيم (ت) لنتائج التطبيق البعدي لاختبار

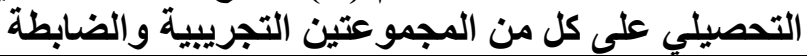

\begin{tabular}{|c|c|c|c|c|c|c|c|}
\hline \multirow[b]{2}{*}{ الاثز } & \multirow[b]{2}{*}{$\left(\eta^{r}\right)$} & \multirow{2}{*}{ ومستوى } & \multicolumn{2}{|c|}{ الانحراف العياري } & \multicolumn{2}{|c|}{ المتوسطات الحسابية } & \multirow[b]{2}{*}{ المحاور } \\
\hline & & & التجريبية التبة & الضجابطوعة المة & التجريبية التجموعة & الضخابطة المة & \\
\hline & & $* 0, V \cdot 1$ & $1, \times 7$ & 1,49 & $q, \varepsilon r$ & $\mathrm{~V}, \mathrm{IV}$ & تذكر \\
\hline & & $* 0, \leqslant 07$ & $1, \cdot v$ & $\cdot, 97$ & $0, V V$ & س & فهم \\
\hline & & $* r, r, 1$ & $\cdot, 7 V$ & 1,11 & $\varepsilon, 7$. & r, & تطبيق \\
\hline المنوسط & $\cdot, 011$ & $* \vee, \wedge \ldots$ & $r,{ }^{\prime} 0$ & r, ro & $19,1$. & $1 \leq, 74$ & الاختبار \\
\hline
\end{tabular}

$$
\text { * عند مستوى دلالة }(0 \text { ( •, •). }
$$

يتضح من الجدول السابق وجود فروق ذات دلالة احصائية عند مستوى × 0

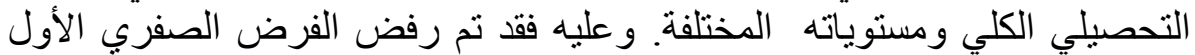

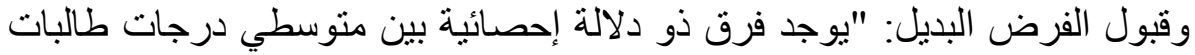

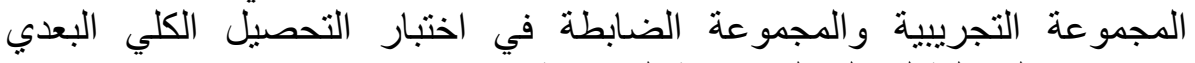
ومستوياته المختلفة لصالح المجمو عة التجريبية".

ولتقدير حجم فاعلية استر اتيجية التفكير بصوت مرتفع تم حساب مربع إيتا حيث بلغت في اختبار التفكير التأملي الكلي (101)

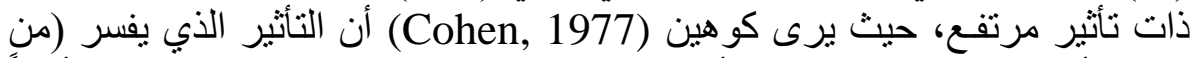

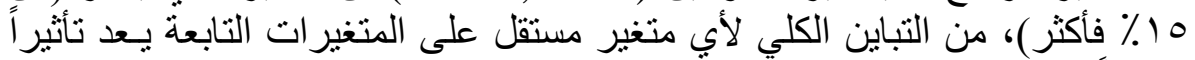

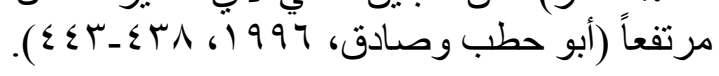
ويمكن تفسير هذه النتيجة أن استخدام استر اتيجية التفكير بصوت مرتفع قد أدى أسى

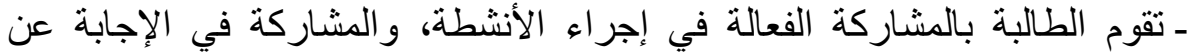

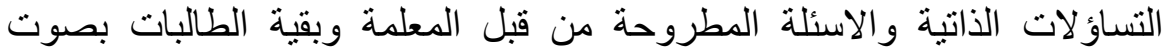
مسموع ومرتفع، الأمر الذي أدى إلى إيجابية المتعلم وتوظيفه لخبرات التئة التعلم 


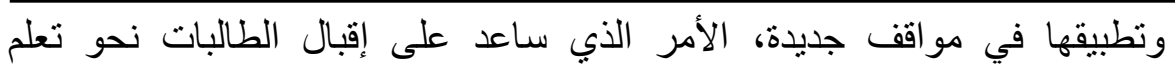

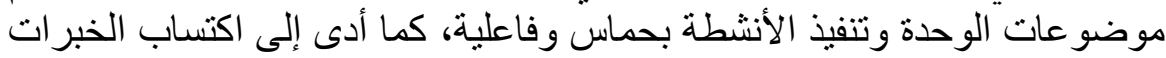

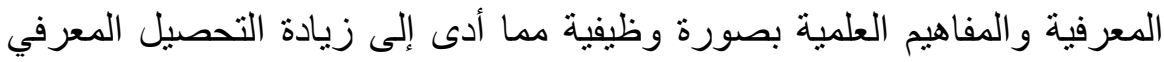

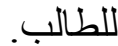

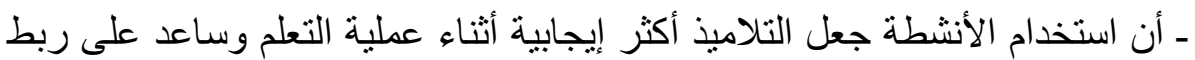

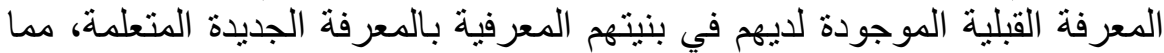
جعل التعلم ذا معنى لديهم وساعدهم على الفهم العميق للمادة المتعلمة.

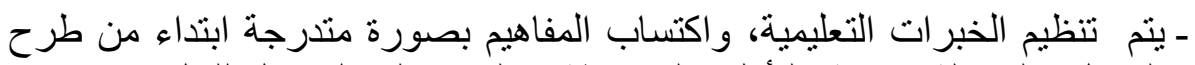

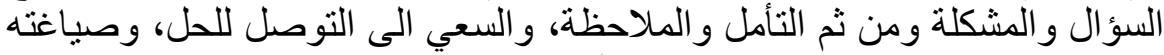

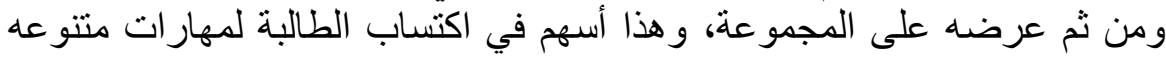

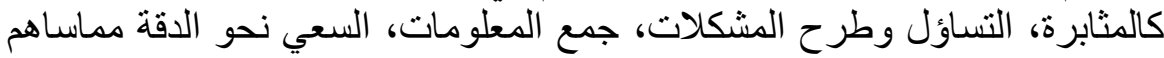
في رفع التحصيل المعرفي.

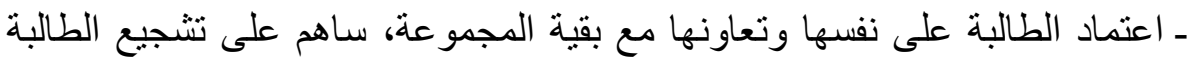

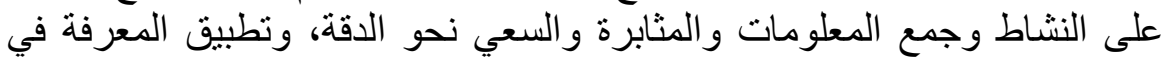
مو اقف جديدة مما ساهم في زيادة التحصيل المعرفي.

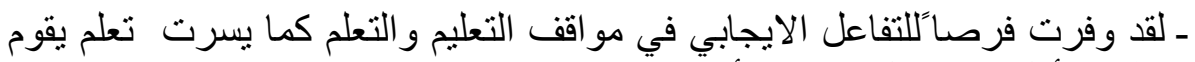

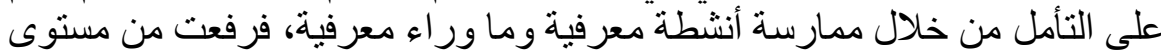

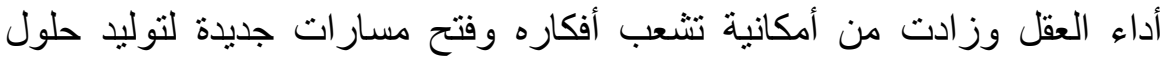

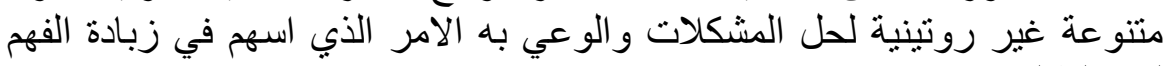

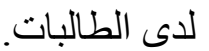

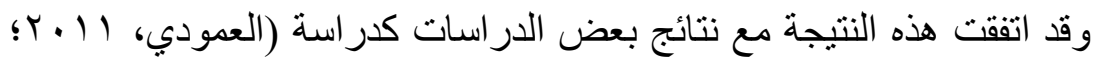

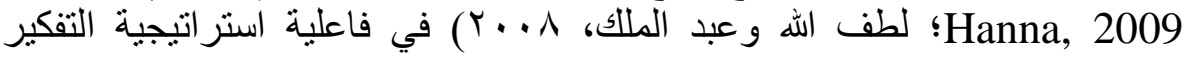
بصوت مرتفع في تنمية التحصيل الدراسي لطالبات المجموعة التجريبية. r- النتائج الخاصة بمقياس فعالية الذات الاكاديمية في العلوم:

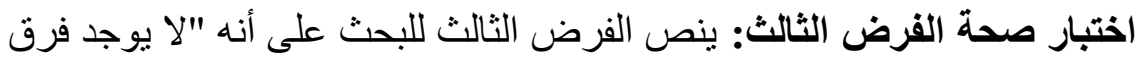

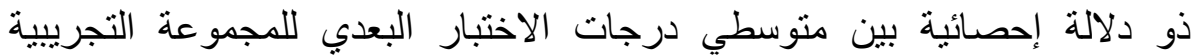

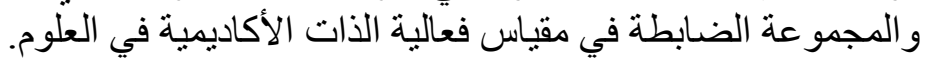

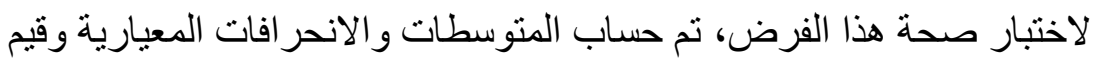
(ت) لارجات طالبات المجموعتين التجريبية والضابطة في فعالية الذات الاتوات الاكاديمية

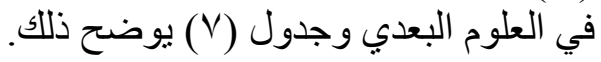




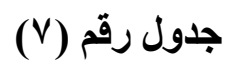

المتوسطات والاتحر افات المعيارية وقيم (ت) لنتائج التطبيق البعدي لمقياس فعالية المباتية

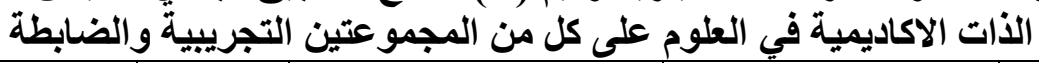

\begin{tabular}{|c|c|c|c|c|c|c|c|}
\hline \multirow{2}{*}{$\frac{1}{x}$} & \multirow[b]{2}{*}{$\left(\eta^{r}\right)$} & \multirow[b]{2}{*}{ قيمة (ت) } & \multicolumn{2}{|c|}{ الانحراف العياري } & \multicolumn{2}{|c|}{ المتوسطات الحسابية } & \multirow[b]{2}{*}{ الاختبار } \\
\hline & & & التجريبية & الضابطة المجة & التجزيبية & الضابطة المجة & \\
\hline & & $r, 7 / 7$ & $r, \cdot v$ & $r, I V$ & $r r, q$. & $r, \varepsilon$. & على الهذف \\
\hline & & $\Lambda, r \vee q$ & $\varepsilon, \wedge 7$ & $\varepsilon, \mu q$ & $\varepsilon \varepsilon, r \pi$ & $r \varepsilon, \mu r$ & الانشغال \\
\hline & & 7,940 & $1, r V$ & $1, \leqslant 1$ & $r), q$. & $19, \leqslant r$ & العروح \\
\hline & & 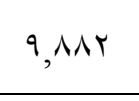 & $0, \cdot 0$ & $0, r \varepsilon$ & $\varepsilon V, T$. & $r \leqslant, \varepsilon V$ & الذاتحي \\
\hline كبير & $\cdot, v \cdot 0$ & $11, \vee \vee \vee 9$ & $1 \cdot, \cdot 1$ & $\Lambda, r r$ & Irv, & $1.9,7 \pi$ & الاختبار \\
\hline
\end{tabular}

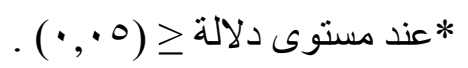

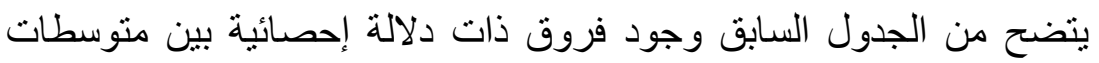

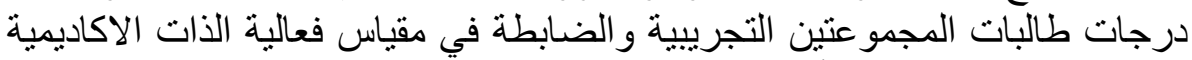

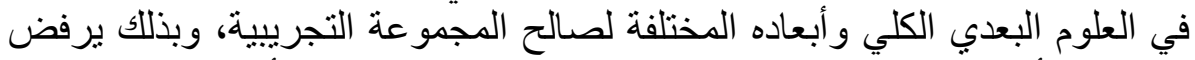

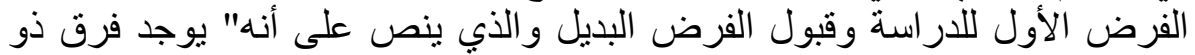

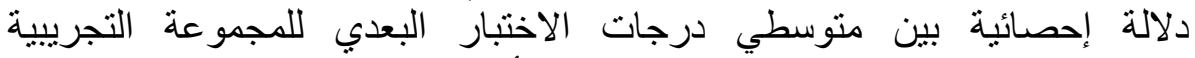

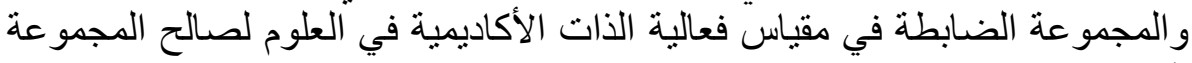

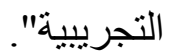

ولتقدير حجم فاعلية استر اتيجية التفكير بصوت مرتفع تم حساب مربع إيتا

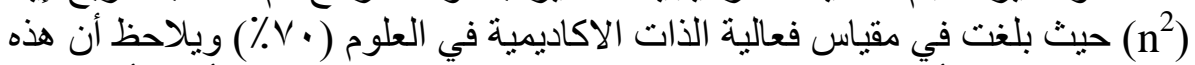

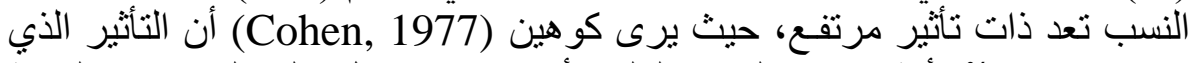

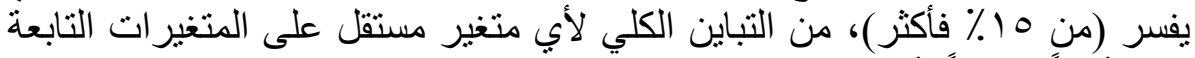

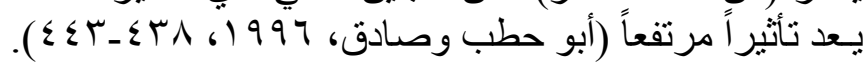

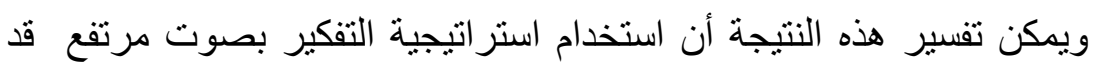

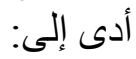




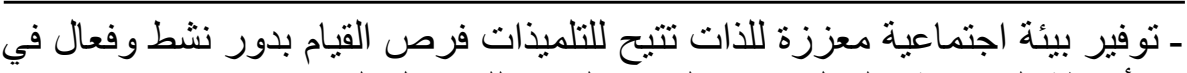

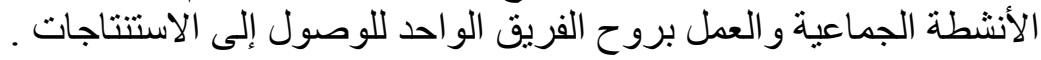

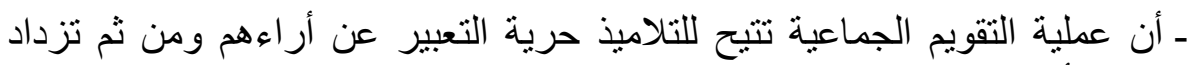

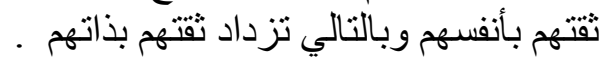

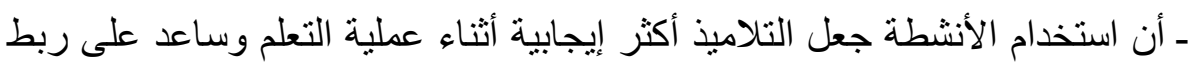

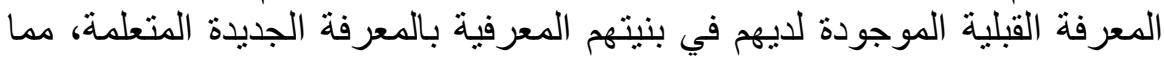
جعل التعلم ذا معنى لايهم وساعدهم على الفهم العميق للمادة المتعلمة.

ـ مواجهة الطالبة بأنتطة تتطلب منها التخطبط المسبق والتنفيذ وتقييم النتائج الأمر

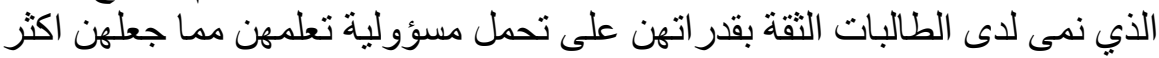

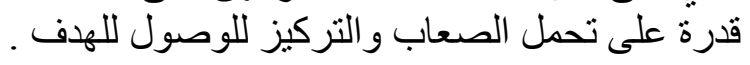

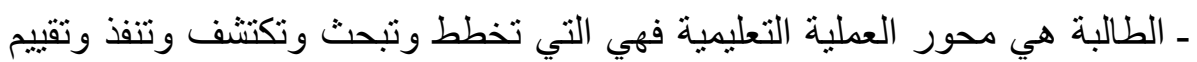

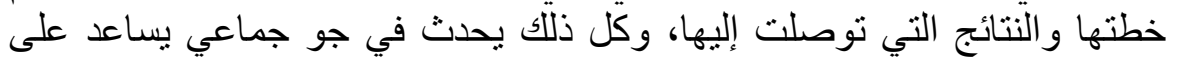

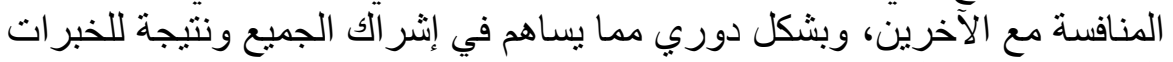

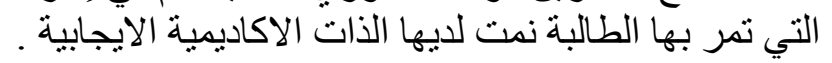

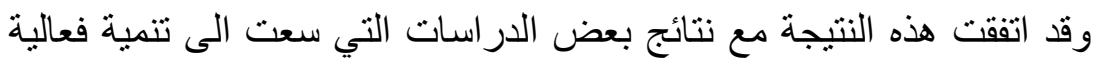

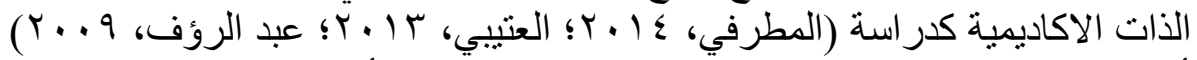

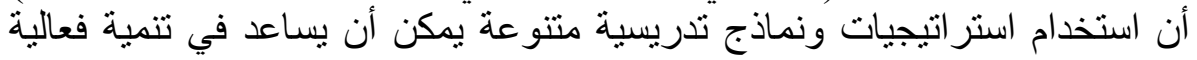

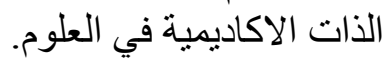
تاسعاً: توصيات الار اسـة: في ضوء ما أسفر عنه البحث الحالي من نتائج، يُوصى بما يلي:

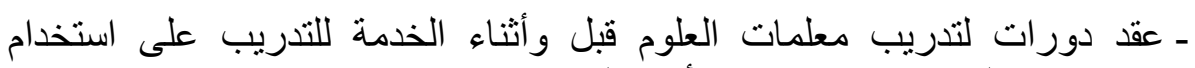
استر اتيجية التفكير بصوت مرتفع أثناء التدريس.

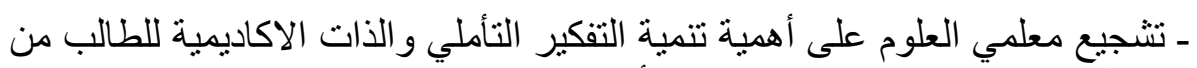

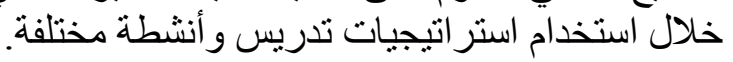

ـ تطوير برامج إعداد معلمي العلوم بكليات التربية بحيث نشتئمل على مثلى مداخل

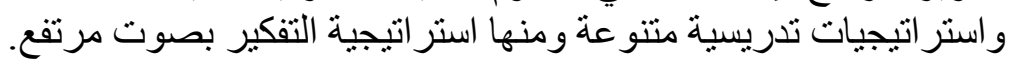
مقترحات الدراسة: كما تقترح الباحثة اجر اء الدر اسات التالية:

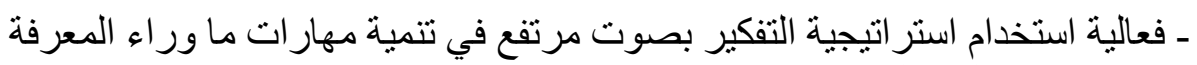

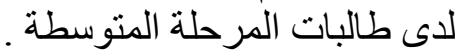

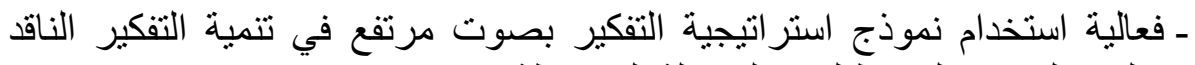

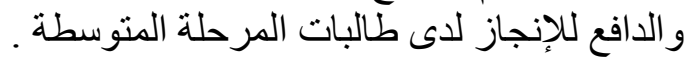


ـ فعالية استخدام استر اتيجيات ونماذج أخرى لقياس فعاليتها في تتمية التفكير التأملي

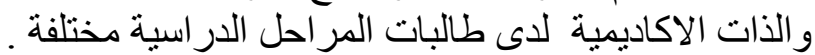

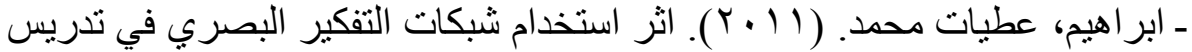

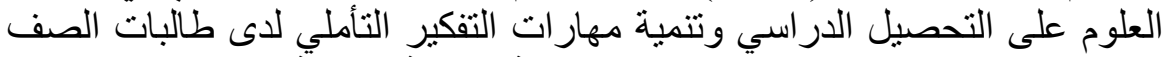

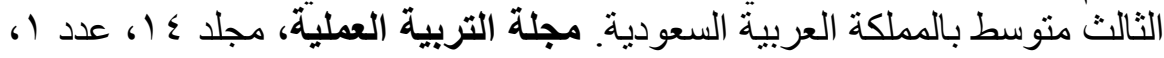

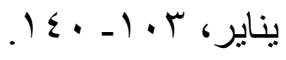

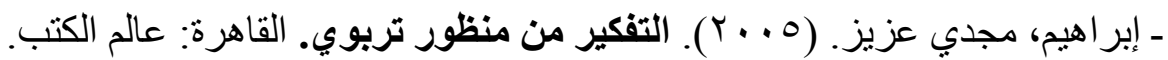

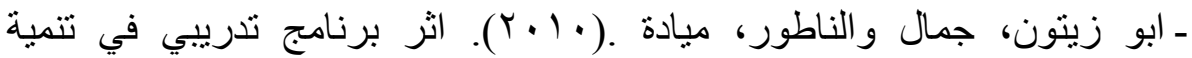

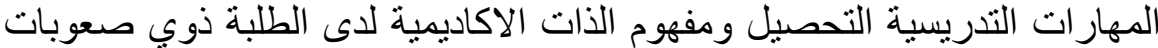

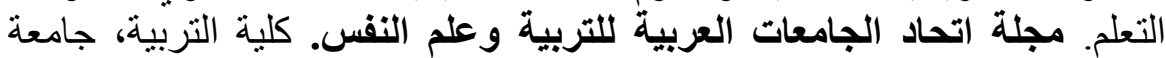

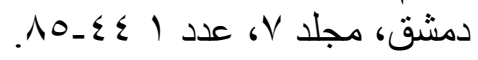

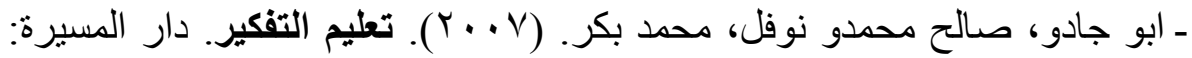

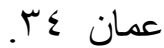

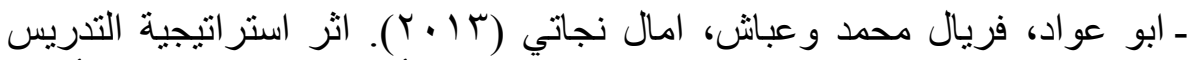

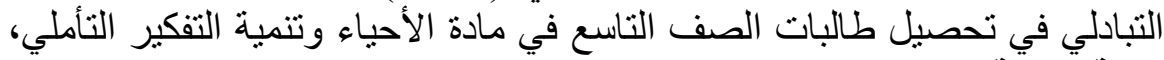

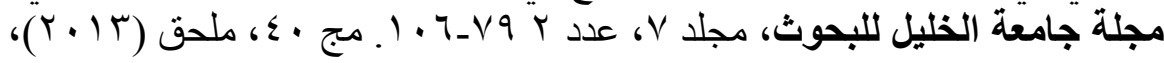

.) $\leqslant \varepsilon .-1 \leqslant r$.

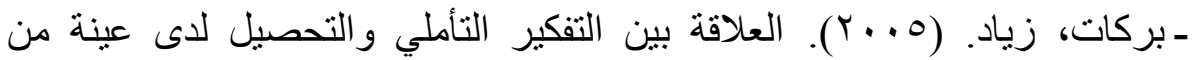

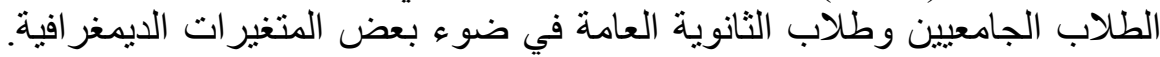

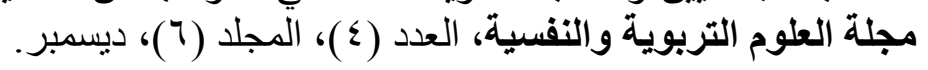

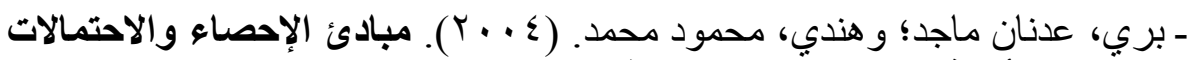
مع حل الأمثلة باستخدام ميكروسوفت إكسل. الطبعة الرابعة، الرياض: مكتبة الاحتبة الثقري.

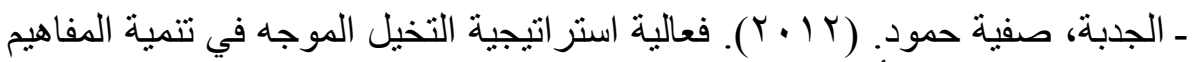

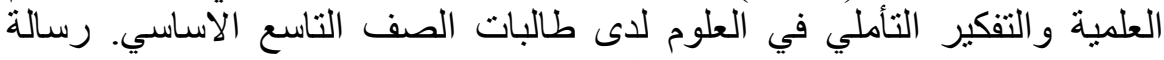

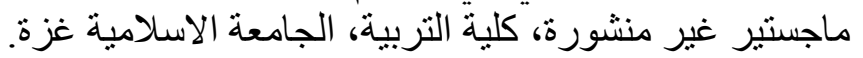

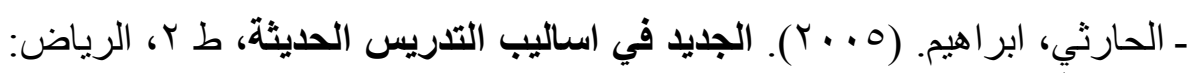

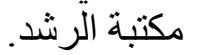

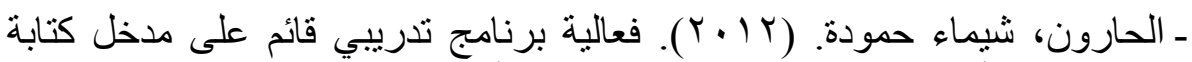

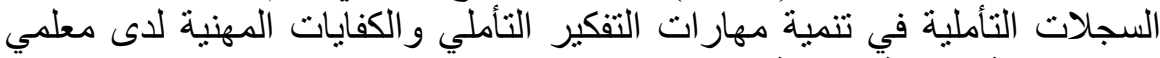

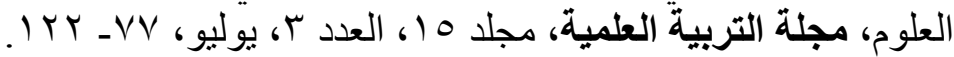




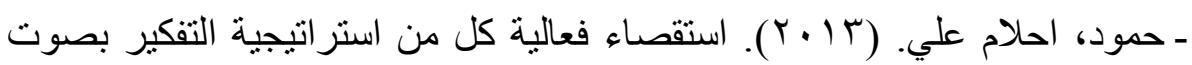

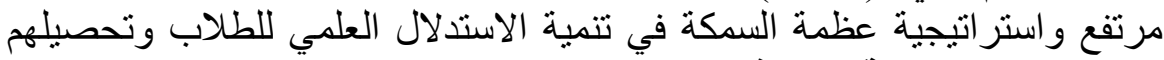

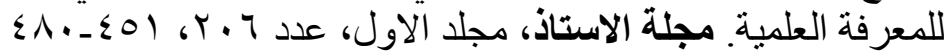

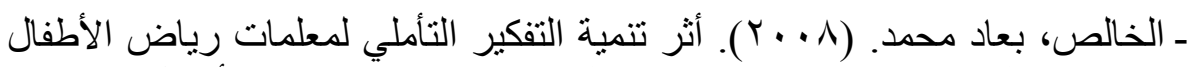

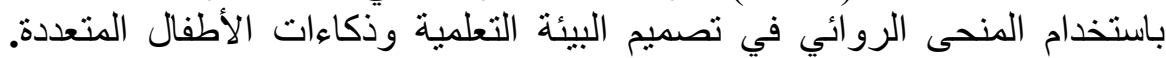

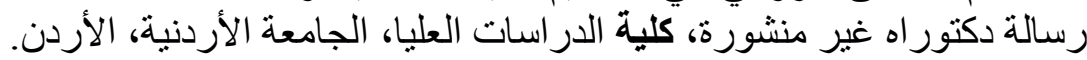

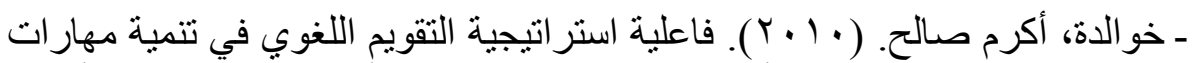

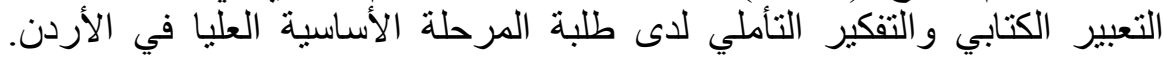

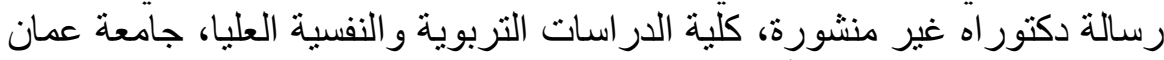
العربية للار اسات العليا، الأردن.

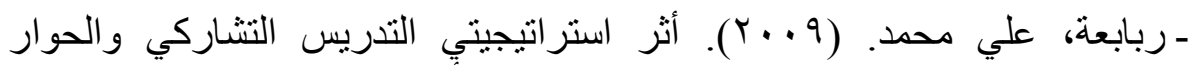
و الطريقة الاعتيادية في التحصيل وتتمية التفكير التأملي في مبحث التئ التربية الإسلامية

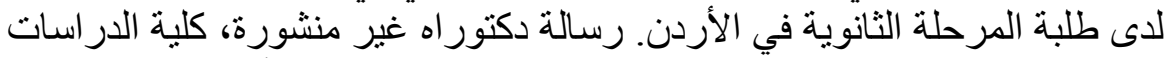

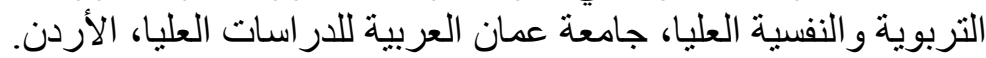

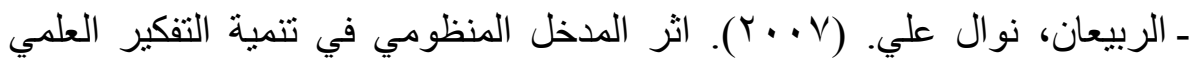

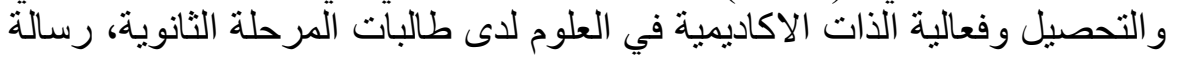
دكتور اه غير منشوره، كلية التربية، جأمعة الرياض.

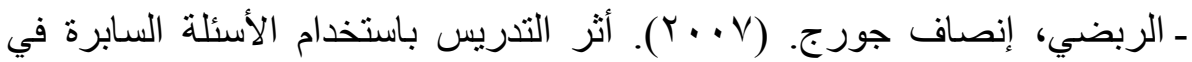

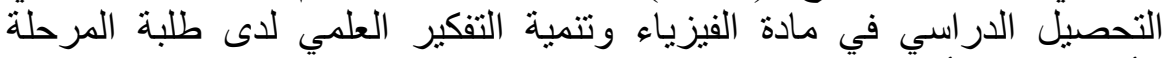

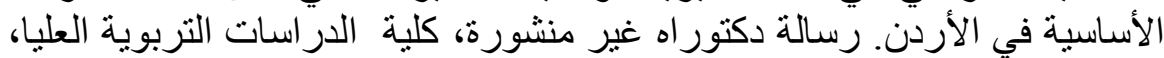
جامعة عمان العربية للار اسات العليا، الأردناه

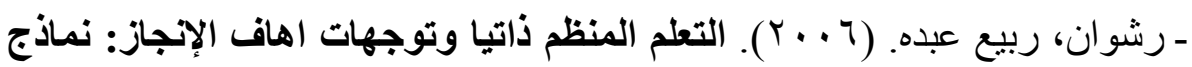
ودراسات معاصرة، القاهرة: عالم الكتب.

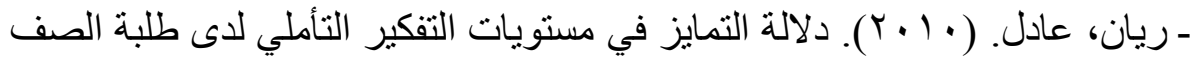

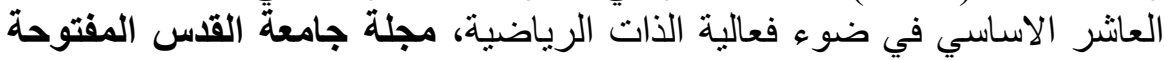

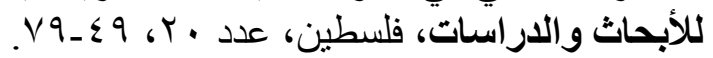

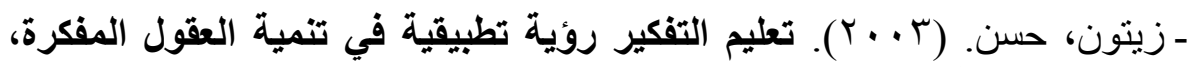

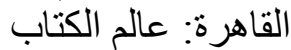

- زيتون، كمال عبدالحميد. (9 . . ب). التدريس نماذجه ومهاراته، القاهرة: عالم

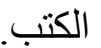

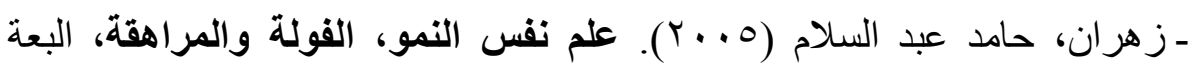

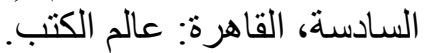




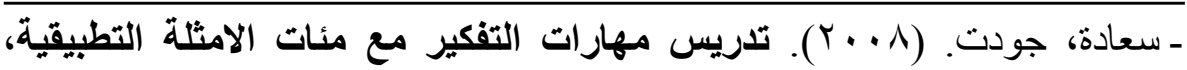

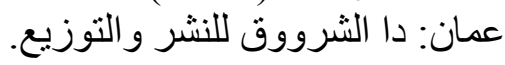

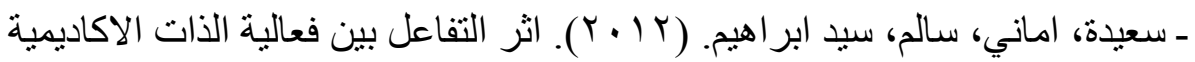

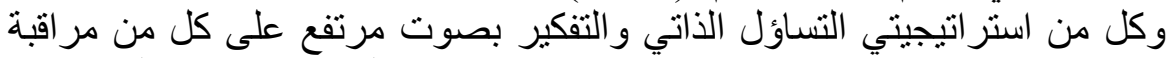

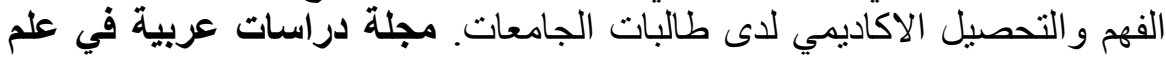

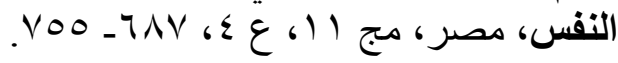

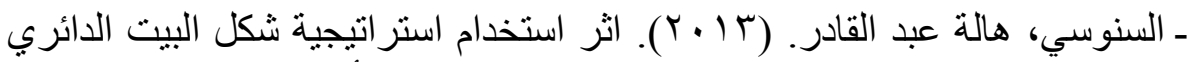

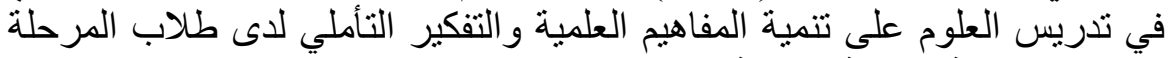

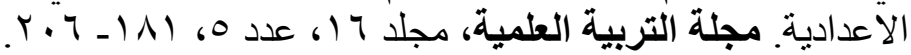

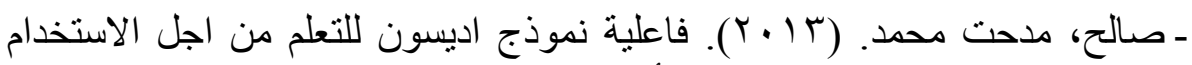

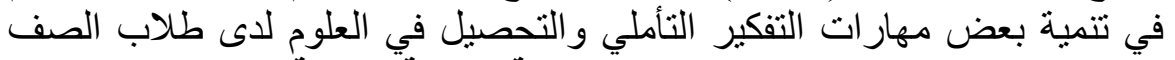

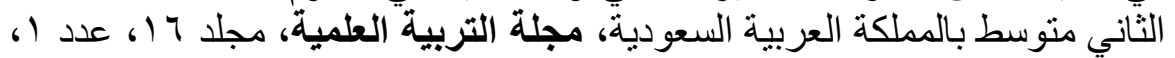

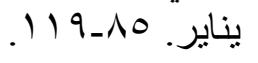

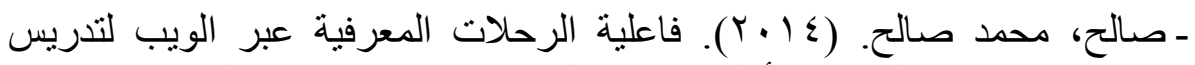

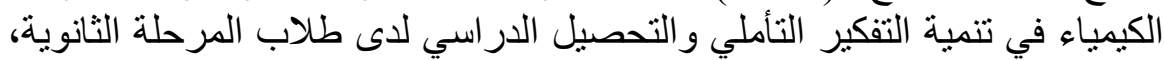

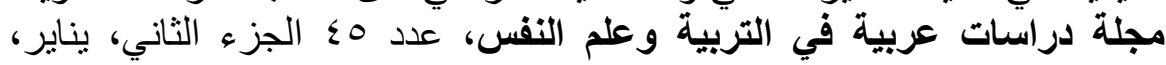
IVA - IrV

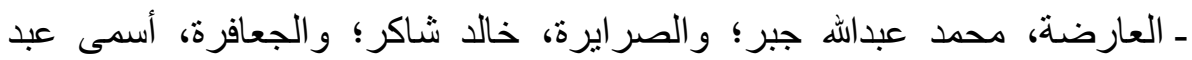

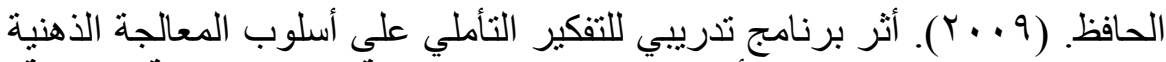

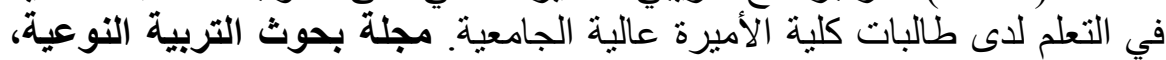

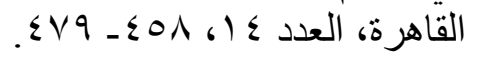

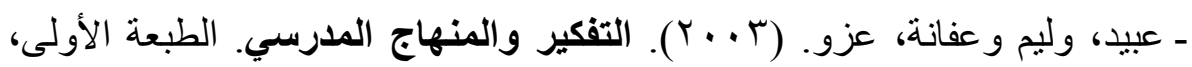

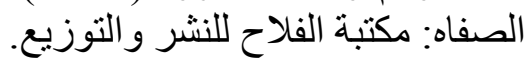

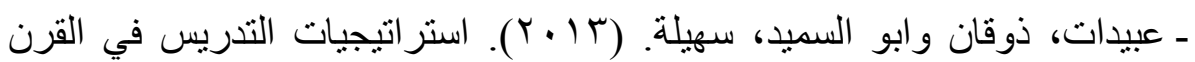
الحادي والعشرين، دركز ديون العيونو لتعليم التفكير : الأردن

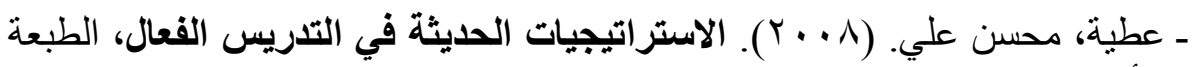
الأولى، عمّان: دار صفاء للنشر و التوزيع.

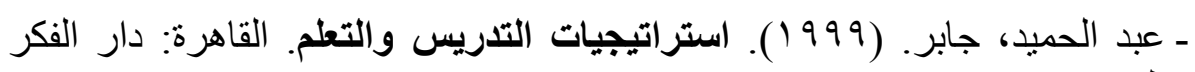
التربوي

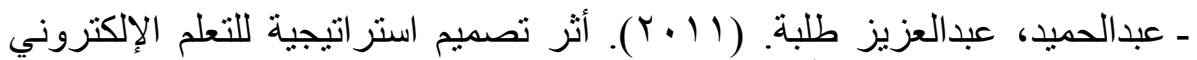

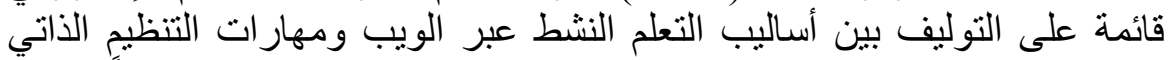
للتعلم على كل من التحصيل و استرانيجيات التعلم الإلكتروني المنظم ذاتياً وتنميةً 


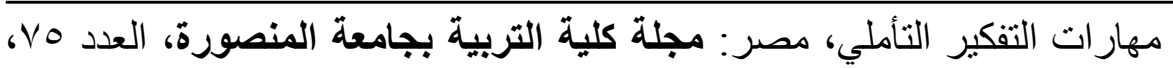

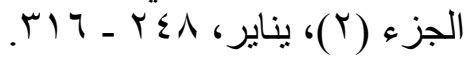

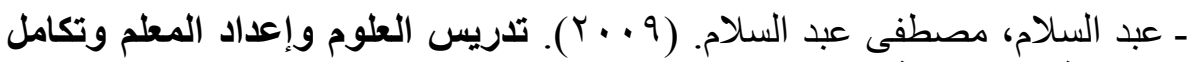
النظرية والممارسة. القاهرة: دار الفكر العربي.

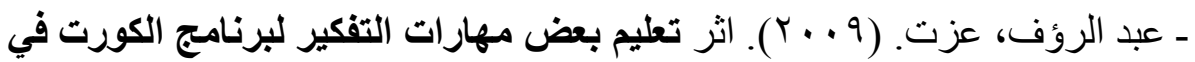

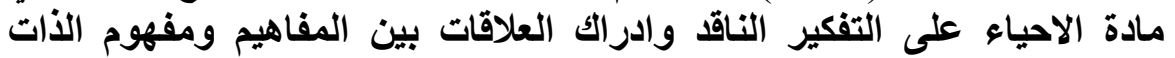

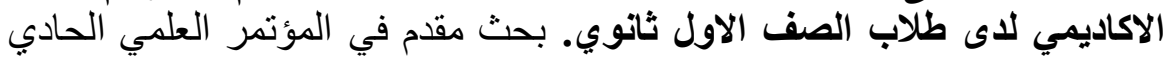

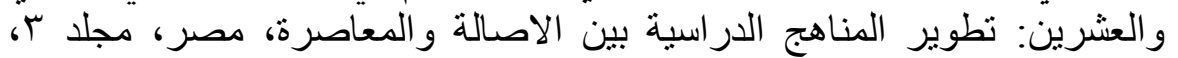
.1. r r

- عبد الهادي، نبيل ومصطفي، نبيل. (1 (ب). التفكير عند الاطفال، عمان: دار

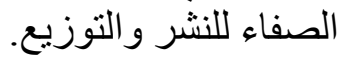

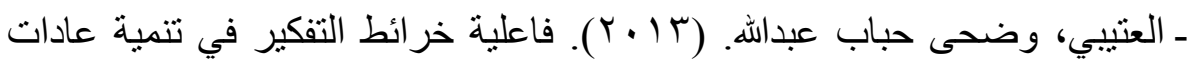

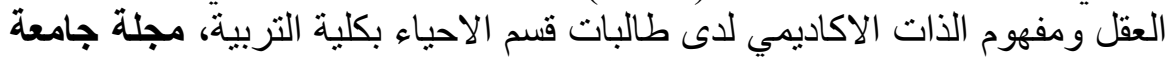

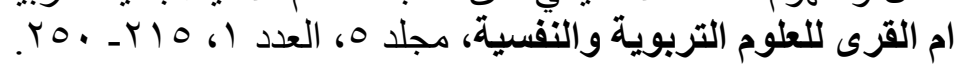

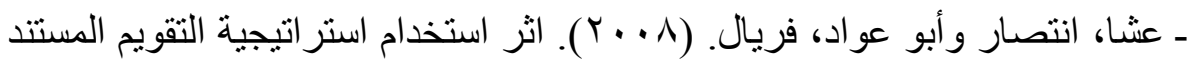

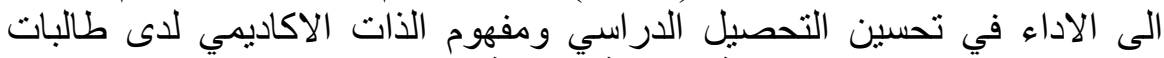

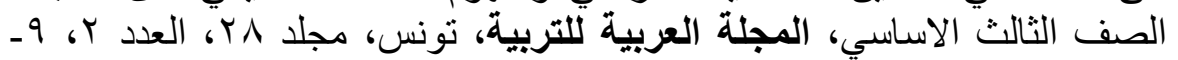

rV

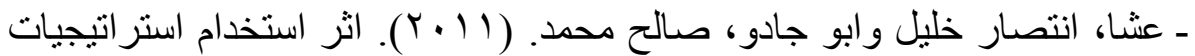

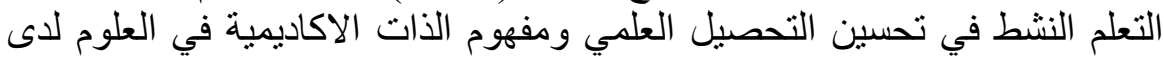

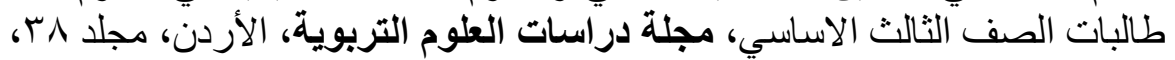

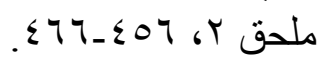

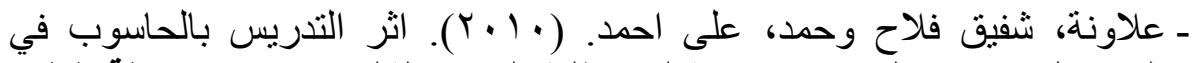

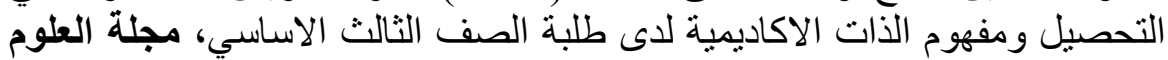

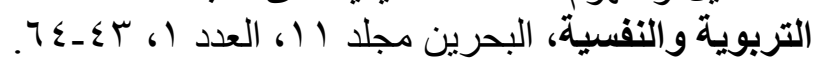

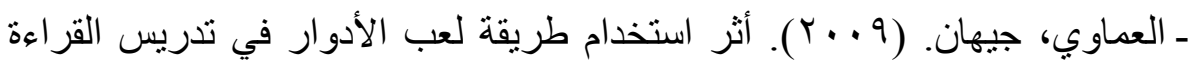

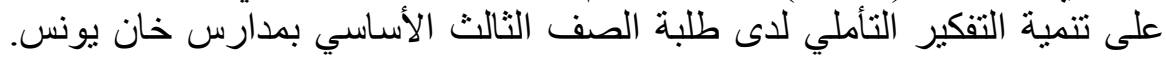
رسالة ماجستير غير منشورة، كلية التربية، الجامعة الإسلامية بغزة، فلسطية الإنين.

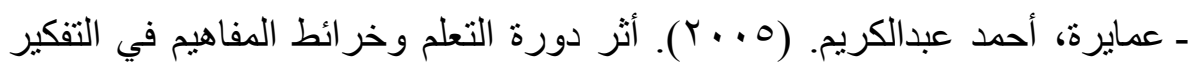

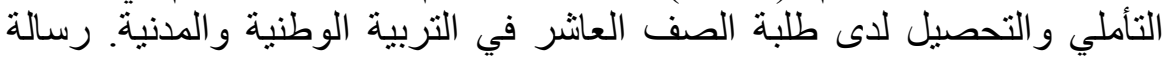
دكتور اه غير منشورة، كلية التربية، جامعة اليرمولك، الأردن.

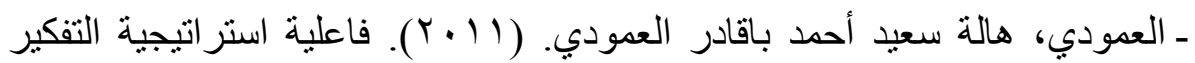
بصوت مرتفع في تتمية التفكير الاستدلالي والتحصيل في مادة العلوم والاتجاه نحو 


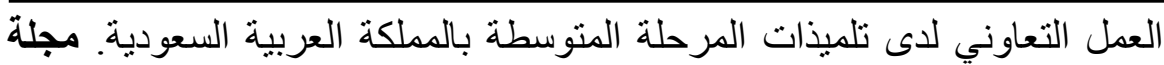

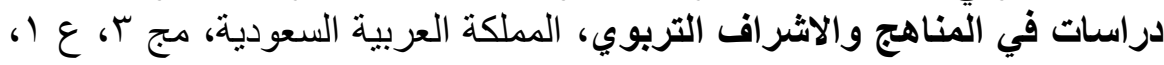

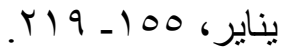

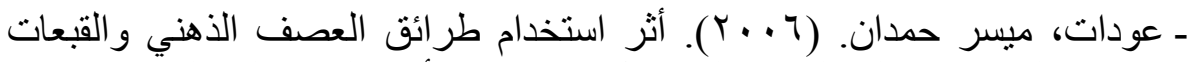

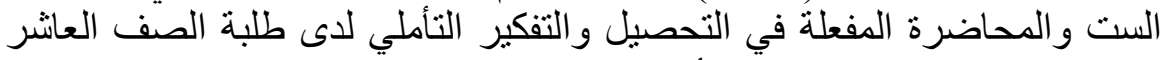

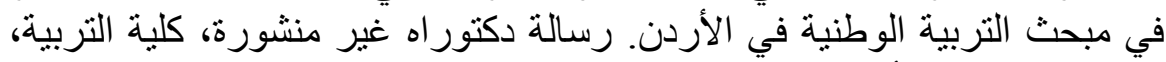

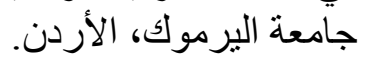

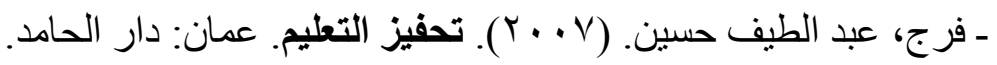

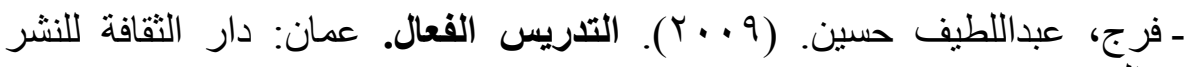
والتوزيع.

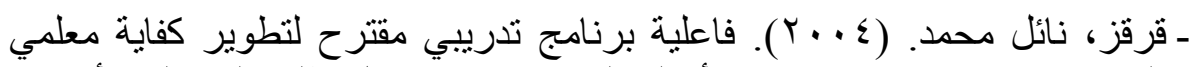

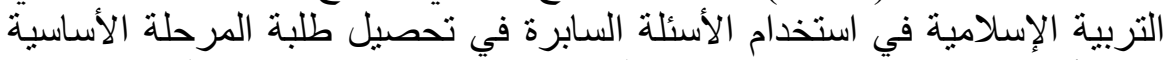

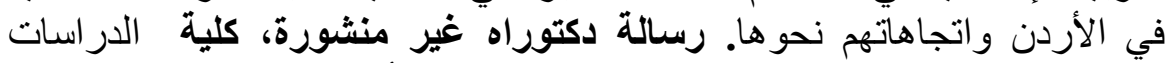
التربوية العليا، جامعة عمان العربية للاند استات العات العليا، الأردن.

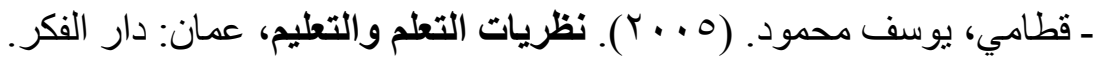

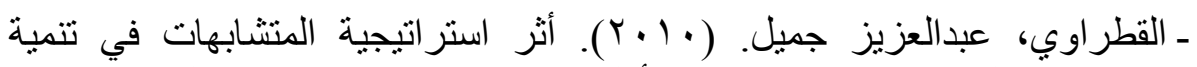

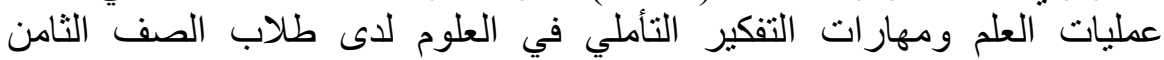
الأساسي. رسالة ماجستير غير منشورة، كلتية التربية، الجامعة الإنيرة الإسلامية بغزه، فلسطين.

ـ لطف الله، نادية سمعان و عبدالملك، لوريس اميل. (1 . . ب). مقرر مقترح ب البيئة

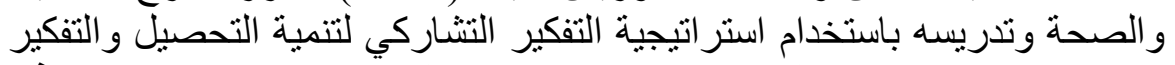

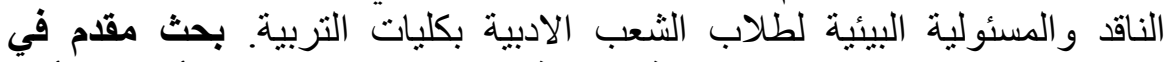

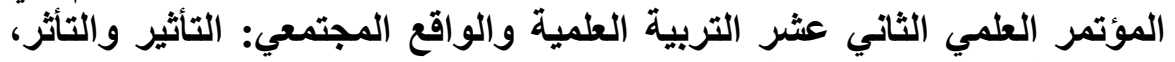

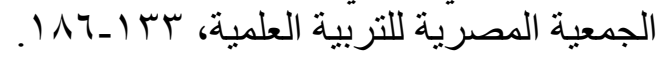

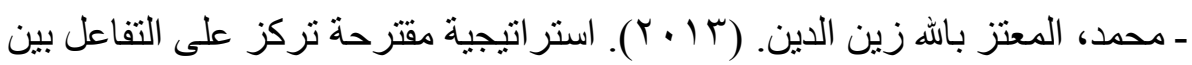

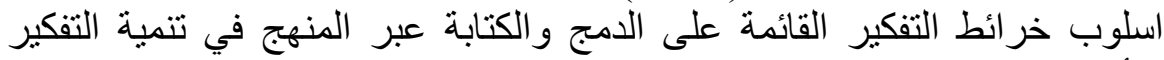

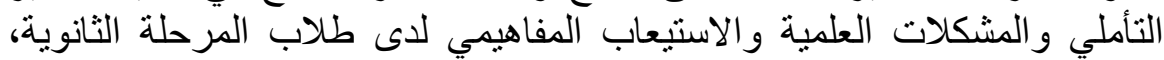

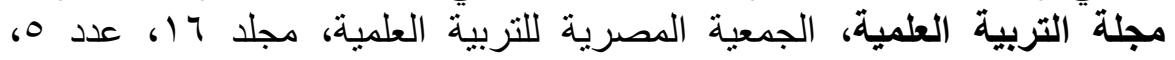

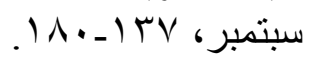

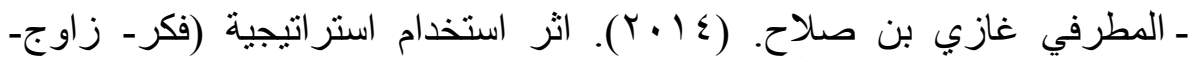

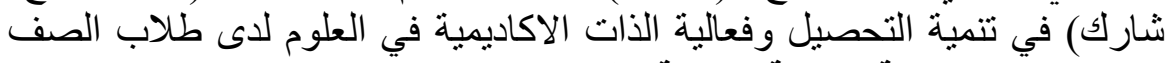

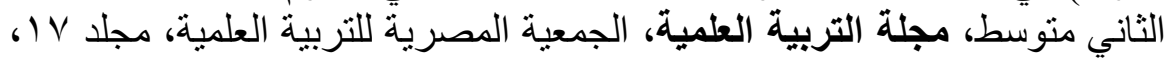

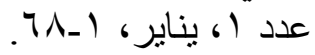


- Aroujoa. P. \& Lagos, S. (2013). Self- esteem, education and wages revisited. Journal of Economic Psychology, 34, 120132 .

- Basol, G., \& Gencel, E. (2013). Reflective thinking Scale: A validity and reliability Study. Educational Sciences: theory \& Practice, 13 (2), PP. 941- 946.

- Bandura, A (2002). Exercise of Personal and Collective efficacy in changing Societies (Eds) A Bandura. Self- efficacy in changing societies, Melbourne: Cambridge.

- Cheung, D. (2009): "Using think- aloud protocols to investigate secondary school chemistry teachers misconceptions about chemical equilibrium", The journal for teachers, researchers and other practitioners in chemistry education 10, 97- 108, DOI: 10. 1039/B 908247f .

- Dickha, O. (2005). "Teachers' in ferences about students' selfconcepts the role of dimensional comparison", Learning and Instruction, N. 15, PP. 225- 235.

- Gurol, Aysun (2011) Determining the reflective thinking skills of Pre-Service teachers in Learning and teaching Process Energy Education Science and Technology Part B: Social and Educational Studies, Vol (issue) 3, N. 3, PP: 387-402 .

- Hanna, T. (2009): "Effects of nonfiction guided interactive read- alludes and think- alludes on fourth grader's depth of content area science vocabulary knowledge and comprehension"; Dissection Abstracts International Section A: Humanities and Social Sciences, Vol 69 (8-A), PP 3090 .

- Keller, S \& Kathryn, U (2009): "With intermediate elementary students of varying levels of line graph question Interpretation Knowledge and ability: A think aloud study scenic and mathematical Humanities and Social Sciences", Dissertation Abstracts International Section, Vol 70 (1-A), A 2009. PP. 95 
- Kovalik, S and Olsen, K. (2010) : Kid's Eye View of Science: A Conceptual Integrated Approach to Teaching Science K6, first edition, U.S.A: Sage.

- Lyons, N (2010): Handbook of reflection and reflective inquiry: Mapping a Way of Knowing for professional reflective inquiry, U.S.A: Sppringer.

- Moseley, D.; Baumfield, V.; Elliott, J; Gregson, M.; Higgins, S.; Miller, J. \& Newton, D (2005): Frameworks for thinking, fifth edition, U.K: Cambridge University press.

- Song, H. \& Barbara, L (2006). "Patterns of instructionalDesign Factors Prompting Reflective Thinking in MiddleSchool and College Level Problem- Based Learning Environments". Instructional Science; An International Journal or Learning and Cognition Vol. 34 .

- Phan, Huy Phuong (2009): Exploring Students' Reflective Thinking Practice, Deep Processing Strategies, Effort, and Achievement Goal Orientations. Educational Psychology, v 29, n 3, p 297-313 May 2009. 